\title{
MITOCHONDRIAL PROTEIN TARGETING SIGNALS
}

Michelle Elisabeth Walker

A thesis presented for the degree

of

Doctor of Philosophy

University of Edinburgh

1987

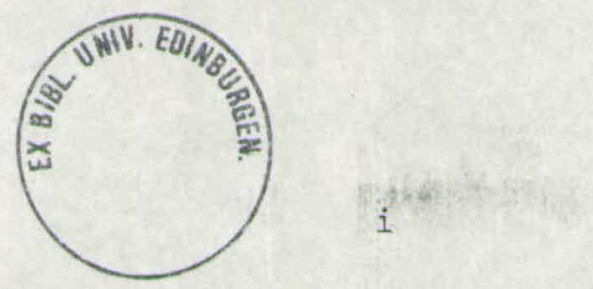


To Mum and Dad 
DECLARATION.

I hereby declare that this thesis has been composed by myself and that all the work herein is my own.

Michelle E. Walker. 


\section{ACKNOWLEDGEMENTS}

I would like to thank my supervisor Dr. Graeme Reid for his help and encouragement throughout the study.

My grateful thanks to Dr. Ian Dawes, Dr. Bruce Ward and Dr. Graeme Reid for their instruction on the finer details of word processing.

I would also like to thank the members of staff and students in the Department for making my stay here as a student a happy one. To Mr. Bill MacDonald for material supplies, to Dr. Bev Moseley, Elizabeth, Vicki, Ian and Lynn for their friendship and help.

Lastly, to Greg for his moral support and patience throughout the three years. 
TITLE

DEDICATION

DECLARATION

CHAPTER 1. GENERAL INTRODUCTION.

1.1 . Protein topogenesis.

1.3 . Import of mitochondrial proteins.

1.3.2. Cotranslational versus post

1.3.3. How mitochondria import proteins. Assembly of mitochondrial proteins. Signals which specify mitochondrial

protein transport.

1.4.1. Mitochondrial matrix targeting signals contained within the mitochondrial presequence.

1.4.2. Intramitochondrial sorting signals contained within the amino terminal regions of imported proteins.

1.4.3. The function of secondary structure within mitochondrial presequences in protein targeting.

1.5. Transport of proteins into chloroplasts. 25

1.6. Nuclear protein transport. 29

1.7. Protein export in eukaryotic and prokaryotic cells.

1.8. Aims of $\mathrm{PhD}$. study.

CHAPTER 2. MATERIALS AND METHODS.

2.1.

Strains and plasmids.

2.2 .

Culture conditions and growth media.

2.3 . Buffers and solutions.

2.4 . Isolation of DNA from $E$. coli.

2.4.1. Small scale preparation of plasmid DNA. Isolation of yeast chromosomal DNA. 
2.10.1. Restriction Digestion of DNA. 58

2.10.2. Electrophoresis of DNA. 58

2.10.3. Gene constructions. 58

2.10.4. Filling-in reaction of klenow fragment. 59

2.10.5. Removal of $3^{\prime}$ DNA extensions with $T_{\mathbf{4}}$
DNA polymerase.

$\begin{array}{ll}\text { 2.11. DNA sequencing by Dideoxychain- } & \\ & \text { termination sequencing. }\end{array}$

2.11.1. Plasmid sequencing. 60

2.11.2. Dideoxychain-termination sequencing: 61

Preparation of M13 single-stranded

DNA for sequencing templates. 61

2.11.3. Sequencing of M13 DNA template. 62

2.12. Bisulphite in vitro mutagenesis. 63

2.13. TCA extraction of proteins from $S$.
cerevisae.

2.14. Western blot analysis of proteins. 65

2.15. In vitro transcription-translation. 66

2.15.1. In vitro transcription using $E$. coli 66

2.15.3. In vitro translation. 67

2.16. Preparation of yeast mitochondria. 67

2.17. In vitro transport into isolated yeast
mitochondria.

$\begin{array}{ll}\text { 2.18. Preparation of radiolabelled mature } & \\ & \text { and precursor polypeptides. }\end{array}$

2.19. Pulse labelling of yeast proteins
in vivo.

RESULTS.

CHAPTER 3. ISOLATION AND CHARACTERISATION OF THE ATP2 GENE ENCODING BETA SUBUNIT OF YEAST ATP SYNTHASE.

3.1. Cloning and characterisation of the ATP2 gene. $\quad 73$

3.2. DNA sequencing of ATP2 gene. 76

3.3. One step disruption of the ATP2 gene. 76

3.4. In vitro transcription-translation of the ATP2 gene.

CHAPTER 4. GENE FUSION STUDIES ON THE IMPORT OF BETA SUBUNIT INTO MITOCHONDRIA IN VITRO AND IN VIVO.

4.1. In vitro transcription-translation of the chimeric ATP-DHFR genes.

4.2. In vitro import of beta subunit-DHFR hybrid proteins into yeast mitochondria. 81

4.3. Targeting of beta subunit-DHFR hybrid proteins in vivo.

4.3.1. ATP2-DHFR gene fusions.
4.3.2. Beta subunit-DHFR hybrid proteins are targeted to the mitochondria. 
CHAPTER 5. ANALYSIS OF THE STRUCTURAL REQUIREMENTS OF A TARGETING SIGNAL WITHIN THE BETA SUBUNIT PRECURSOR PROTEIN.

5.1. In vitro mutgenesis of the cloned ATP2 gene.

5.2. In vitro transport of mutant beta subunit precursor polypeptides into mitochondria.

5.3. Effect of amino acid changes on targeting of the precursor polypeptide.

CHAPTER 6. DISCUSSION. 99

REFERENCES . 
SUMMARY. 
SUMMARY.

The beta subunit of yeast ATP synthase, like most mitochondrial proteins is encoded by nuclear DNA and synthesised as a larger precursor $(56 \mathrm{kDa})$ in the cytoplasm. After posttranslational uptake the precursor is processed to the mature form $(54 \mathrm{KDa})$ by proteolytic removal of the $\mathrm{N}$ terminal presequence by a chelator sensitive endoprotease in the matrix.

The location and nature of targeting signals directing the F1-ATPase beta subunit precursor to its mitochondrial destination was investigated by mutagenesis in vitro of the cloned yeast ATP2 gene, encoding this polypeptide. Amino acid changes were made within the $\mathrm{N}$-terminal 15 residues of the presequence, by bisulphite mutagenesis (which causes $C \rightarrow T$ transitions) in a defined single stranded loop region of a heteroduplex molecule.

Gene fusion studies showed that the amino terminal 15 amino acids of beta subunit precursor are sufficient to direct mitochondrial delivery of the cytosolic protein DHFR in vitro and in vivo. Transport efficiency is improved in fusions containing 35 amino acids, where both import and proteolytic cleavage are observed. Furthermore, an internal deletion (codons 2-15) was shown to affect processing and not import of the latter fusion.

Alteration of the first targeting signal by single and multiple amino acid changes had surprisingly little effect on mitochondrial delivery of hybrid beta subunit-DHFR proteins in 
vitro or mutant beta subunit precursor polypeptides in a yeast atp2 mutant lacking beta subunit.

These results suggest that the beta subunit presequence contains two targeting signals, which are functional in mitochondrial transport. The first signal is located within the $\mathrm{N}$-terminal 15 residues of the presequence, and a second independent targeting signal located downstream, was shown to mediate transport with greater efficiency. Both signals are sufficient for rapid transport of F1 subunit in vitro and in vivo. Information required for proteolytic maturation of F1 $\beta$ subunit precursor was localised to the carboxy-terminal half of the presequence. Point mutations in the DNA coding sequence and corresponding amino acid sequence changes are tolerated in the presequence, as little effect is observed on transport in vitro and in vivo. These data suggest that secondary structure such as an amphiphilic helix, rather than the primary amino acid sequence of a mitochondrial presequence has an important function in directing protein transport to the mitochondrion. 
CHAPTER 1. GENERAL INTRODUCTION. 


\section{INTRODUCTION.}

\subsection{PROTEIN TOPOGENESIS.}

The eukaryote cell is subdivided into several compartments (or organelles) which are separated from the cytoplasm by at least one membrane. Each organelle contains a complement of proteins, enabling it to carry out a specific function. Since most proteins are synthesised on cytoplasmic ribosomes (with the exception of mitochondria and chloroplasts) the cell must possess specific transport processes which deliver the newly synthesised proteins to their correct compartment.

Recent studies have shown that proteins routed via the secretory pathway, are cotranslationally inserted into the endoplasmic reticulum whilst the protein is still growing (Blobel and Dobberstein, 1975b; Hortsch and Meyer, 1984) and subsequently sorted at the Golgi apparatus (Farquhar and Palade, 1981; Novick et al., 1981). In contrast, proteins destined for the nucleus (De Robertis, 1983), mitochondria (Gasser et al., 1982b) or chloroplasts (Ellis et al., 1980) are taken up directly in the completed form, i.e. posttranslationally.

The efficient distribution of proteins to different compartments supports the view that there must be specific sorting or topogenic information within each protein facilitating intracellular traffic. This information is, in many cases, contained in transient $\mathrm{N}$-terminal extensions that will be recognised by receptors on the target organelle (Blobel, 1980), and so initiate translocation across the membrane. Biochemical studies have demonstrated the involvement of such signal and 
receptor structures in protein transport to the endoplasmic reticulum (Hortsch and Meyer, 1984) and mitochondria (Gasser et al., 1982b). With the development of recombinant DNA technology, it has been possible to determine the localisation and nature of these structural features of a protein targeting signal.

\subsection{MITOCHONDRIAL BIOGENESIS.}

In eukaryotic cells, mitochondria multiply and grow by incorporation of newly synthesised proteins and lipids into preexisting organelles (Tzagaloff, 1975). This perpetuation of functional mitochondria requires a regulated interaction of two separate genetic systems - the nuclear and mitochondrial genomes, although little is known about the communication between of both genomes during mitochondrial biogenesis. The mitochondrion contains a small, circular genome, the size of which varies greatly from $16.6 \mathrm{~kb}$ in humans to $\sim 75 \mathrm{~kb}$ in Saccharomyces cerevisae and $>250 \mathrm{~kb}$ in plants. (Lukins et al., 1984; Breitenberger and RajBhandary, 1985). Sequence analysis from animal, fungal and plant sources (Anderson et al., 1981; Grivell, 1983; Lonsdale et al., 1984) has shown differences to exist in the coding properties of the DNA and genome organisation, although in general mitochondria have a similar genetic composition. They all encode protein components of complexes of the electron transfer chain - cytochrome oxidase (subunits 1,2 and 3 ), cytochrome b of $\mathrm{QH}_{2}$-cytochrome $c$ reductase and subunits 6 and 8 of ATPase complex, and rRNAs and tRNAs needed for mitochondrial protein synthesis. In addition to this common set of genes, unidentified reading frames (URF) encoding presumptive polypeptides of $\mathrm{NADH}-$ coenzyme $\mathrm{Q}$ reductase 
have been identified in mammalian mitochondrial DNA as well as other putative coding sequences, located within introns of genes, which encode the 'maturase' enzymes required for RNA splicing (Tzagaloff and Meyers, 1986). The presence of introns within genes in fungal mitochondrial DNA may partly account for the size disparity between the small compact vertebrate mitochondrial genome and the larger fungal mitochondrial DNA.

Most of the genetic information required for functional mitochondria is provided by nuclear genes, as the coding capacity of the mitochondrial genome is small. Over 250 different nuclear encoded proteins are synthesised in the cytoplasm and then taken up into the mitochondria (Hay et al.,1984). These imported polypeptides are not only required as components of enzyme complexes; some of them are regulatory proteins controlling mRNA processing and translation within the mitochondria (Dieckmann et al.,1984; Dieckmann and Tzagaloff, 1985). Others function in post-translational modification, such as heme addition, (Tzagaloff et al., 1986) and proteolytic removal of presequences from both mitochondrial and nuclear encoded precursor polypeptides (Pratje and Guiard, 1986). How this rate of protein import is controlled, and which signals pass from the mitochondria to the nucleus, remains a complete mystery.

Recent studies have focused on the regulation of nuclear encoded mitochondrial proteins in Saccharomyces cerevisae, in response to levels of glucose, (catabolic repression), oxygen and heme. A few examples where the molecular mechanism of this regulation has been studied are cytochrome c (Guarente and Mason, 1983), the $\alpha$ and $\beta$ subunits of $F 1$ adenosine 
triphosphatase (F1-ATPase) (Szekely and Montgomery, 1984) and cytochrome $b_{2}$ (Guiard, 1985). Whether this type of regulation also exists in higher eukaryotes is not known. There are, however, considerable tissue specific compositional differences within vertebrate mitochondria that arise from tissue specific and developmental expression of nuclear encoded mitochondrial proteins (Swanson et al., 1985).

In recent years it has become evident that the mitochondrion itself, plays an active role in the continuously operating regulation between it and the rest of the cell. This control may be at the level of expression of certain genes. Smith and coworkers (1983) found that in inbred mice, the expression of a nuclear encoded component of the major histocompatibility complex surface antigen was maternally inherited. More recently, some yeast nuclear DNA sequences were shown to be differentially expressed between respiratory competent cells $\left(p^{+}\right)$and isonuclear, respiratory deficient derivatives, which differed in their mitochondrial DNA composition. Differences were also noted between $\rho^{\bullet}$ mutants, which completely lack mitochondrial DNA, $\rho^{-}$mutants, containing largely deleted regions of mitochondrial DNA, and mit mutants, that contain small deletions or point mutations within the mitochondrial genome (Parikh et al., 1987). Since mitochondria do not seem to export any mitochondrially encoded polypeptides (Schatz and Mason, 1974), it is difficult to explain these results as to how mitochondrial DNA could control the expression of nuclear genes. Such complex interactions between mitochondria and the cell (and nucleus) may instead be mediated by the import of nuclear encoded products, such as regulatory factors and 
proteins involved in assembly of mitochondrial components, in response to the expression of the mitochondrial genome.

\subsection{IMPORT OF MITOCHONDRIAL PROTEINS.}

\subsubsection{Protein transport into the mitochondria.}

Mitochondria have the capacity to synthesise their own proteins, however, this is limited because of the small size of the genome. The majority of mitochondrial polypeptides are encoded by nuclear genes, translated on cytosolic ribosomes, and transported to the mitochondrion (Schatz and Mason, 1974; Neupert and Schatz, 1981). The specificity by which proteins are directed to the mitochondrion necessitates the recognition of certain structural features in the protein by receptor molecules on the outer surface of the mitochondria. Further sorting must take place since the mitochondrion contains two membrane compartments (the inner and outer membrane) enclosing two aqueous compartments (the matrix and inter-membrane space). Once localised, these proteins must assemble with other nuclear encoded polypeptides and those of mitochondrial origin, for enzyme activity eg. cytochrome $c$ oxidase and ATP synthase.

Our current understanding of the delivery mechanism of mitochondrial proteins has come from studies in Saccharomyces cerevisae and Neurospora crassa which trace the fate of mitochondrial precursors in vivo, and the recent development of in vitro reconstitution techniques using isolated mitochondria and radiolabelled precursor polypeptides synthesised in vitro (see reviews by Hay et al., 1984; Reid, 1985; Douglas and Takeda $1985)$. 


\subsubsection{Cotranslational versus posttranslational transport.}

Early studies suggested that protein transport into mitochondria might occur by a mechanism similar to the obligatorily cotranslational translocation of some proteins across the endoplasmic reticulum (Kellems et al., 1974, 1975). They reported that polypeptides destined for the mitochondrion became bound to the mitochondrial surface before synthesis was complete, and thus could initiate the cotranslational transport of bound nascent chains. Further support came from the observation that yeast mitochondria in vitro and in vivo were covered by cytoplasmic 80 s type ribosomes which could be dislodged by a combination of puromycin and concentrated salt, but neither alone. These features are reminiscent of the ribosome-membrane binding mediated by nascent polypeptides, associated with cytoplasmic ribosomes bound to the surface of the endoplasmic reticulum (Sabatini et al., 1966).

It has since been clearly demonstrated that there is no obligatory coupling of protein translocation across mitochondrial membranes to protein synthesis. Mitochondrial polypeptides can be synthesised in vitro from mRNA in a reticulocyte lysate, and correctly imported into isolated mitochondria after synthesis has stopped (Maccecchini et al., 1979).

Posttranslational import has also been described in vivo in yeast. Transport was found to be energy dependent and could be inhibited by uncouplers of oxidative phosphorylation, such as carbonyl cyanide m-chloro-phenylhydrazone (CCCP), or protonophores, but not by the ATP synthase inhibitor, oligomycin (Reid and Schatz, 1982a; Gasser et al., 1982b). These findings 
strongly suggest that the energy requirement for import is in the form of an electrochemical gradient across the inner membrane, rather than ATP. Yeast cells and spheroplasts labelled with [35S] methionine, were shown to accumulate cytoplasmic precursors to certain mitochondrial proteins in the presence of CCCP (Reid and Schatz, 1982a, 1982b). When CCCP was inactivated by addition of 2-mercaptoethanol, the accumulated radiolabelled precursor to F1 $\beta$ was imported and processed to the mature protein, in the subsequent chase with an excess of unlabelled methionine (Reid and Schatz, 1982b).

The presence of cytoplasmic pools of precursors in cells under physiological conditions was first detected by double-isotope pulse-chase experiments in Neurospora (Hallermeyer et al., 1977). These experiments showed a lag period between synthesis of the radiolabelled precursor and its appearance in the mitochondrial fraction. When synthesis was stopped, labelled proteins continued to appear in the fraction, indicating the posttranslational transport of previously synthesised polypeptides. No such pools could be demonstrated in yeast using similar labelling studies (Ades and Butow, 1980). Reid and Schatz (1982b) demonstrated that the size of the precursor pool in yeast was dependent upon physiological conditions. The size of the pool of accumulated F1 $\beta$ precursor could be decreased by lowering the rate of precursor synthesis with cycloheximide during pulse labelling of intact yeast cells. This was thought to reflect an increase in cotranslational transport, or a shorter time spent in the cytoplasm before uptake.

Cotranslational transport of proteins into mitochondria was 
first suggested by the properties of mitochondrially bound polysomes. Recently, direct evidence for cotranslational transport has come from in vitro synthesis of nascent chains of cytochrome $c$ subunit IV-DHFR (COX IV-DHFR) fusion protein which were shown to be rapidly transported into isolated mitochondria (Verner and Schatz, 1987). Not all mitochondrial polypeptides are synthesised on bound polysomes (at most $60 \%$ of total mRNA for mitochondrial proteins (Suissa and Schatz, 1982)), and some are synthesised exclusively on unattached polysomes. The relative importance of posttranslational import, as well as cotranslational import, is not clear and may depend on physiological factors such as metabolic status of the cell and environmental conditions.

\subsubsection{How mitochondria import proteins.}

Transport of cytoplasmically synthesised mitochondrial precursor proteins into mitochondria requires three steps:

(i) recognition and specific binding of precursors to receptors on the mitochondrial surface, from which the precursors are translocated into or across the mitochondrial membranes (Argan et al., 1983; Zwizinski et al., 1983; Riezman et al., 1983).

(ii) the energy dependent translocation of polypeptides across one or both mitochondrial membranes (Gasser et. al., 1982b).

(iii) posttranslational cleavage of precursors carrying amino terminal extensions by a chelator sensitive protease located in the matrix (Mori et. al., 1980) and inner membrane (Ono and Ito, 1984a).

Precursor proteins.

The majority of mitochondrial proteins are initially 
synthesised in the cytoplasm as precursors which are larger than the corresponding mature proteins (Neupert and Schatz, 1981). More than 20 nuclear genes encoding mitochondrial proteins have been cloned (Douglas and Takeda, 1985). DNA sequence analysis has revealed not only the amino acid sequences of the mature proteins, but also those of their cleavable presequences. Several features are shared by mitochondrial protein presequences; in particular their predominantly basic nature and high content of seryl and threonyl residues, and lack of acidic amino acids. There is no extensive sequence homology between different proteins. However, a short consensus sequence has been identified by sequence analysis of amino terminal sequences of several precursor proteins, including F1ß subunit (Yoshida et al., 1985). Proteins of the inner membrane and intermembrane space, in addition possess a hydrophobic region flanked by charged amino acid residues. For example, the 61 residue presequence of cytochrome $c_{1}$ consists of a strongly basic amino terminal region of 35 amino acids, a central region of 29 uncharged amino acids and an acidic carboxyl terminal region of seven amino acids (Sadler et al., 1984). It has been suggested (Gasser et al., 1982a; Ohashi et al., 1982) that the cytochrome $\mathrm{c}_{1}$ precursor initially translocates across both membranes, until the amino terminal part is accessible to the matrix protease (Boehni et al., 1983). Subsequent binding of protoheme IX to the transmembrane intermediate, induces a conformational change rendering the polypeptide susceptible to the second protease.

Several imported mitochondrial proteins are synthesised without amino terminal extensions; including a component of the intermembrane space - cytochrome c (Matsuura et al., 1981), a 
$70 \mathrm{kDa}$ protein of the yeast outer mitochondrial membrane (Hase et. al., 1984), the inner membrane protein ADP/ATP translocator (Zwizinski et al., 1983) and a matrix protein, 2-isopropylmalate synthase (Hampsey et al., 1983). The amino terminal presequence of the $70 \mathrm{kDa}$ protein resembles presequences of intermembrane space proteins: the basic amino terminus is followed by a stretch of uncharged residues (Hase et al., 1984). Although the precursor polypeptide has an uncleavable presequence, the targeting information for delivery to the mitochondrion is confined to the N-terminus of the protein (Hase et al., 1984).

Little is known about the conformation in which proteins are imported into mitochondria. In $N$. crassa and yeast it appears that partial or complete unfolding of the protein must occur in order to cross the mitochondrial membranes (Schleyer and Neupert, 1985; Eilers and Schatz, 1986). The protein is refolded into a different protein conformation. Further support has come from imnunological data. Korb and Neupert (1978) were able to raise antibodies specific for apocytochrome c, which suggests that cytochrome $c$ and its precursor apocytochrome $c$ must differ in conformation. The precursor and mature forms of mitochondrial malate dehydrogenase are also known to exist in different conformations (Chien and Freeman, 1986).

Receptors and translocation.

The specific nature of protein import into mitochondria suggests that there must be unique recognition between precursor polypeptides carrying an addressing signal and the mitochondrial surface by a receptor like protein. The most detailed data on import receptors has been on the receptor for apocytochrome 
c(Hennig and Neupert, 1981). Since the cytochrome polypeptide is initially synthesised as the haem-free apoprotein with a molecular weight similar to the mature protein, and since cytochrome $c$ polypeptide can be prepared from commercially available holocytochrome $c$, it can be used as the authentic precursor polypeptide. Also, conversion of apocytochrome $c$ to holocytochrome $c$ and import can be blocked by the haem analogue deuterohemin. Neupert and coworkers have shown that chemically prepared apocytochrome c competes with radiolabelled in vitro synthesised apocytochrome $c$ for a limited number of binding sites on the mitochondrial surface. Addition of holocytochrome $c$ to the in vitro system did not affect the uptake of the in vitro synthesised apocytochrome $c$, but the removal of the haem effectively inhibited uptake (Matsuura et al., 1981).

Similar, though less complete, data are available on surface receptors of proteins imported into the internal compartments, such as the ADP/ATP translocator (Argan et al., 1983), malate dehydrogenase (Chien et al., 1984) and sulphite oxidase (Ono and Ito, 1984b). Binding of ADP/ATP translocator and malate dehydrogenase to the outer membrane is protease sensitive, which suggests that the receptor is proteinaceous in nature. Also, binding is independent of energy coupling, as rat liver mitochondrial malate dehydrogenase binds at $0^{\circ} \mathrm{C}$ and in the presence of an uncoupler (CCCP). Competition studies with microsomal and outer membrane fractions showed that binding of sulphite oxidase is specific and can be inhibited with the addition of an outer membrane fraction. It is not clear how many types of mitochondrial surface receptors participate in mitochondrial protein import. 
The presequences of mitochondrial precursor polypeptides are indispensible for translocation to occur (Gasser et al., 1982a), but their mechanism of action remains unclear. It is not known whether protein translocation across mitochondrial membranes involves passage through an aqueous filled pore or through the lipid bilayer itself. Recently, chemically synthesised presequences of the mitochondrial proteins subunit IV of cytochrome c oxidase and ornithine carbamyltransferase, have been made in sufficient quantities for biophysical model studies (Roise et al., 1986; Tamm, 1986; Epand et al., 1986). Also, synthetic model peptides with repeating units of basic amino acids (arginine or lysine) and hydrophobic residues (leucine and alanine) were demonstrated to be effective inhibitors of transport of the precursors of two mitochondrial enzymes - cytochrome $\mathrm{P} 450$ (SCC) and adrenodoxin (Ito et al., 1985). The synthetic peptides did not inhibit binding of the pre-P450, but caused significant perturbation in the membrane structure. The effect on membrane structure is characteristic of peptides containing an amphipathic helix (Epand et al., 1986). Epand and coworkers showed that the synthetic peptide corresponding to the first 27 amino acids of ornithine carbamyltransferase could assume an amphiphilic helical conformation in the presence of anionic lipid, and disrupt the lipid bilayer of synthetic liposomes. This effect is enhanced by a membrane potential of the same polarity as that required for mitochondrial import (Roise et al., 1986).

Extra-mitochondrial components involved in transport.

Recent, though not strong evidence suggests that import of mitochondrial precursor polypeptides may be an "aided" process 
involving extra-mitochondrial components. A soluble cytosolic factor from yeast and reticulocytes has been identified by Ohta and Schatz (1984) which stimulates import of precursors of beta subunit of F1-ATPase and cytochrome $b_{2}$ into isolated mitochondria. It is non-dialysable, trypsin sensitive, and RNase resistant, with an apparent molecular weight of $40 \mathrm{kDa}$, as determined by gel filtration. Another cytosolic factor, from reticulocyte lysate, has been shown to be involved in the recognition and/or uptake of precursor of ornithine carbamyltransferase by heart mitochondria in vitro (Argan et al., 1983). After the translation mixture was passed through a Sephadex G25 column, reticulocyte lysate failed to support transport into isolated mitochondria. Thus import of ornithine carbamyltransferase is facilitated by the presence of a small soluble component found in the reticulocyte lysate.

A recent report suggests that an RNA moiety in reticulocyte lysate is required for import of mammalian matrix precursor proteins (Firgaira et al., 1984). It was observed that protein uptake into mitochondria was inhibited in the presence of high concentrations of RNase $(100 \mu \mathrm{g} / \mathrm{ml})$ and chelating agents which remove divalent ions. The requirement of high concentrations to degrade the RNA and instability in the presence of chelating agents are characteristic of ribonucleoproteins. The ribonuclease sensitive component is found in a $400 \mathrm{kDa}$ fraction containing the mitochondrial precursors. One of the RNA species found in reticulocyte lysate is $7 \mathrm{~S}$ RNA, a component of cytoplasmic ribonucleoprotein. It is not clear whether cytosolic factors are involved in protein import into mitochondria. They may act as a protein-RNA complex similar to the signal 
recognition particle which mediates targeting of secreted, lysosmal and membrane proteins to the endoplasmic reticulum. The cytosolic factors may bind to the precursors and trigger their correct association with the mitochondrial surface receptors.

Energy dependence of mitochondrial protein import.

Import into the mitochondrial matrix and inner membrane, unlike import into or across the outer membrane, requires an electrochemical potential, but not a proton gradient across the inner membrane (Gasser et al., 1982b; Schleyer et al., 1982). When inhibitors of oxidative phosphorylation are added (CCCP - a proton ionophore, and valinomycin, a potassium ionophore which reduce the electrochemical potential difference across the membrane), import but not binding is inhibited. However, in the presence of nigercin (an ionophore which exchanges protons for potassium, so reducing the $\mathrm{pH}$ gradient across the membrane) there is no effect (Schleyer et al., 1982; Ono and Ito, 1984a).

The $\Delta \mu \mathrm{H}^{+}$necessary for protein translocation is probably smaller than that necessary for ATP synthesis, as $\rho^{-}$mutants of yeast can import proteins into their mitochondria, even though these mitochondria lack a funtional ATPase complex as well as a respiratory chain. A small electrical potential may be generated via the adenine nucleotide translocator (Klingenberg and Rottenberg, 1977).

Protein transport across several biological membranes, has been found to require ATP. For example, protein translocation across the bacterial plasma membrane requires both ATP and an electrochemical potential across the membrane (Geller et al., 1986; Chen and Tai, 1985; Yamane et al., 1987). ATP appears to be the only energy source needed for transport across the 
endoplasmic reticulum (Rothblatt and Meyer, 1986; Mueckler and Lodisch, 1986) or into chloroplasts (Grossman et al., 1980). Mitochondria were thought to be the exception. The demonstration that import could be driven by a $\mathrm{K}^{+}$-diffusion potential across the membrane (Pfanner and Neupert, 1985), led to the view that the only energy requirement was the electrical component $(\Delta \psi)$ of the proton motive force. However, high energy phosphate compounds (eg ATP) have been subsequently demonstrated also to be necessary. (Pfanner and Neupert, 1986). These experiments showed that in the presence of oligomycin, a membrane potential was not sufficient for import of F1 $\beta$ subunit in an ATP dependent reticulocyte lysate (containing radiolabelled precursor proteins) and mitochondria. Addition of ATP and GTP restored import. However, the import of F1 subunit was completely inhibited, even in the presence of ATP when the membrane potential was destroyed.

The nature of energy requirements for protein translocation were suggested to be different for polypeptides which were an integral part of the inner membrane and those which must be transported through the inner membrane to the matrix (Pfanner and Neupert, 1985; Schleyer and Neupert, 1985). These studies showed that the insertion of ADP/ATP translocator into the mitochondrial inner membrane required a membrane potential across the inner membrane (Pfanner and Neupert, 1985). In the case of F1B subunit, which is located in the matrix, only the initial translocation of its amino terminus into the inner membrane was dependent on a membrane potential (Schleyer and Neupert, 1985). It was possible to demonstrate that the amino terminus and carboxy terminus of the precursor polypeptide were 
Figure 1.1.

PROPOSED SEQUENCE OF EVENTS DURING IMPORT OF A POLYPEPTIDE INTO THE MITOCHONDRIAL MATRIX (Filers et al., 1987).

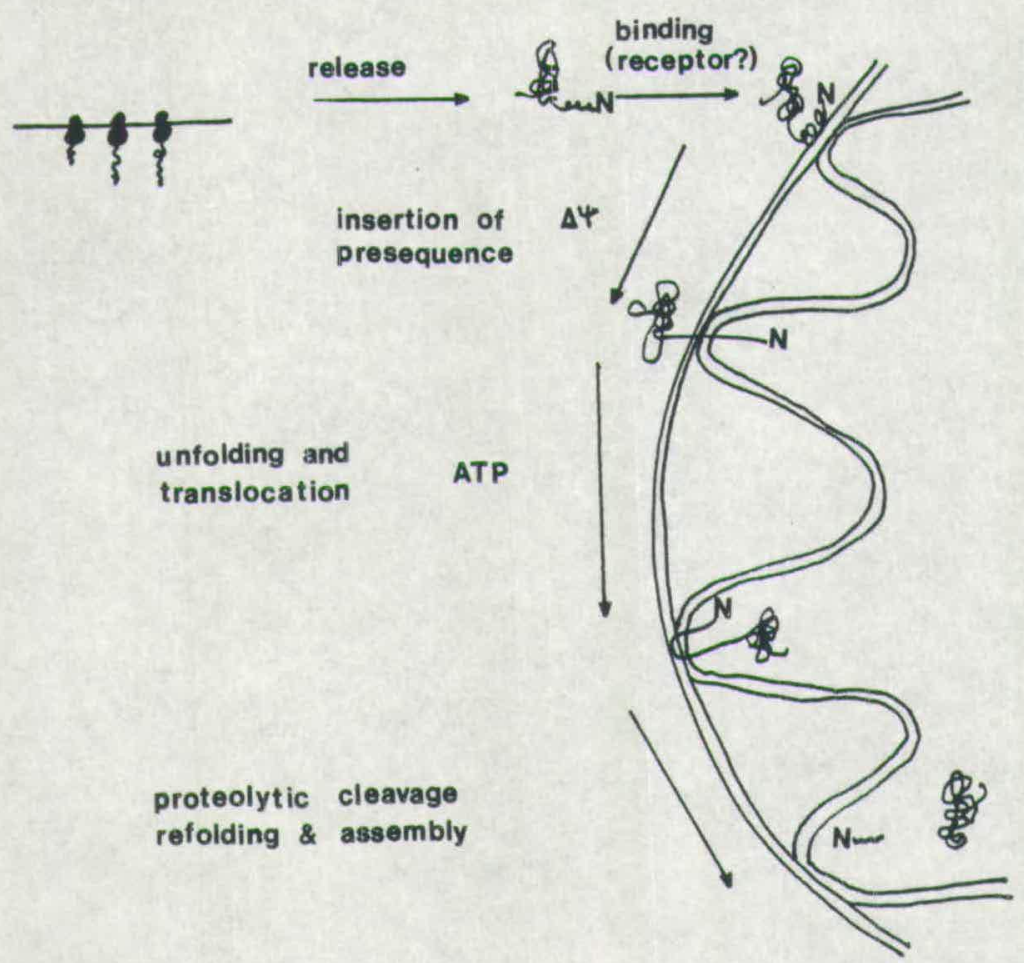

A polypeptide destined to be imported into the mitochondrial matrix is initially made as a precursor which usually carries an amino-terminal extension. The completed precursor protein binds to a receptor on the cytoplasmic face of the mitochondrial outer membrane. The formation of an amphiphilic alpha helix within the presequence at the membrane surface, may allow import to occur via contact sites between the two mitochondrial membranes (Schleyer and Neupert, 1985). This process is independent of protein synthesis, but requires an electrochemical potential across the inner membrane, for insertion and translocation of the first few amino acids of the presequence. The mature protein is translocated in an energy-independent manner, possibly requiring ATP for the unfolding and translocation of the protein. Upon import into the matrix, the transient amino-terminal extension is precisely cleaved by a soluble protease in the matrix space, where upon the polypeptide assumes the correct conformational form of the mature protein. 
accessible to the matrix protease and exogenous proteinase $\mathrm{K}$ respectively, located on opposite sides of the mitochondrial inner membrane (Schleyer and Neupert, 1985). This translocation intermediate simultaneously spanned both the inner and outer membranes, in which the F1 $\beta$ subunit precursor must be partially unfolded.

Recent studies have shown that protein import into yeast mitochondria requires not only an energised inner membrane, but also ATP outside the inner membrane (Eilers et al., 1987; Chen and Douglas, 1987). In a simplified system containing only yeast mitochondria, energy sources and purified precursor protein (cytochrome c oxidase subunit IV prepiece fused to mouse dihydrofolate reductase), ATP was shown to support import even when the proton translocating mitochondrial ATPase and adenine nucleotide transport was blocked. The ability of GTP, but not non-hydrolysable ATP analogs to replace ATP, strongly suggested that ATP exerts its effect by hydrolysis of a phosphodiester bond (Eilers et al., 1987; Chen and Douglas, 1987). This process is thought to act on the precursor at the site of translocation, possibly by unfolding and refolding the mature protein during translocation. Figure 1.1 represents a model of the energy requiring steps during import (Eilers et al., 1987).

\section{Proteolytic maturation of mitochondrial proteins.}

The proteolytic processing of some mitochondrial proteins during import involves one or more distinct proteases found in yeast (McAda and Douglas, 1982; Boehni et al., 1983; Daum et al., 1982); rat liver (Miura et al., 1982; 1986; Ono and Ito, 1984a) and Neurospora crassa (Schmidt et al., 1984). This complex process is surprisingly similar between species although 
Fiqure 1.2.

PROPOSED PATHWAY FOR MATURATION OF CYTOCHROME D 2 AND CYTOCHROME $\underline{c}_{1}$ IN YEAST (TWO STEP PATHUAY) (Gasser et al., $1982 \mathrm{a}$ )

1.

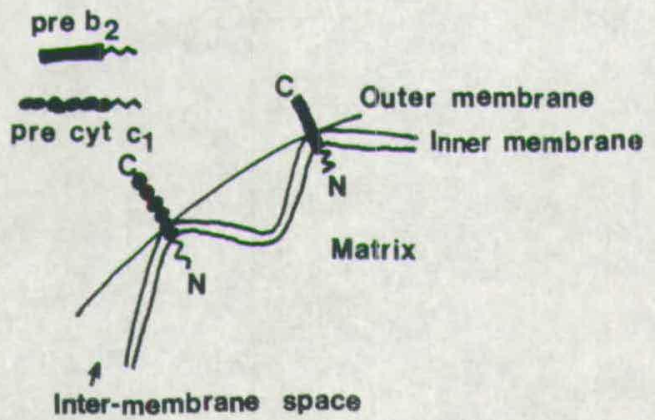

2.

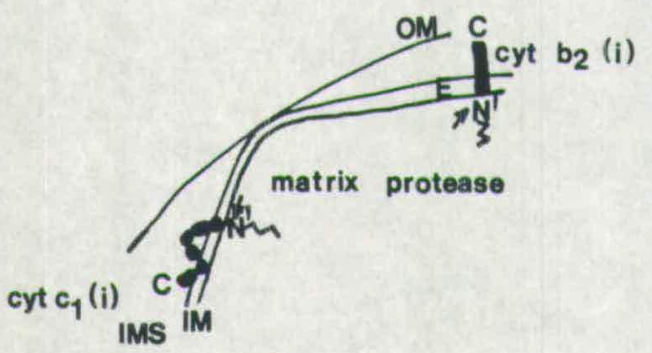

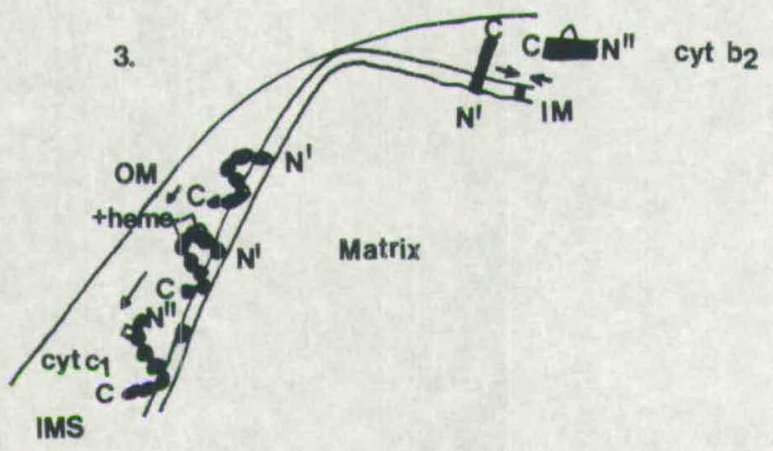

The cytochromes are synthesised on cytoplasmic ribosomes as larger precursors, and bind to receptors on the outer membrane of the mitochondrion before being translocated across both membranes. The first proteolytic cleavage by the matrix endoprotease generates a new amino terminus $\left(N^{\prime}\right)$ and a transmembrane intermediate. In the case of cytochrome $c_{1}$, the second proteolytic cleavage can only occur when the apocytochrome contains the prosthetic group heme. The second proteolytic cleavage of the membrane bound intermediates of both cytochromes, is thought to occur close to the outer face of the inner membrane and generates the amino terminus of the mature protein ( $N M)$. Cytochrome $b_{2}$ is released into the intermembrane space, whilst cytochrome $c_{1}$ remains attached to the inner membrane via its hydrophobic carboxyl tail. 
differences exist in the patterns of proteolytic maturation depending on the particular mitochondrial protein and its submitochondrial location.

The best characterised mitochondrial protein is a matrix located endoprotease, which has been partly purified from yeast (McAda and Douglas, 1982; Boehni et al., 1983) and rat liver (Miura et al., 1982; 1986). It is insensitive to serine protease inhibitors (TPCK, TLCK, PMSF, and DFP) and microbial protease inhibitors (such as pepstatin and leupeptin) but can be inhibited by metal chelators such as EDTA and 1,10-phenanthroline. The chelator inactivated enzyme can be reactivated by divalent ions $\mathrm{Zn}^{+}, \mathrm{Mn}^{+}$, and $\mathrm{Co}^{*}$. The enzyme cleaves a variety of mitochondrial precursors (such as $\alpha, \beta$, and $\gamma$ subunits of F1-ATPase, cytochrome $c$ oxidase subunit $v$, and citrate synthase) generating the mature amino terminus, but fails to cleave non-mitochondrial proteins or denatured proteins. It is itself imported, since it is still present in mitochondria of a rho- mutant lacking mitochondrial protein synthesis (Boehni et al., 1983).

Gasser and coworkers (1982a) and Daum et al., (1982) have reported the presence of a protease associated with the yeast mitochondrial inner membrane, responsible for converting intermediate forms of some proteins destined for the intermembrane space or outer surface of the inner membrane, to their mature forms. Together with the matrix endoprotease, it participates in the import pathways of several mitochondrial proteins destined for the inner membrane and intermembrane space (see figures 1.1 and 1.2 ). Temperature sensitive yeast mutants have been recently isolated, which are blocked in the processing 
of matrix proteins (Yaffe et al., 1985) and in the second proteolytic step of cytochrome $b_{2}$ found in the intermembrane space (Pratje and Guiard, 1986). Surprisingly, this latter also defective in proteolytic processing of a subunit II of cytochrome coxidase, a mitochondrially-encoded protein. Another distinct protease found in the inner membrane has been shown to participate in the import of precursor polypeptide for sulphite oxidase into the intermembrane space of rat liver mitochondria (Ono and Ito, 1984a). The processing enzyme is firmly associated with the inner membrane and is not released by $0.9 \% \mathrm{NaCl}$. Since the processing activity is found in mitoplasts and only slight activity can be detected in inner membrane vesicles which were inverted by sonication, the protease seems to be localised on the outer surface of the inner membrane. It is a metalloenzyme, since the processing activity is strongly inhibited by some metal chelators including GTP, EDTA and Zincon, but not the serine protease inhibitors.

In Neurospora crassa, the two step processing of subunit 9 (proteolipid) of F1ATPase, occurs by a metalloenzyme located in the matrix (Schmidt et al., 1984). The activity of the processing peptidase is dependent on the the presence of divalent metal ions $\left(\mathrm{Mn}^{+}\right)$and can be inhibited by PMSF, TPCK, TLCK, EGTA or aprotinin. The addition of Triton X-100 (1\%) leads to a three fold stimulation of enzyme activity. The detergent may mimic the membrane environment for the precursor, thus facilitating the action of the processing peptidase.

In addition to the mitochondrial proteases involved in mitochondrial biogenesis, there are several proteases found in yeast which are involved in the degradation of mitochondrial 
proteins (Viard and Stahl, 1985). The presence of chelator sensitive endopeptidases and an amino peptidase in the mitochondrial matrix (Yasuhara and Ohashi, 1987) suggests that the mitochondrion has the capacity to degrade proteins completely to amino acids. These proteases and a previously reported ATP dependent protease, which acts on proteins with abnormal conformations (Desautes and Goldberg, 1982) are thought to be responsible for protein turnover in the inner membrane and matrix.

\subsubsection{Assembly of mitochondrial proteins.}

The final step in the transport pathway is the assembly of processed proteins into functional forms within the mitochondrion. Assembly can be considered to be:

(i) the localisation of individual polypeptides in their final submitochondrial compartment and correct orientation, or

(ii) the formation of holooligomers by certain proteins to become functionally active, or

(iii) the association of mitochondrial and nuclear encoded proteins to form heterooligomeric complexes (such as ATP synthase, cytochrome $c$ oxidase, and ubiquinol:cytochrome $c$ reductase).

The question of assembly has been addressed by only a few investigators, as it is difficult to demonstrate that in vitro experiments accurately represent what is found in vivo.

Subfractionation of yeast mitochondria after in vitro import showed that imported $F 1 \beta$ subunit and cytochrome $b_{2}$ proteins were properly localised in the mitochondrial matrix and intermembrane space respectively (Gasser et al., 1982a). 
Proportions of cytochrome $b_{2}$ and isopropylmalate synthase, however, were recovered in the membrane fraction and may represent import intermediates. Further evidence that in vitro experiments were representative of transport in vivo, was the exclusive recovery of the membrane proteins cytochrome $c_{1}$ and cytochrome $c$ oxidase subunit $\mathrm{V}$ in the membrane fractions.

A recent study on the in vitro import of cytochrome $\mathrm{P} 450$ (SCC) precursor polypeptide in bovine adrenal cortex mitochondria (Ou et al., 1986), demonstrated that the imported protein was correctly assembled and in the same conformation as the native $\mathrm{P} 45 \mathrm{O}(\mathrm{SCC})$. Trypsin digestion of sonicated mitochondria after in vitro import and processing of the precursor resulted in several fragments including the $29 \mathrm{kDa}$ and $26 \mathrm{kDa}$ fragments, corresponding to those detected in the tryptic treatment of native $\mathrm{P} 45 \mathrm{O}(\mathrm{SCC})$. In addition to the two fragments, another major fragment $(40 \mathrm{kDa})$ was also produced, which was not detected in the tryptic treatments of the native protein. These experiments concluded that the majority of in vitro imported $\mathrm{P} 450$ (SCC) protein was tightly associated with the inner membrane, and in the same conformation as native $\mathrm{P} 45 \mathrm{O}$ (SCC).

Aggregation of precursor polypeptides during import in vitro has been observed for the three largest subunits of yeast F1-ATPase (Lewin and Norman, 1983); mitochondrial aspartate aminotransferase (Behra and Christen, 1986) and beta subunit of F1-ATPase (Chen and Douglas, 1987). These mitochondrial proteins were found to exist as either homodimers, homo- or heterooligomers and high Mr complexes.

The proper assembly of newly imported subunits into complex holoenzymes has not been demonstrated in mitochondria. 


\subsection{SIGNALS WHICH SPECIFY MITOCHONDRIAL PROTEIN TRANSPORT}

\subsubsection{Mitochondrial matrix targeting signals contained within the}

mitochondrial presequence.

The majority of mitochondrial proteins contain a cleavable presequence, which is removed during import. The possible role of these presequences in mitochondrial transport, has been addressed by gene fusion studies. These studies have demonstrated that mitochondrial presequences are composed of distinct functional regions (Hurt and van Loon, 1986). In many instances, the amino terminal region contains information for targeting the precursor to the mitochondrial matrix space. For example the presequences of cytochrome $c$ oxidase subunit IV (Hurt et al., 1984, 1985a) and ornithine transcarbamylase (Horwich et al., 1985a) are sufficient to direct attached mouse dihydrofolate reductase (DHFR), a cytosolic protein, to the mitochondrial matrix. As little as 9 to 12 amino acid residues are sufficient to constitute a matrix targeting signal (Hurt et al., 1985a; Keng et al., 1986). The yeast $70 \mathrm{kDa}$ protein of the mitochondrial outer membrane, which does not possess a cleavable presequence, was also shown to contain information required for correct targeting and localisation within the $\mathrm{N}$-terminal 41 amino acids (Hase et al., 1984). Gene fusions with the amino terminus of the $70 \mathrm{kDa}$ protein attached to $E$. coli beta-galactosidase, demonstrated that there were two types of topogenic information contained in the uncleavable presequence. The first 21 residues defined a matrix targeting signal, which by itself, could direct the attached protein to the 
mitochondrial matrix in vivo. Outer membrane proteins thus possess a matrix targeting signal, in common with imported mitochondrial proteins which are localised within the mitochondrion.

\subsubsection{Intra mitochondrial sorting signals contained within the amino} terminal regions of imported proteins.

Evidence from gene fusion studies suggest that information, other than the matrix targeting signal within the presequence are required for intramitochondrial sorting. For example, presequences of two inner membrane proteins cytochrome $c_{1}$ and FeS protein of the $b_{1}$ complex, were shown to direct mature subunit IV of cytochrome c oxidase to the intermembrane space (van Loon and Schatz, 1987). These inner membrane proteins are exposed to the intermembrane space in situ. Similarly, the first 41 residues of the yeast $70 \mathrm{kDa}$ outer membrane protein transports $E$. coli beta-galactosidase and anchors it to the outer membrane in the correct orientation (Hase et al., 1984).

This sorting of imported proteins requires two functionally distinct signals within the presequence: a matrix targeting signal (found in all imported proteins), followed by an intramitochondrial sorting signal, required for delivery to the inner membrane, intermembrane space and outer membrane. In the $70 \mathrm{kDa}$ yeast outer membrane protein, the matrix targeting signal located within the first 12 amino acids, targets proteins to the mitochondrion. Hurt and coworkers (1985a) showed that this 'signal' when attached to DHFR or mature cytochrome $c$ oxidase subunit IV, could direct transport across the mitochondrial inner membrane in vitro and in vivo. A stretch of 28 uncharged residues flanked on both sides by basic residues (Hase et al., 
1983), acts as a sorting signal and prevents passage across the outer membrane. If this transmembrane signal is partially removed (for example as few as two residues) anchorage is abolished and the protein is mislocalised to the matrix (Hase et al., 1984).

Similar intramitochondrial sorting information was observed in cytochrome $c_{1}$, a mitochondrial inner membrane protein which protrudes into the intermembrane space (van Loon et al., 1986, 1987). These experiments showed that the complete presequence attached to DHFR directed transport to the intermembrane space and was accompanied by a two step proteolytic removal of the presequence. The cytochrome $c_{1}$ presequence resembled the situation found with ADP/ATP translocator (Adrian et al., 1986) and the yeast $70 \mathrm{kDa}$ protein (Hase et al.,1984) - that is, a matrix targeting signal followed by a stop transfer sequence. An alternative function of the second signal has been suggested for iron-sulphur protein of the $b_{1}$ complex. Here, it acts as a signal for reexportation of the protein from the matrix. The precursor is translocated completely into the matrix, proteolytically modified and afterwards exported back into the intermembrane space (Hartl et al.,1986; van Loon and Schatz, 1987).

It has been suggested that the information for directing proteins to their correct intramitochondrial location is a linearly arranged set of discrete signals at the amino terminus of the imported mitochondrial protein (Hurt and van Loon, 1986).

1.4.3. The function of secondary structure within mitochondrial presequences in protein targeting. 
Most mitochondrial targeting sequences are rich in basic and hydroxylated amino acids and devoid of acidic amino acids or extended hydrophobic stretchss (Reid, 1985). In contrast, the signal sequence of secreted proteins (both eukaryotic and prokaryotic) is composed of a short positively charged $\mathrm{N}$ terminal region, a long central hydrophobic core and a polar C terminal region (von Heijne, 1985). Both types of topogenic sequences are variable in length.

The possibility of a common structure found in mitochondrial presequences which would function in transport, was indicated in a study of the properties of a synthetic peptide (Roise et al., 1986). The peptide representing the 25 residue presequence of cytochrome $c$ oxidase subunit IV was capable of inserting into phospholipid bilayers. Circular dichroic measurements showed that the synthetic signal had no detectable structure in aqueous solution, but assumed a helical conformation in the presence of a detergent micelle. A computer analysis of mitochondrial and cytoplasmic proteins predicted that most, if not all mitochondrial presequences could assume an amphiphilic alpha helical conformation in a lipid environment (von Heijne, 1986). Such amphiphilic helices possess a polar face of positively charged amino acids and a non polar face of hydrophobic residues, which may mediate translocation across the membranes (Roise et al., 1986).

In an attempt to determine whether secondary structure, in particular a charged amphipathic domain, function as a targeting signal, artifical presequences were constructed (Allison and Schatz, 1986). These peptides contained either arginine, serine and leucine or arginine, glutamine and serine, in a ratio 
representative of natural presequences. When fused to truncated cytochrome $c$ oxidase subunit IV lacking its presequence, only those with arginine, serine and leucine residues were found to direct transport in vitro and in vivo. The same experiments demonstrated that an amphipathic helix assumed by a mitochondrial presequences was not requisite for import, and secondary structures could not be predicted with certainty. One synthetic peptide predicted as an $\alpha$ helix was found to be present as a beta sheet both in aqueous solution and in the presence of detergent micelles (Schatz, 1987). This signal does not depend on the primary structure but on an overall ratio of basic amino acids, hydrophobic and hydrophilic residues. Although amphiphilicity of the presequence may be important for protein import, amphiphilic $\alpha$ helices are quite frequent in cytosolic proteins. They function in tertiary folding, by orientating hydrophobic residues to the protein interior and charged residues towards the surface. Such amphiphilic sequences were found to occur in DHFR, a cytosolic protein, but were only active as a transport signal if placed in front of a passenger protein (Hurt and Schatz, 1987). These results suggest that in mitochondrial proteins, targeting signals may be functional only when exposed on the protein surface, and are thought to act and fold independently of the mature protein (Hurt and van Loon, 1986; Eilers and Schatz, 1986).

\subsection{TRANSPORT OF PROTEINS INTO CHLOROPLASTS.}

Chloroplasts like mitochondria, contain their own DNA which codes for only a limited number of proteins, as well as all the organelle RNAs, a few ribosomal proteins and elongation factors. 
The replication and transcription machinery, and the majority of enzymes of the biosynthetic pathways are derived from nuclear genes (Schmidt and Mishkind, 1986). Chloroplast proteins encoded by the nucleus are synthesised as larger molecular weight precursors, with an amino terminal sequence, or transit peptide, which is proteolytically removed by at least two proteolytic steps during or after posttranslational transport into the chloroplast. The precursor protein must be transported to its final location that is either the envelope membrane, the stroma, the thylakoid membrane or the lumen.

The mechanism of transport of thylakoid and stromal proteins is thought to be similar to mitochondrial matrix proteins, as an energy dependent process. In contrast to posttranslational transport of proteins into the bacterial plasma membrane (Chen and Tai, 1985) and mitochondria (Eilers and Schatz, 1987) which require both ATP and an electrochemical gradient, chloroplast transport was shown only to require ATP (Grossman et al., 1980). It is not known how the ATP derived energy is coupled to transport across the envelope membranes.

Transport is initiated by recognition and energy independent binding of chloroplast precursor proteins to proteinaceous receptors on the cytosolic surface of the outer envelope membrane. As in mitochondria, it is probable that more than one class of receptor exists (Schmidt and Mishkind, 1986). protein

Chloroplast,maturation occurs during or after transport

into the organelle. Several proteases have been characterised, including a soluble transit peptidase found in pea stroma (Robinson and Ellis, 1984) and from Chlamydomonas (Mishkind et al., 1985). The pea enzyme is a metalloprotease similar to the 
matrix protease (Boehni et al.,1983), whereas the algal protease is inhibited by sulphydryl compounds. The pea transit peptidase has been reported to mature precursors of wheat and barley plastocyanin and ferredoxin NADP oxidoreductase (Robinson and Ellis, 1984). However, the two step maturation of plastocyanin (a thylakoid protein) is similar to that of the mitochondrial proteins cytochrome $b_{2}$ and cytochrome $c_{1}$ (Gasser et al., 1982a; Daum et al., 1982). The initial cleavage is performed by a soluble metalloprotease (Robinson and Ellis, 1984) and the second step by a thylakoid processing peptidase (Hagman et al., 1986).

A number of precursor proteins have been studied, including the small subunit of ribulose bis-phosphate carboxylase (RuBPC), plastocyanin and ferredoxin. The most characterised of these nuclear encoded proteins, the RuBPC small subunit, has been sequenced from several plant species. Comparison of amino acid sequences have shown the mature protein to be evolutionarily conserved and the transit peptide to contain only a few regions of homology (Mishkind et al., 1985). Although chloroplast transit peptides have limited sequence homology, they resemble mitochondrial presequences in net positive charge, lack acidic amino acids and extended hydrophobic stretches (von Heijne, 1986) and show the same tendency to form amphiphilic helices (Roise et al., 1986).

In addition, a structural framework of amino acids is conserved in transit peptides of thylakoid proteins such as the light harvesting complex proteins (LHCP II) and ferredoxin, and stromal proteins; small subunit of RuBPC and plastocyanin. Sequence comparison of the above proteins has identified three 
blocks of amino acid homology, which lie at the beginning, middle and end of the transit sequence, and are separated by differing lengths of unconserved sequence (Karlin-Neumann and Tobin, 1986). The observed hydrophobic character and conserved sequences (eg. GGRV) are thought to be essential and sufficient for recognition, binding, uptake and maturation of the precursor protein. Such comparable amino acid sequence homologies have not been observed in mitochondrial proteins.

It is of interest that several chloroplast-encoded proteins of the thylakoid membrane are made as larger precursors with $\mathrm{N}$-terminal extensions. These transient sequences are suggested to mediate membrane translocation between connecting stromal and granal lamellae. For example the larger precursor polypeptides of the thylakoid membrane proteins $32 \mathrm{kDa}$ and D protein of Photosystem II (PSII) are synthesised on membrane bound chloroplast ribosomes in the stromal lamella. Matto and Edelman (1987) demonstrated by double-isotope pulse-label studies in Spirodela oligorrhiza, that synthesis and processing of the herbicide binding protein $35.5 \mathrm{kDa}$ precursor occurred in the stromal lamellae. Posttranslational modification by palmitoylation was associated with the granal lamellae, and was suggested to be required for relocation of the protein to the site of PS II function ie the grana.

The similarity in protein transport for chloroplast and mitochondrial proteins has been highlighted by gene fusion studies (Hurt et al., 1986 a, b). In these experiments the first 31 amino acids of the transit peptide of small subunit of RuBPC was fused to DHFR, a cytosolic protein, and cytochrome $c$ oxiase subunit IV, an imported mitochondrial protein, from which the 
presequence had been removed. The small subunit-DHFR hybrid protein was compared with a hybrid containing the mitochondrial subunit IV presequence for transport in vitro and in vivo. RuBPC small subunit transit peptide could direct DHFR to the mitochondrion but less efficiently than the mitochondrial presequence. The chloroplast transit peptide was also shown to direct mature subunit IV of cytochrome c oxidase to the correct mitochondrial location in vivo. The hybrid protein when expressed in a yeast mutant deficient in subunit IV protein and cytochrome c oxidase activity, could partially restore growth of the mutant on a non fermentable carbon source. Conversely, a mitochondrial presequence could direct both chloroplast- and nuclear-encoded large subunit and small subunit into isolated yeast mitochondria. These results indicate a functional similarity between mitochondria and chloroplasts, although each possess a distinct protein composition. Therefore sorting must either require organelle specific targeting signals to discriminate between chloroplasts and mitochondria, or more likely, a selective degradation pathway to remove mislocalised proteins.

\subsection{NUCLEAR PROTEIN TRANSPORT.}

The nucleus contains a distinct set of proteins which are synthesised in the cytoplasm and subsequently imported, as with mitochondria, but in the completed form. To date, little is known about the nucleocytoplasmic sorting of proteins which must take place, however pore complexes embedded in the nuclear envelope are thought to have a role in this traffic. The pores allow the passage of electrolytes and small molecules, in 
addition to permitting selective entry of macromolecules larger than the pore orifice.

Early microinjection experiments with oocytes using labelled proteins (Bonner, $1975 \mathrm{a}, \mathrm{b}$ ) or dextrans of different size (Paine et al., 1975) showed that the diameter of the nuclear pore was $45 \AA$. The pore complex is thought to act as a molecular sieve, allowing proteins smaller than the orifice to enter the nucleus by diffusion, but only those of nuclear origin are retained (Bonner, 1975b). Passive diffusion alone, does not explain the rapid accumulation of very large nuclear proteins such as nucleoplasmin (Dingwall et al., 1982), whilst small non-nuclear proteins such as BSA only enter slowly or not at all. It is likely that other factors may influence nuclear envelope permeability, in the uptake of nuclear proteins, as seen in RNA binding proteins. In the case of those binding to U-snRNA, the presence of the RNA enables the protein to migrate to the nucleus, whereas, the RNA free form is excluded from the nucleus (Zeller et al., 1983). A different effect is observed with transcription factor IIIA, a $40 \mathrm{kDa}$ protein known to bind to Xenopus 5S genes and 5S RNA. Here, the protein when bound to 5S RNA is excluded from the nucleus as a cytoplasmic 7S RNA particle. The free protein must be able to enter the nucleus, as it is known to bind to $5 \mathrm{~S}$ genes. The distribution of such proteins is clearly affected by RNA binding.

Nuclear proteins are now thought to contain specific structural features within the mature protein which mediate passage through the pore complex. This differs from the cotranslational transport of secretory proteins and the posttranslational uptake of mitochondrial and chloroplast 
proteins, where the precursor polypeptide is proteolytically matured during or after transport. Experimental evidence for a 'nuclear location signal' residing in a discrete polypeptide domain, was shown by microinjection of Xenopus oocytes with nucleoplasmin, a large acidic pentameric protein found in the nucleus (Dingwall et al., 1982). The monomer contains two protease cleavable domains - a tail and core region. Only the detached tails were rapidly accumulated in the nucleus, and could direct the core pentamer to the nucleus. The core protein itself failed to enter the nucleus, and conversely, when directly injected into the nucleus it did not pass into the cytoplasm. These results indicate the requirement of the C-terminal fragment for entry, but not retention within the nucleus. During the selective entry of nuclear proteins, this 'signal' is suggested to be recognised by some component of the nuclear envelope, such as the pore complex, which as a result dilates and thereby facilitates uptake (Dingwall, 1985).

Several recent findings have indicated that a simple primary sequence may be only required as a signal for entry. Hall and coworkers (1984) demonstrated by gene fusions, that as few as the amino-terminal 13 residues of the yeast MAT $\propto 2$ protein were sufficient to transport a MAT $\alpha 2$-beta galactosidase hybrid protein to the nucleus. The amino termini of the yeast GAL 4 (74 amino acids) and L3 (21 amino acids) proteins were shown to transport similar beta galactosidase hybrid proteins to the nucleus (Silver et al., 1984; Moreland et al., 1985). Sequence comparison of several nuclear proteins including histones H2B, H2A, and H4, MAT $\propto 1$ (Hall et al., 1984), ribosomal protein L3 (Moreland et al., 1985) and nucleoplasmin (Dingwall 
et al., 1987) have identified a motif of a proline and /or alanine residue flanked by several basic lysine and arginine residues. This consensus sequence may represent a nuclear location signal.

More detailed work has been obtained using nuclear location studies in viruses, in particular simian virus 40 (SV4O) large tumour (T) antigen. A spontaneous mutant of SV4O-adenovirus 7 hybrid virus (PARA (cT)) was described by Butel and coworkers (1969) that failed to accumulate large $\mathrm{T}$ antigen in the nucleus. Sequence comparison of a comparable SV4O (cT) mutant and wild type SV4O virus identified the nuclear location signal as a highly basic stretch of amino acids (pro lys lys lys arg lys val) containing five consecutive positively charged amino acids (Langford and Butel, 1984). Furthermore, a substitution of lys 128 by asparagine could be correlated to the transport defect in the SV4O (cT) mutant. Subsequent studies using synthetic peptides containing the SV4O $\mathrm{T}$ antigen consensus sequence conjugated to carrier proteins, have shown that the rate of transport to be dependent on the length of targeting sequence (Langford et al., 1986). Interestingly, the polyoma virus $\mathrm{T}$ antigen contains two sequences involved in nuclear transport (Richardson et al, 1986). These sequences (pro lys lyszsala arg glu asp) and (val ser arg lysiga arg pro arg) bear some resemblance to the SV4O large $\mathrm{T}$ signal in overall basic character, and function as individual sequences in directing pyruvate kinase, a cytosolic protein to the nucleus.

These experiments suggest that secondary structure and charge rather than primary amino acid sequence, are of importance in determining signal recognition. With the recent 
development of model systems in vitro, using isolated nuclear envelope vesicles (Reidel and Fasold, 1987), it should be possible to study the structures and mechanisms involved in nuclear protein transport.

\subsection{PROTEIN EXPORT IN EUKARYOTIC AND PROKARYOTIC CELLS.}

Secretory and membrane proteins of prokaryotic and eukaryotic cells are synthesised with amino terminal signal sequences that enable them to cross a membrane or integrate into it (Hortsch and Meyer, 1984; Wickner and Lodish, 1985). These signal sequences are structurally and functionally similar, however, there is little sequence homology (von Heijne, 1983). In contrast to mitochondrial presequences, the essential features of signal sequences are one or more positively charged residues at the amino terminus, followed by a continuous stretch of 8 or more hydrophobic or neutral amino acids, which are predicted to form an alpha helix or extended thread, and a signal peptidase cleavage site (of polar residues) located in a beta turn (Gascuel and Danchin, 1986). The crucial role of the hydrophobic region has been demonstrated in mutational analysis of several exported bacterial proteins. Disruption of this region by deletion or insertion of basic residues leads to a block in export (Emr and Silhavy, 1982, 1983). In certain cases, the signal sequence alone, does not suffice for protein insertion. Kuhn and workers (1986) showed that the basic carboxy terminal domain of M13 procoat was essential for its membrane assembly. As with mitochondrial proteins, signal sequences of secretory proteins are exchangeable (Takahara et al., 1985), the 
information for cellular sorting contained within the sequence (Guan and Rose, 1984). Furthermore, unrelated sequences have been shown to function as signal sequences, in the secretion of yeast invertase (Kaiser et al , 1987). About 20\% of sequences derived at random from human DNA, were recognised as export signals, which suggests that an overall structural property must be recognised by the transport machinery.

Protein export does not occur spontaneously but requires cellular export machinery for selective and efficient localisation of proteins to a particular cellular compartment. In Saccharomyces cerevisae, temperature sensitive mutants defective in distinct steps in the secretory pathway have demonstrated clearly the role and order of events in the pathway, that is from the endoplasmic reticulum (ER) to the Golgi, to the vesicles and finally cell surface (Schekman, 1982). In addition trafficking of proteins to other compartments, such as the yeast vacuole, share the secretory pathway (Stevens et al., 1982). Since sec mutants blocked in the early stages but not the late stages of secretion prevent vacuole biogenesis, a branch point must exist at the Golgi. The common gene products of the secretory pathway appear to be also involved in endocytosis (Riezman, 1985). In eukaryotic cells, the 'signal hypothesis' was proposed (Blobel and Dobberstein, $1975 \mathrm{a}, \mathrm{b})$ as a mechanism by which proteins are initially translocated into the ER lumen. In vitro studies using cell free translation systems supplemented with dog pancreas microsomes, led to the discovery of three of the components involved in the process. One of these, the signal recognition particle (SRP), is a complex of six polypeptides and a 7S RNA 
that interacts with the signal sequence of a nascent polypeptide as it emerges from the ribosome (Walter and Blobel, 1981). Other 'SRP-like' proteins have been recently identified in wheat germ lysate (Prehn et al., 1987) and yeast (Waters et al., 1986). Upon formation of the SRP protein complex via the $54 \mathrm{kDa}$ polypeptide component of SRP; (Krieg et al., 1986) protein chain elongation is temporarily arrested until the complex interacts with the SRP receptor (or docking protein), an integral part of the ER membrane. This may also involve the ER proteins ribophorins I and II in ribosome binding (Crimaudo et al., 1987). The direct interaction of SRP and docking protein elicits the release of elongation arrest and initiation of protein translocation across the ER and release of SRP from the ribosomal complex (Meyer et al., 1982; Gilmore et al., 1982). During translocation the signal sequence is proteolytically cleaved by a membrane located signal peptidase, which has been isolated as a complex of at least four polypeptides (Evans et al., 1986). The peptidase may constitute part of a larger complex which acts as a pore through the membrane (Evans et al., 1986).

The arrest of nascent chain synthesis by SRP is an intriguing phenomenon, and has been shown to occur only in heterologous systems, such as canine SRP and wheat germ lysate (Gilmore et al., 1982) and yeast lysate (Rothblatt and Meyer, 1986), and not in homologous systems such as canine SRP and reticulocyte lysate (Meyer, 1985). These data suggest that elongation arrest is caused by an incompatability of components in heterologous in vitro systems.

Until recently, translocation across the ER was thought to 
be strictly co-translational (Blobel and Dobberstein, $1975 \mathrm{a}, \mathrm{b}$ ). However, recent findings showed that the synthesis of secretory proteins could be uncoupled from their translocation (Ainger and Meyer, 1986). In this study, SRP was used to arrest chain elongation during a synchronised translation, resulting in nascent chains of increasing length. It was found that SRP could still bring about arrest after $75 \%$ of the chain was complete, of which half were translocated. Translocation may even occur posttranslationally, although inefficiently, as shown for a truncated form of the human glucose transporter (Mueckler and Lodish, 1986) into dog pancreas microsomes and prepro $\propto$ factor into yeast microsomes (Waters and Blobel, 1986; Waters et al., 1986).

Translocation is an energy-dependent process, and is similar in its requirement of ATP, to protein transport across other biological membranes. In yeast, protein translocation across microsomal membranes was reported to be dependent on ATP hydrolysis (Waters and Blobel, 1986), which is thought to be coupled to proton movement across the membranes. However, a requirement for a membrane potential in translocaton could not be demonstrated. In prokaryotes, both types of energy were shown to be necessary. Studies with inverted membrane vesicles from $E$. coli lacking functional F1Fo-ATPase found translocation of the precursor to outer membrane protein A, proOmpA (Geller et al., 1986) and a fusion protein between the outer membrane protein $F$ and lipoprotein, OmpF-11p (Yamane et al., 1987) to be dependent on ATP and membrane electrochemical potential, but by neither alone.

Proteins that enter the secretory pathway are eventually 
secreted or localised in one of several distinct subcellular compartments: the ER, the Golgi complex, the lysosome or plasma membrane. What dictates targeting of these different subsets of proteins is not fully understood, although extensive studies support the view that proteins contain sorting signals specifying movement between organelles, which are recognised by unique molecular machinery within the cell.

Proteins that permanently reside in the ER are distinguished from newly synthesised secretory proteins, which pass through this compartment, by a retention signal in the carboxy terminus of the protein. Munro and Pelham (1987) showed that deletion or extension of a C-terminal sequence lys asp glu leu in the ER luminal protein grp 78 , resulted in its secretion. Conversely, a fusion protein containing the C-terminal six amino acids of grp 78 attached to chicken lysozyme failed to be secreted and was retained in the ER. A similar short consensus sequence glu glu $x x x$ ile/val gln, has been identified by sequence analysis of different ER proteins. These sequences are thought to constitute a putative signal for recognition of ER proteins by specific ER receptors (Albright and Robbins, 1986).

Lysosomal proteins and cell surface proteins are sorted from one another, at or near the Golgi (Farquhar and Palade, 1981). In mammalian cells, protein delivery to the lysosome is receptor-mediated (Sly and Fisher, 1982). The presence of mannose-6-phosphate residues on the proteins is recognised by a specific receptor in the Golgi, which is responsible for delivery to the lysosome. Yeast cells use a simpler sorting mechanism that does not require carbohydrate for targeting to 
the vacuole (a lysosome-like compartment). Gene fusions using the amino terminal 50 amino acids of carboxypeptidase $\mathrm{Y}$, a vacuolar protease, attached to invertase, a secreted protein, allowed delivery of the hybrid protein to the yeast vacuole. This sequence consists of the N-terminal signal sequence followed by a vacuole sorting signal (Johnson et al., 1987). The observation that mutant vacuolar proteins were secreted as a result of missorting, has allowed the identification of at least 14 complementation groups involved in targeting of soluble vacuolar proteins (Bankaitis et al., 1986; Rothman and Stevens, 1986).

It is not known how the sorting of secretory and vacualar proteins occurs, the cell machinery may use acidity differences between intracellular organelles, as observed for movement of secretory proteins between the Golgi and secretory vesicles (Orci et al., 1987). The pH gradient may allow one way traffic of proteins to various compartments by endocytosis and exocytosis (Kelly, 1987). Yeast mutants deficient in intracellular sorting may allow direct testing of such sorting mechanisms (Bankaitis et al., 1986; Rothman and Stevens, 1986; and Riezman, 1985). 


\subsection{ATMS OF PHD STUDY.}

The overall aim of this $\mathrm{PhD}$ study was to investigate the location and nature of targeting signals which direct the beta subunit precursor of yeast ATP synthase to the mitochondrial matrix. Specifically, they were:

to determine the amino acid sequence of the precursor by sequencing the ATP2 gene, with a view to mutating in vitro the cloned gene in order to manipulate the $\mathrm{N}$-terminal presequence. Deletion and gene fusion experiments of the presequence attached to a cytosolic protein can be used to determine the minimal requirement of amino acid sequence to constitute a targeting signal.

to set up a transcription-translation system in vitro to synthesise radiolabelled mutant precursor polypeptides.

to construct a yeast strain lacking F1-ATPase beta subunit. This would be a suitable host to examine transport of plasmid-encoded mutant beta subunit polypeptides in the absence of the normal chromosomal-encoded protein.

(iv) to develop a plate assay for screening mutant targeting sequences expressed in the atp2 yeast strain. The approach would make use of the strain's inability to grow on non-fermentable carbon as sole carbon source, a consequence of the defect in beta subunit expression and oxidative phosphorylation. Expression of plasmid-encoded mutant polypeptides which are able to be correctly transported into the mitochondrion and assembled into the ATP synthase complex, should restore growth on glycerol or ethanol as sole carbon 
sources.

Analysis of the structural gene encoding the beta subunit pecursor will allow a better understanding of the localisation of proteins in yeast mitochondria. This study would contribute to a well established research effort on mitochondrial biogenesis; in particular the import of nuclear-encoded proteins. 



\section{MATERIALS AND METHODS.}

\subsection{STRAINS AND PLASMIDS.}

The strains of Saccharomyces cerevisae used are listed in Table 2.1. The atp2 yeast mutants JQ1 and GR1 were derived from SF747-19D, by one-step gene disruption of the ATP2 locus, encoding beta subunit of yeast ATP synthase. The Escherichia coli strains used are listed in Table 2.2 .

Plasmid pFL1-11-3 (provided by G. A. Reid) contains a 2.65 $\mathrm{kb}$ fragment of yeast DNA containing the entire ATP2 gene, cloned into the unique BamHI site of pFL1. Plasmid pJ-14 (kindly given by M.G. Douglas) contains a $11 \mathrm{~kb}$ fragment of yeast genomic DNA including the entire ATP2 gene in the unique BamHI site of YEp13 (see figures 2.1 and 2.2). Plasmid pMC4 is derived from pAC1, containing the yeast alcohol dehydrogenase 1 promoter (McKnight and McConaughty, 1983) and the COXIV gene (Hurt et al., 1984). The COXIV gene was replaced by a $2.3 \mathrm{~kb}$ EcoRI-SmaI fragment containing the ATP2 gene, to give pMC4-F1 $\beta$ (see figure 2.3). Plasmid pVT102A is a derivative of pVT100-U series (Vernet et al., 1987) which contains a unique EcoRI restriction site for gene cloning between the yeast $A D H 1$ promoter and terminator (provided by G. A. Reid). It was used for subcloning (see figure 2.4). These plasmids were transformed into SF747, JQ1 and GR1. D273-10B (ATCC 24657) was used for preparation of mitochondria.

Plasmids pDS6 and pDS7 (essentially pDS5/2) contain pBR322 DNA, the bacteriophage T5 promoter P25 $(0 / x)$, lambda transcriptional termination signals, and the genes for 
Table 2.1. STRAINS OF SACCHAROMYCES CEREVISAE USED.

\begin{tabular}{|c|c|c|}
\hline STRAIN & GENOTYPE & SOURCE \\
\hline$D 273-10 B$ & $\begin{array}{l}\text { ATCC. } 24657 \\
\text { MATd, wild type }\end{array}$ & G. A. Reid \\
\hline SF $747-190$ & 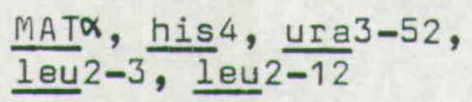 & R. Schekman \\
\hline JQ1 & 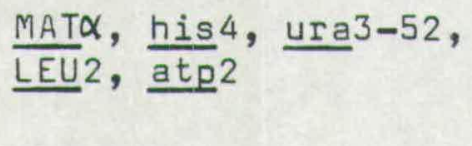 & $\begin{array}{l}\text { J. Quinn, } \\
\text { M. E. Loyda } \\
\text { G. A. Reid }\end{array}$ \\
\hline GR1 & 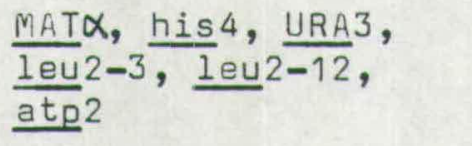 & $\begin{array}{l}\text { P. Smith, } \\
\text { G. A. Reid, } \\
\text { M. E. Lloyd }\end{array}$ \\
\hline
\end{tabular}

a) Department of Microbiology, University of Edinburgh, Edinburgh.

b) Department of Biochemistry, University of California, Berkeley. 
Table 2.2. STRAINS OF ESCHERICHIA COLI USED.

\begin{tabular}{|c|c|c|}
\hline STRAIN & GENOTYPE & SOURCE \\
\hline BD1528 & $\begin{array}{l}\text { thyA, met-, nadBF, ung-1, gal-, supE, supF, } \\
\text { hsdR-, hsdM+ }\end{array}$ & D. Lilleya \\
\hline HB1O1 & $\begin{array}{l}\text { leuB, } F^{-} \text {, hsd R-, hsdM-, recA13, ara-14, } \\
\text { proA2, xyl-5, lacY1, galk2, rps L2O }\left(\mathrm{Sm}^{\mathrm{R}}\right) \text {, } \\
\text { mtl-1, SupE } 44, \lambda-\end{array}$ & G. A. Reidb \\
\hline MM294 & Pro- , endoA- , thi- ${ }^{-}$hsdR- ${ }^{-}$hsdM $^{+}$ & D. Lilleya \\
\hline NM522 & $\begin{array}{l}\text { (lac-pro) } \Delta,(\text { hsdMS }) \Delta, \text { supE, F'lacZ } \Delta M 15 \\
\text { lacIq }\end{array}$ & N. Murrayc \\
\hline
\end{tabular}

a) Department of Biochemistry, University of Dundee, Dundee.

b) Department of Microbiology, University of Edinburgh, Edinburgh .

c) Department of Molecular Biology, University of Edinburgh, Edinburgh. 


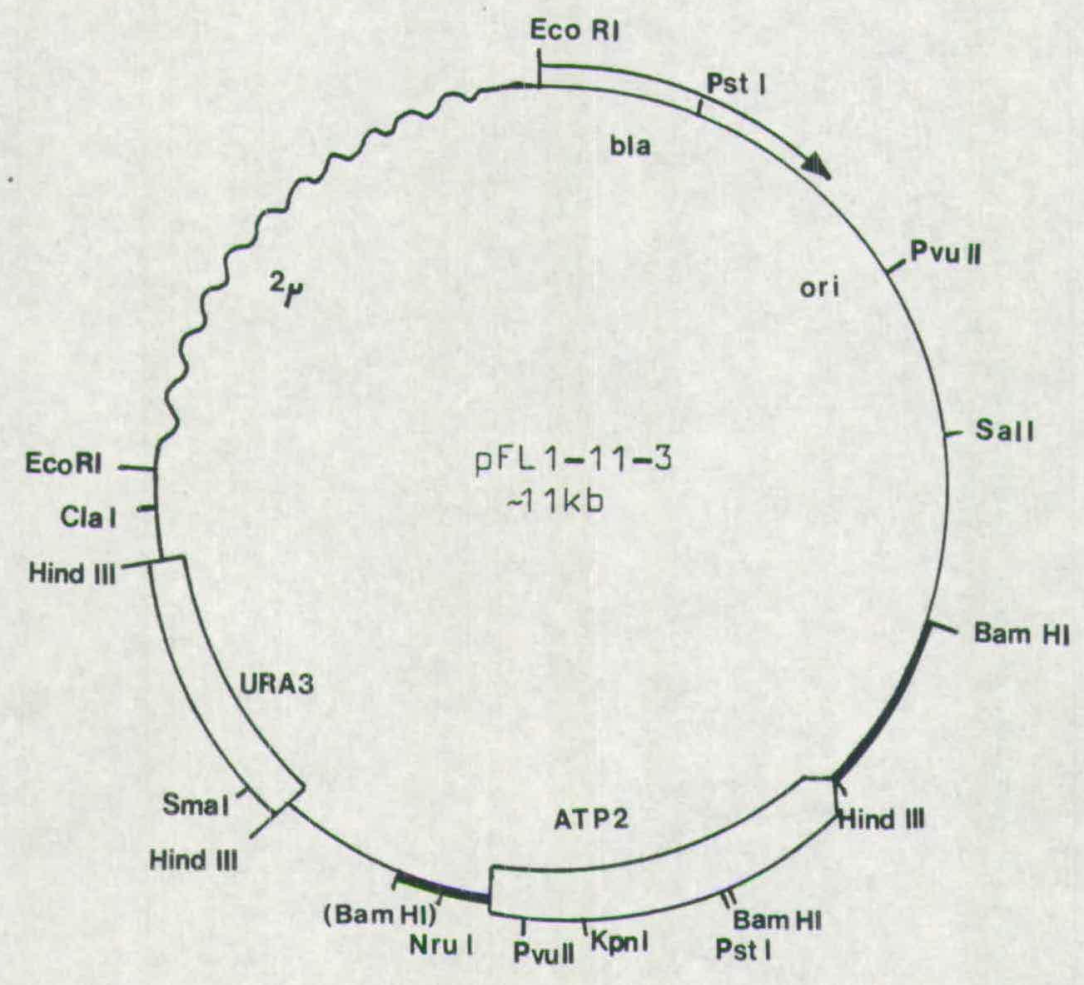

Origin: Isolated from PFL 1 clone bank (Sau3A fragments of yeast DNA in $\mathrm{PF}(1)$ by hybrid-select translation; labelled polypeptide immunoprecipitated with antiserum against yeast F1ATPase beta subunit (G. A. Reid).

Plasmid PFL1: Chevallier et al., (1980) Gene 11, 11-19 


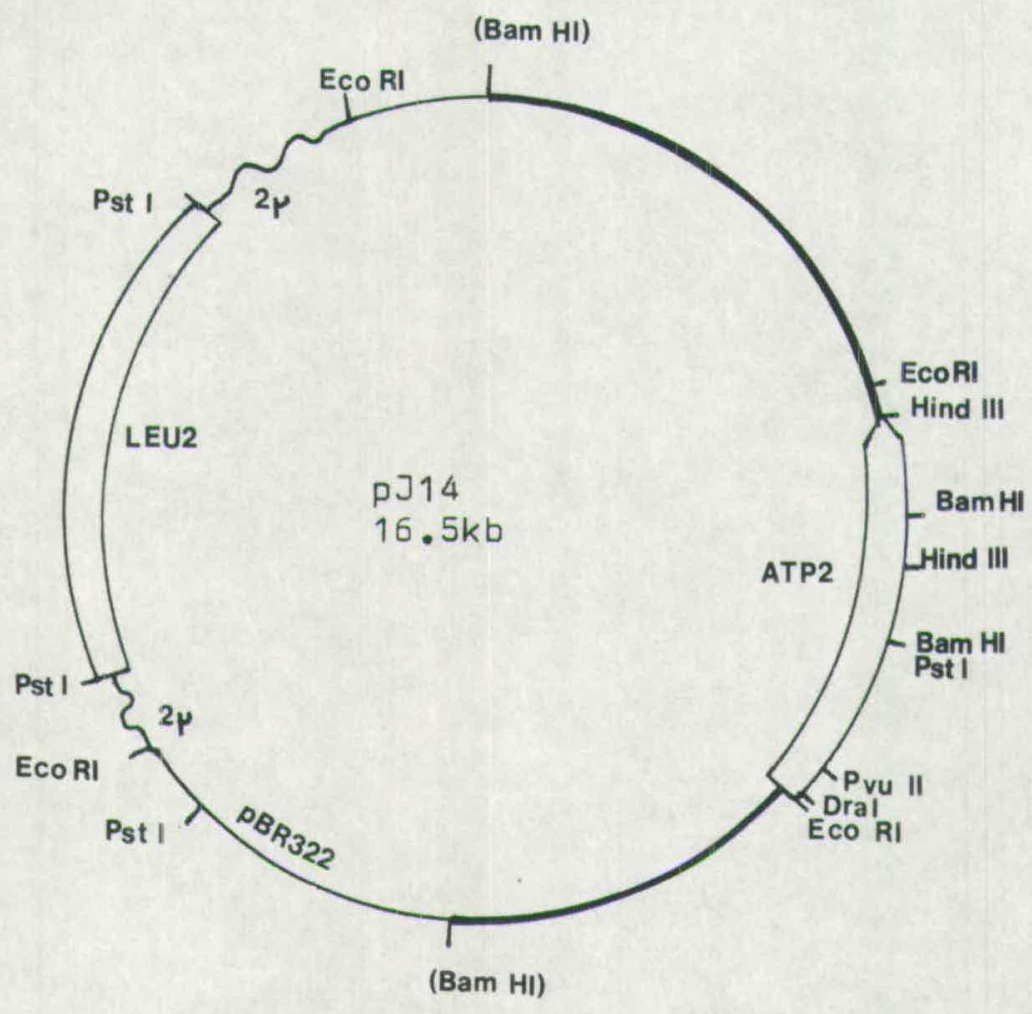

Origin: Isolated from YEp13 clone bank (Sau3A fragments of yeast genomic DNA in YEp13) by complementation of yeast pet mutant lacking in F1ATPase beta subunit.

Plasmid pJ14: Saltzgaber-Muller. et al., (1983) J. Biol. Chem $\underline{258}(19), 11465-11470$ 
FiquIe 2.3. THE E. COLI/YEAST PLASMID PMC4-F13

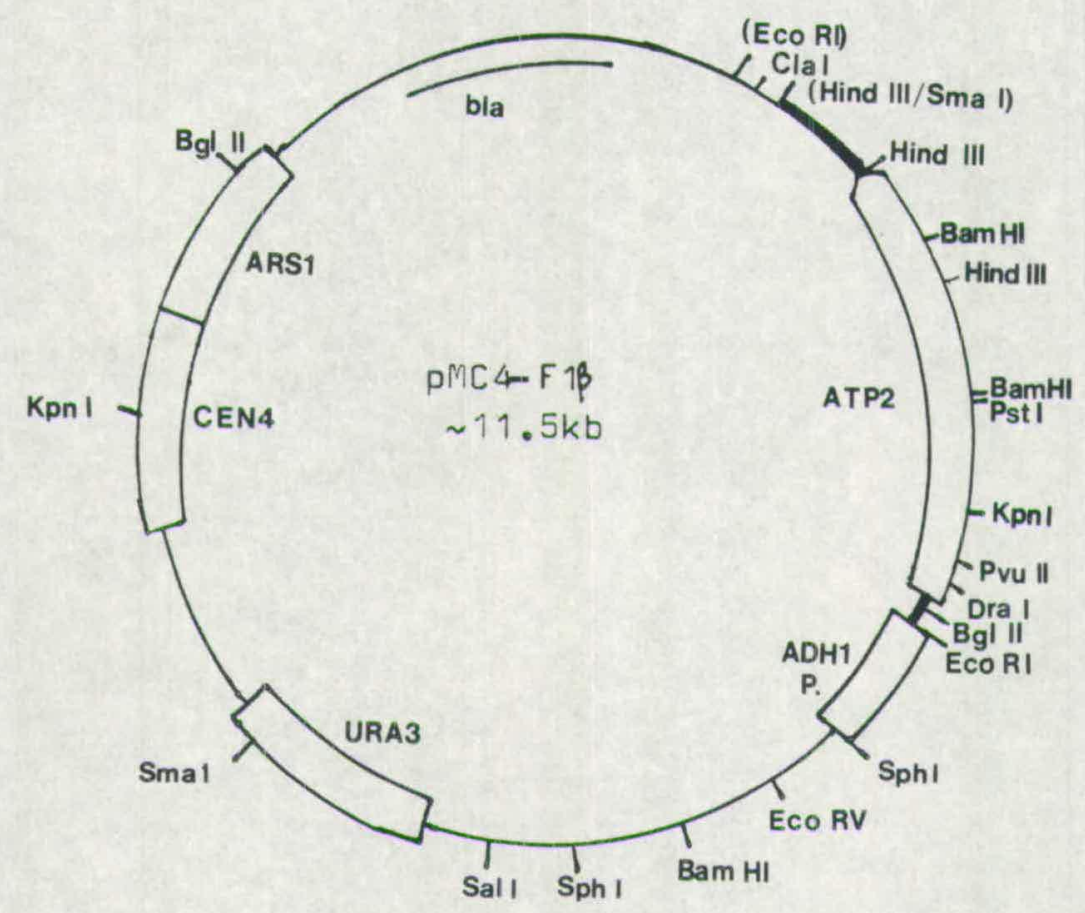

Plasmid PMC4 (kindly given by G. Schatz) contains the COXIV gene behind the ADH1 promoter. The COXIV gene and CYC1 terminator DNA sequences in pMC4 were replaced by the F1-ATPase beta subunit coding region and 3 ' downstream DNA (terminator).

Plasmid pMC4: Hurt et al., (1985b) EMBO J. 4, 3509 


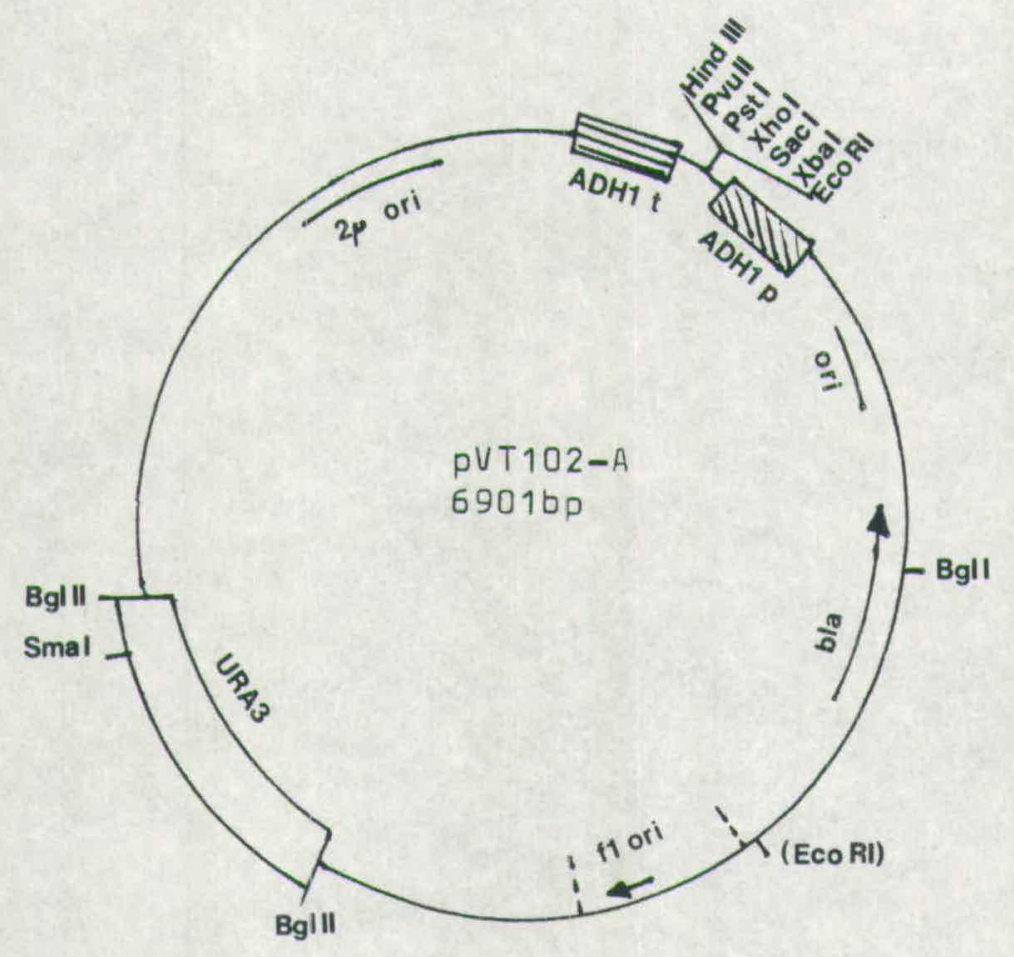

Origin: pVT102-A was derived from the plasmid pVT100U series. The EcoR1 site near the f1 origin was destroyed by Klenow reaction, and the recombinant plasmids pVT-R1 were isolated. The pVTR1 plasmids were cut with BamH1 (in the polylinker), filled in with Klenow, ligated with EcoR1 linkers ( $P$ GGAATTCC), cut with ECOR1 and religated.

Plasmid pVT100U series: Vernet et al., (1987) Gene $\underline{52}$, $225-233$ 
Fiqure 2.5. THE E.COLI PLASMID PDS6

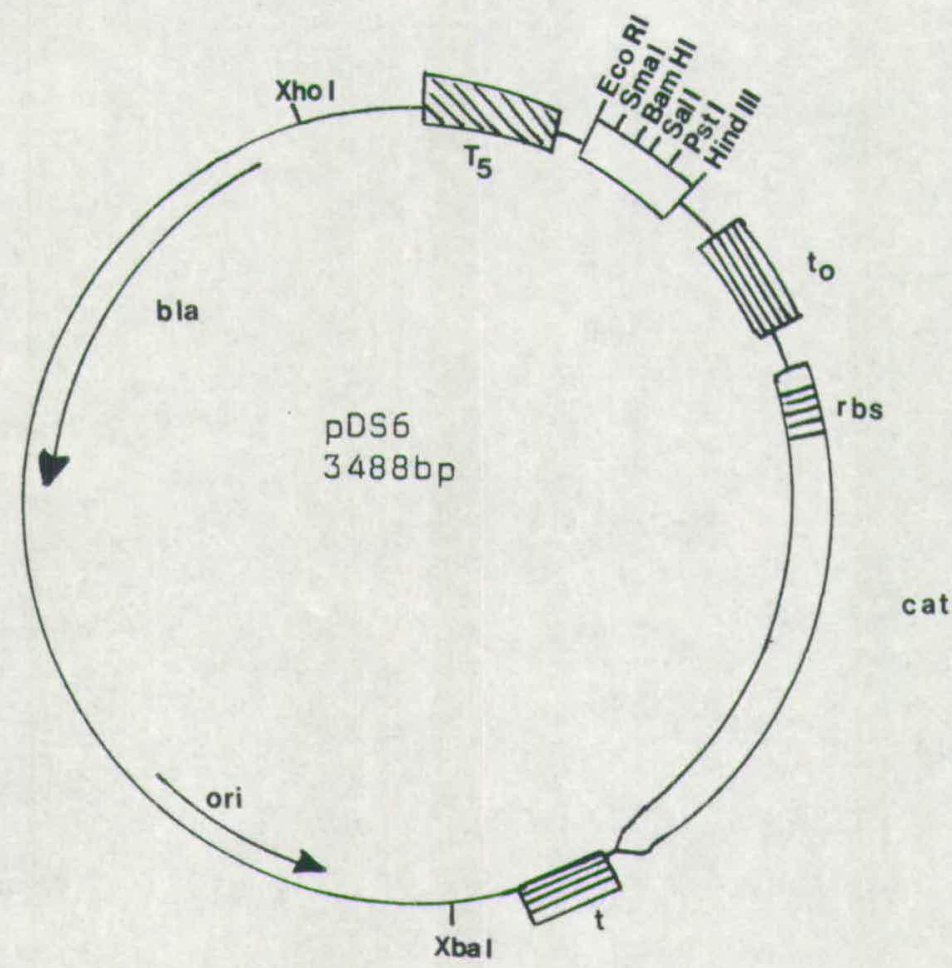

The expression plasmid pDS6 enables DNA sequences of interest to be inserted at any of six unique restriction endonuclease sites between the $T_{5}$ phage promoter, and the $t$ terminator.

Transformants containing the plasmid can be selected for resistance to ampicillin or chloramphenicol.

Plasmid pDS6: Stueber et al., (1984) EMBO J. $\underline{3}(13)$, $3143-3148$ 
Fiqure 2.6. THE E.COLI PLASMID DDS?

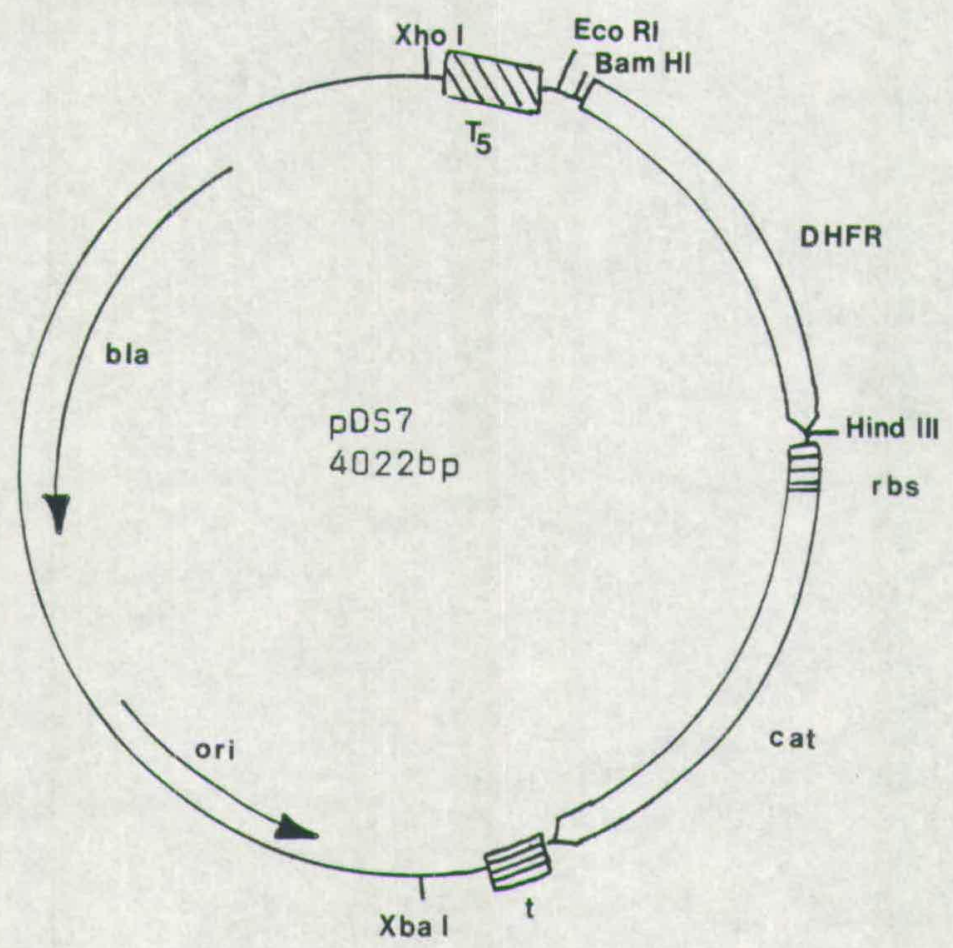

Plasmid pDS7 is a derivative of pDS6 directing expression of the mouse dihydrofolate reductase (DHFR) gene from the phage $T_{5}$ promoter. The unique Eco RI and Bam HI sites between the promoter and the DHFR coding sequence permit insertion of exogenous DNA such that fusion proteins can similarly be expressed.

Plasmid PDS7: Stueber et al., (1984) EMBO J. $\underline{3}(13)$, $3143-3148$. 


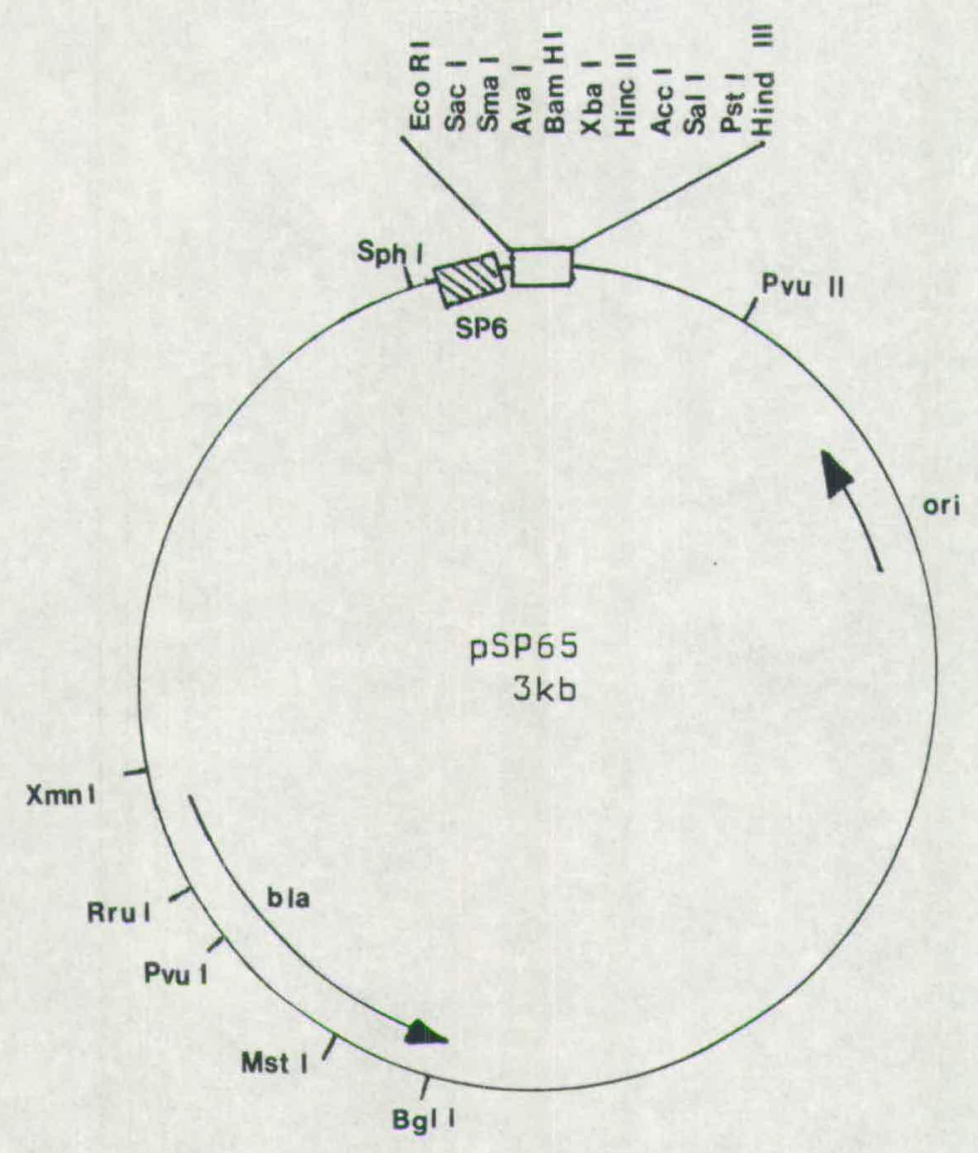

The in vitro expression plasmid pSP65 contains the polylinker from pUC18 for cloning of desired genes behind SP6 bacteriophage promoter. Selection of transformants is by ampicillin resistance.

Plasmid pSP65: Melton et al., (1984) Nuc. Acids Res. 12(18), $7035-70 \overline{56}$ 
chloramphenicol acetyltransferase $(C A T)$ and mouse dihydrofolate reductase $(D H F R)$; see figures 2.5 and 2.6 (Stueber et al., 1984). Plasmid pSP65 contains the SP6 bacteriophage promoter cloned into a pUC12 derivative with a polylinker attached directly to the transcription initation site; see figure 2.7 (Melton et al., 1984). These plasmids were used for subcloning, in vitro transcription and in vitro mutagenesis.

\subsection{CULTURE CONDITIONS AND GROWTH MEDIA.}

Strains of $E$. coli were routinely maintained on L-agar plates (with antibiotic supplementation for maintenance of plasmids), and subcultured every 2-3 weeks. Permanent stocks were made as $20 \%$ glycerol cultures using stationary phase liquid cultures, stored at $-70^{\circ} \mathrm{C}$ (Maniatis et al., 1982). Cultures were grown at $37^{\circ} \mathrm{C} 180 \mathrm{r} . \mathrm{p} . \mathrm{m}$. in an oscillating orbital shaker.

The liquid medium formulations used were according to Maniatis et al., (1982):

(1) LB-Medium. per litre: Bactotryptone $10 \mathrm{~g}$ $\begin{array}{ll}\mathrm{NaCl} & 5 \mathrm{~g} \\ \text { Yeast Extract } & 5 \mathrm{~g}\end{array}$

(2) M9 salts (10x). per litre:

$\begin{array}{lr}\mathrm{Na}_{2} \mathrm{HPO}_{4} & 60 \mathrm{~g} \\ \mathrm{KH}_{2} \mathrm{PO}_{4} & 30 \mathrm{~g} \\ \mathrm{NaCl} & 5 \mathrm{~g} \\ \mathrm{NH}_{4} \mathrm{Cl} & 10 \mathrm{~g}\end{array}$


(3) M9 Medium. per litre:

$$
\begin{array}{ll}
10 \mathrm{x} \text { M9 salts } & 100 \mathrm{ml} \\
\mathrm{H}_{2} \mathrm{O} & 883 \mathrm{ml}
\end{array}
$$

The M9 salts solution was autoclaved and allowed to cool before the following were added:

$\begin{array}{lr}1 \mathrm{MgSO}_{4} & 2 \mathrm{ml} \\ 1 \mathrm{M} \text { glucose } & 10 \mathrm{ml} \\ 1 \% \text { thiamine } & 1 \mathrm{ml}\end{array}$

The above solutions were sterilised separately by filtration (thiamine) or autoclaving.

Media containing agar for plates was made according to the appropriate formula for liquid media. Just before autoclaving, $20 \mathrm{~g}$ Oxoid No 3 agar per litre was added. After cooling to $55^{\circ} \mathrm{C}$ the vitamin or antibiotic supplements were added, and the plates poured.

(4) 2x YT Top Agar. per litre:

$\begin{array}{ll}\text { Bactotryptone } & 8 \mathrm{~g} \\ \text { Yeast Extract } & 5 \mathrm{~g} \\ \mathrm{NaCl} & 5 \mathrm{~g} \\ \text { Oxoid No } 3 \text { agar } & 7 \mathrm{~g}\end{array}$

(5) Antibiotics.

For selection and maintenance of ampicillin resistant transformants, media were supplemented with $50 \mu \mathrm{g} / \mathrm{ml}$ ampicillin, 
or $30 \mu \mathrm{g} / \mathrm{ml}$ chloramphenicol for chloramphenicol resistance (Maniatis et al., 1982).

Yeast strains were maintained on YPD plates at $4^{\circ} \mathrm{C}$, and subcultured monthly. Minimal medium agar with appropriate supplements was used for selection of plasmid in transformants with specific auxotrophic requirements. Permanent stocks were made from stationary phase liquid cultures as $20 \%$ glycerol cultures and stored frozen at $-70^{\circ} \mathrm{C}$. Cultures were grown at $30^{\circ} \mathrm{C}$ and 180 r.p.m. on an orbital shaker.

The following medium formulations were used:

(1) SD Minimal Medium.

per litre:

$\begin{array}{lr}\text { Yeast Nitrogen Base } & 1.7 \mathrm{~g} \\ \text { (without amino acids) } & \\ \left(\mathrm{NH}_{4}\right)_{2} \mathrm{SO}_{4} & 5 \mathrm{~g} \\ \text { Glucose } & 20 \mathrm{~g}\end{array}$

Amino acid supplements were added at $100 \mathrm{mg} / \mathrm{l}$ before autoclaving.

Glucose was replaced by glycerol (2\%) in SG Minimal Medium and sodium lactate $\mathrm{pH} 6.0(2 \%)$ in SL Minimal Medium.

(2) YPD.

$\begin{array}{lll}\text { per litre: } & \text { Yeast Extract } & 10 \mathrm{~g} \\ & \text { Bactopeptone } & 20 \mathrm{~g} \\ & \text { Glucose } & 20 \mathrm{~g}\end{array}$


YPL and YPEG medium was essentially the same except that the glucose was replaced with either $2 \%$ sodium lactate $\mathrm{pH} 6.0$ (YPL) or $2 \%$ glycerol, 3\% ethanol (YPEG). Medium termed "0.1\% YPD", contained $0.1 \%$ glucose instead of $2 \%$ glucose. YPDG medium contained $0.1 \%$ glucose and $3 \%$ glycerol.

Media containing agar for plates contained $20 \mathrm{~g}$ Oxoid No 3 agar per litre, added before autoclaving.

\section{(3) 2\% Lactate Medium.}

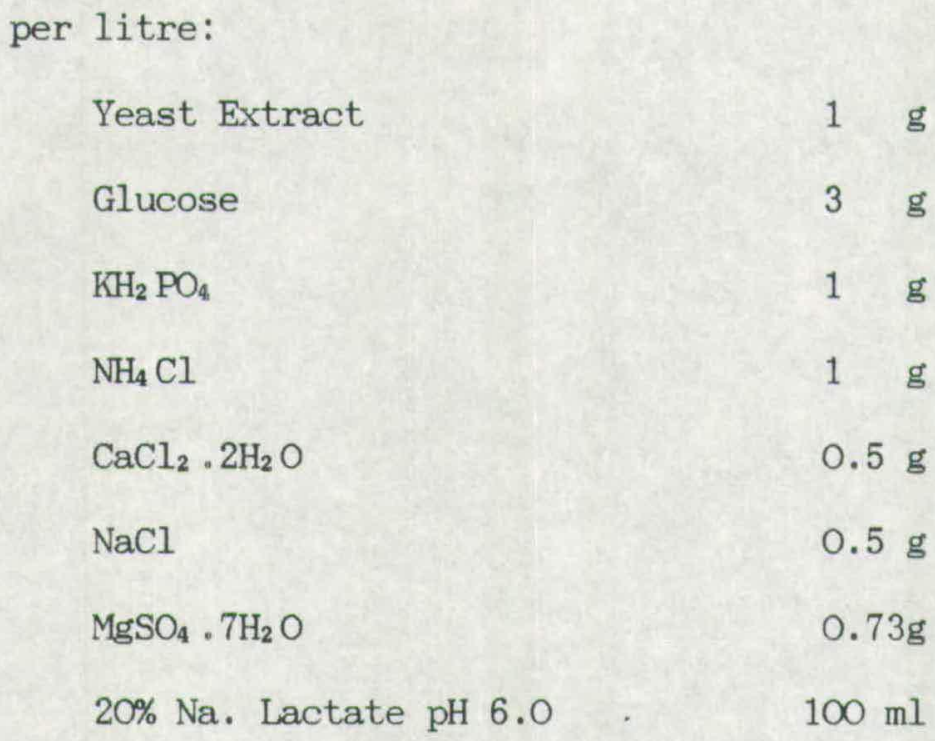

(4) Sulphate Free Lactate Medium.

per litre:

Yeast Extract

$3 \mathrm{~g}$

$\mathrm{KH}_{2} \mathrm{PO}_{4}$

$1 \mathrm{~g}$

Glucose

$1 \mathrm{~g}$

$\mathrm{NH}_{4} \mathrm{Cl}$

$1 g$

$\mathrm{CaCl}_{2} \cdot 2 \mathrm{H}_{2} \mathrm{O}$

$0.5 \mathrm{~g}$

$\mathrm{NaCl}$

$0.5 \mathrm{~g}$

$\mathrm{MgSO}_{4} \cdot 7 \mathrm{H}_{2} \mathrm{O}$

$0.73 \mathrm{~g}$

$20 \%$ Na.Lactate pH6.O

$100 \mathrm{ml}$ 
(5) Sulphate Free Minimal Medium (modified from Van Loon et al., (1986))

per litre:

$\mathrm{NH}_{4} \mathrm{Cl}$

$1 \mathrm{~g}$

Yeast Nitrogen Base

$1.7 \mathrm{~g}$

(without amino acids)

Glucose

$20 \mathrm{~g}$

L-Histidine

$50 \quad \mathrm{mg}$

L-Asparagine

$0.5 \mathrm{~g}$

(6) Regeneration Agar.

per litre:

$\begin{array}{lcc}\text { Sorbitol } & 182 & \mathrm{~g} \\ \text { Agar } & 20 & \mathbf{g} \\ \text { Yeast Nitrogen Base } & 1.7 & \mathrm{~g} \\ \begin{array}{l}\left.\mathrm{NH}_{4}\right)_{2} \mathrm{SO}_{4} \\ \text { Glucose }\end{array} & 5 & \mathrm{~g} \\ & 20 & \mathrm{~g}\end{array}$

Aliquots $(20 \mathrm{ml})$ were dispensed in Erlenmeyer bottles before autoclaving. The agar was boiled, allowed to cool to $55^{\circ} \mathrm{C}$ and amino acid supplements added (50 $\mathrm{mg} / 1$ ) before use. 


\subsection{BUFFERS AND SOLUTIONS}

The following buffers and solutions were used for DNA and RNA manipulations (Maniatis et al., 1982 ):

(1) TE Buffer: $10 \mathrm{mM}$ Tris $\mathrm{HCl} ; 1 \mathrm{mM}$ EDTA.

(2) TEG: $25 \mathrm{mM}$ Tris HCl; $10 \mathrm{mM}$ EDTA; $50 \mathrm{mM}$ Glucose, $\mathrm{pH} 8.0$.

(3) 10x TNE: $500 \mathrm{mM}$ Tris $\mathrm{HCl}$; $50 \mathrm{mM}$ EDTA; $1 \mathrm{M} \mathrm{NaCl}, \mathrm{pH} 7.5$.

(4) 2Ox SSC: $3 \mathrm{M} \mathrm{NaCl} ; 0.3 \mathrm{M} \mathrm{Na}$. citrate, $\mathrm{pH} 7.0$.

(5) Buffers for Restriction Enzyme Digests:

10x stocks made from sterile components, filter sterilised and aliquots stored at $-20^{\circ} \mathrm{C}$.

10x Low Salt Buffer (LSB): $100 \mathrm{mM}$ Tris $\mathrm{HCl} \mathrm{pH} 7.5 ; 100 \mathrm{mM} \mathrm{MgCl}_{2}$; $10 \mathrm{mM}$ DTT.

10x Medium Salt Buffer(MSB): $100 \mathrm{mM}$ Tris $\mathrm{HCl} \mathrm{pH} 7.5 ; 500 \mathrm{mM} \mathrm{NaCl}$; $100 \mathrm{mM} \mathrm{MgCl}{ }_{2} ; 10 \mathrm{mM}$ DTT.

10x High Salt Buffer(HSB): $500 \mathrm{mM}$ Tris $\mathrm{HCl}, \mathrm{pH} 7.5 ; 1 \mathrm{M} \mathrm{NaCl}$; $100 \mathrm{mM} \mathrm{MgCl}_{2} ; 10 \mathrm{mM}$ DTT.

10x Smal buffer: $200 \mathrm{mM} \mathrm{KCl} ; 100 \mathrm{mM}$ Tris $\mathrm{HCl}, \mathrm{pH} 8.0 ; 100 \mathrm{mM}$ $\mathrm{MgCl}_{2} ; 10 \mathrm{mM}$ DTT. 
(6) RNase A: $2 \mathrm{mg} / \mathrm{ml}$ stock.

$2 \mathrm{mg}$ pancreatic RNase $\mathrm{A}$ in $1 \mathrm{ml} 1 \mathrm{x} \mathrm{TNE}$, which was heated at $85-100^{\circ} \mathrm{C}$ for $10 \mathrm{~min}$ to inactivate DNase contaminants. After cooling, $1 \mathrm{ml}$ aliquots were stored $-20^{\circ} \mathrm{C}$.

(7) Buffers for DNA sequencing (Sanger, et al., 1977):

(1) $0.1 \mathrm{M}$ Tris $\mathrm{HCl} \mathrm{pH} 8.0 ; 50 \mathrm{mM} \mathrm{MgCl}_{2}$.

(2) $10 \mathrm{mM}$ Tris $\mathrm{HCl} \mathrm{pH} 8.0$.

(3) Termination mixes.

\begin{tabular}{|c|c|c|c|c|}
\hline & $\mathrm{T}$ & C & G & A \\
\hline $0.5 \mathrm{mM}$ dTTP & 2.5 & 50 & 50 & 35 \\
\hline $0.5 \mathrm{mM}$ dCTP & 50 & 2.5 & 50 & 35 \\
\hline $0.5 \mathrm{mM}$ dGTP & 50 & 50 & 2.5 & 35 \\
\hline $3.3 \mathrm{mM}$ ddTTP & 102.5 & & & \\
\hline $0.1 \mathrm{mM}$ ddCTP & & 102.5 & & \\
\hline $0.2 \mathrm{mM}$ ddGTP & & & 102.5 & \\
\hline $0.13 \mathrm{mM}$ ddATP & & & & 17.5 \\
\hline $10 \mathrm{mM}$ Tris $\mathrm{pH} 8$ & & & & 87.5 \\
\hline$\mu l$ & 205 & 205 & 205 & 210 \\
\hline
\end{tabular}

(4) Chase mix: $0.5 \mathrm{mM}$ each of dNTP, (dCTP, dGTP, dTTP, dATP).

(5) Formamide/dye mix: $100 \mathrm{ml}$ formamide was deionised by stirring gently with $5 \mathrm{~g}$ Amberlite MB1 for $30 \mathrm{~min}$, and filtered. To this 
added $30 \mathrm{mg}$ xylene cyanol $\mathrm{FF}, 30 \mathrm{mg}$ bromophenol blue and $\mathrm{Na}_{2}$. EDTA to $20 \mathrm{mM}$. The dye mix was stored at room temperature.

(6) Sequencing gel stocks: Stocks were stored at $4^{\circ} \mathrm{C}$, and warmed to room temperature before preparing the gradient gel.

$\begin{array}{lll}30 \% \text { acrylamide:bisacrylamide } & \text { Top } & \text { Bottom } \\ (29: 1) & 6 \mathrm{ml} & 1.25 \mathrm{ml} \\ \text { urea } & 13.8 \mathrm{~g} & 2.87 \mathrm{~g} \\ \text { sucrose } & 0 \mathrm{~g} & 0.625 \mathrm{~g} \\ 10 \mathrm{x} \text { TBE } & 1.5 \mathrm{ml} & 1.56 \mathrm{ml} \\ 1 \% \text { bromophenol blue } & 0 \mathrm{ml} & 0.2 \mathrm{ml} \\ \text { water } & 30 \mathrm{ml} & 6.25 \mathrm{ml}\end{array}$

(7) Buffers for gel electrophoresis of RNA and DNA:

Gel loading buffer for RNA and DNA: $50 \mathrm{mM}$ glycerol; $1 \mathrm{mM}$ EDTA pH 8.0; $0.4 \%$ bromophenol blue. The buffer was made from sterile stocks, and kept at room temperature.

5x RNA electrophoresis buffer (Maniatis et al., 1982.): 0.2M MOPS $\mathrm{pH} 7.0 ; 50 \mathrm{mM}$ Sodium acetate; $5 \mathrm{mM}$ EDTA.

10x TBE: $0.89 \mathrm{M}$ Tris; 0.89M Boric Acid; $20 \mathrm{mM}$ EDTA pH 8.0.

NOTE: Buffers and distilled water which were used for RNA work were treated with $0.3 \%$ diethylpyrocarbonate (DEPC) for 24 hours at room temperature, before autoclaving. 
(8) Buffers used in yeast transformation (spheroplast method).

STC buffer:(1M sorbitol; $10 \mathrm{mM} \mathrm{CaCl}_{2} ; 10 \mathrm{mM}$ Tris $\mathrm{HCl} \mathrm{pH} 7.5$ ). The solution was autoclaved in $50 \mathrm{ml}$ aliquots.

$20 \%$ (w/v) PEG: $\left(20 \%\right.$ w/v PEG $4000 ; 10 \mathrm{mM} \mathrm{CaCl}_{2} ; 10 \mathrm{mM}$ Tris $\mathrm{HCl}$ $\mathrm{pH} 7.4)$. PEG was filter sterilised and frozen at $-20^{\circ} \mathrm{C}$ in $5 \mathrm{ml}$ aliquots.

\section{SOS medium:}

This was made up by mixing $10 \mathrm{ml}$ of $1 \mathrm{M}$ sorbitol; $6.7 \mathrm{ml}$ YPD; $1.3 \mathrm{ml} 100 \mathrm{mM} \mathrm{CaCl} 2 ; 27 \mathrm{ul}$ of $5 \mathrm{mg} / \mathrm{ml}$ of the marker amino acid and $2 \mathrm{ml}$ water. The mixture was filter sterilised and stored as $2 \mathrm{ml}$ aliquots.

\subsection{ISOLATION OF DNA FROM E.COLI.}

Small scale and large scale isolation of plasmid DNA from transformed $E$. coli, was essentially according to Birnboim and Doly (1979). Plasmid DNA for cloning and in-vitro transcription were prepared by the alkaline lysis method (Birnboim and Doly, 1979) and was isolated by $\mathrm{CsCl} /$ ethidium bromide buoyant density gradient (Maniatis et al., 1982).

\subsubsection{Small scale preparation of plasmid DNA.}

$5 \mathrm{ml}$ cultures in LB-medium and $50 \mu \mathrm{g} / \mathrm{ml}$ Ampicillin, were grown to stationary phase at $37^{\circ} \mathrm{C}$ overnight. Cells were harvested for

at 10,000 r.p.m. $h^{5}$ min using the Sorvall $\mathrm{SS} 34$ rotor in $50 \mathrm{ml}$ tubes, and resuspended in 100 $\mu$ l TEG. The suspensions were transferred to sterile $1.5 \mathrm{ml}$ Eppendorf tubes and left for $5 \mathrm{~min}$ at room temperature. Cells were lysed by the addition of $200 \mu \mathrm{l}$ 
$0.2 \mathrm{M} \mathrm{NaOH} / 1 \% \mathrm{SDS}$, vortexed and left for $5 \mathrm{~min}$ on ice. $150 \mu \mathrm{l} 3 \mathrm{M}$ Na. acetate $\mathrm{pH} 5.0$ was added to precipitate chromosomal DNA, mixed by inversion, and left on ice for $5 \mathrm{~min}$, then centrifuged $10 \mathrm{~min}\left(4^{\circ} \mathrm{C}\right)$ in the microfuge. The supernatant was removed and the plasmid DNA was extracted with $0.5 \mathrm{ml}$ phenol:chloroform:8-hydroxyquinoline, (50:50:0.1), followed by $0.5 \mathrm{ml}$ chloroform and ethanol precipitated at room temperature for $5 \mathrm{~min}$ with $0.9 \mathrm{ml}$ absolute ethanol. The ethanol was removed after a $10 \mathrm{~min}$ centrifugation and the DNA pellet dried and resuspended in $50 \mu \mathrm{lE}$.

\subsubsection{Large Scale preparation of plasmid DNA.}

Large scale isolation of plasmid DNA from one litre cultures was carried out as follows:

A $5 \mathrm{ml}$ culture of $\mathrm{E}$. coli in LB-medium $+50 \mu \mathrm{g} / \mathrm{ml}$ ampicillin, was grown overnight at $37^{\circ} \mathrm{C}$. One $\mathrm{ml}$ was used to inoculate a litre of LB-medium + ampicillin. The culture was grown to $\mathrm{OD}_{6} 00$ $=0.6-0.7,1.7 \mathrm{ml} 100 \mathrm{mg} / \mathrm{ml}$ chloramphenicol was added to amplify the plasmid and cells were further grown overnight. The cells were harvested at $10,000 \mathrm{r.p.m} .5 \mathrm{~min}$ at room temperature and resuspended to $9 \mathrm{ml}$ in TEG. The cell suspension was transferred to two $50 \mathrm{ml}$ Sorvall tubes, and $0.5 \mathrm{ml} 15 \mathrm{mg} / \mathrm{ml}$ lysozyme in TEG, added to each tube, quickly vortexed and left $15 \mathrm{~min}$ on ice. Alkaline lysis was carried out by adding $15 \mathrm{ml} \quad 0.2 \mathrm{M} \quad \mathrm{NaOH} ; 1 \%$ SDS, inverting the tubes 2-3 times and keeping on ice 5 min. After this period, $11.25 \mathrm{ml} 3 \mathrm{M}$ sodium acetate $\mathrm{pH} 5.0$ was added, the tubes were inverted 2-3 times and left on ice $60 \mathrm{~min}$, before centrifuging $20,000 \mathrm{r} . \mathrm{p} . \mathrm{m}$. for $45 \mathrm{~min}\left(4^{\circ} \mathrm{C}\right)$ in the Sorvall SS34 
rotor. The supernatant was transferred to a $300 \mathrm{ml}$ Sorvall tube and the DNA precipitated with $45 \mathrm{ml}$ isopropanol for $5 \mathrm{~min}$ at room temperature, and spun 10,000 r.p.m. $20 \mathrm{~min}$.

The pellet was air dried and dissolved in $5.4 \mathrm{ml}$ TE total volume, and transferred to a sterile Corex tube. $\mathrm{CsCl}$ was added $(5.8 \mathrm{~g})$ and left overnight $\left(4^{\circ} \mathrm{C}\right)$, and the precipitate afterwards spun down at 9,000 r.p.m. $30 \min \left(20^{\circ} \mathrm{C}\right)$ to remove RNA. The supernatant was transferred to a clean tube, $0.6 \mathrm{ml}$ ethidium bromide (10 $\mathrm{mg} / \mathrm{ml}$ stock) was added, and centrifuged again. The $\mathrm{CsCl} /$ ethidium buoyant density gradient was formed by centrifuging at 35,000 r.p.m. $\left(20^{\circ} \mathrm{C}\right)$ for $24-48$ hours in the Sorvall oTD65 ultracentrifuge.

Plasmid DNA was removed from the gradient by using a $2 \mathrm{ml}$ syringe to puncture the tube wall, and transferred to silanized $30 \mathrm{ml}$ Corex tubes. The ethidium bromide was extracted by shaking 3-4 times with isopropanol saturated with $\mathrm{NaCl}$ and water until the top layer was clear. The DNA was diluted with $8 \mathrm{ml} \mathrm{TE}$ and precipitated with $8 \mathrm{ml}$ isopropanol for $60 \mathrm{~min}$ at $-20^{\circ} \mathrm{C}$. The DNA was spun down for 20 min at 8.000 r.p.m. $\left(4^{\circ} \mathrm{C}\right)$, dried and dissolved in $400 \mu \mathrm{l}$ TE. Phenol extraction was carried out using $20 \mu \mathrm{l} 4 \mathrm{M} \mathrm{NaCl}, 0.5 \mathrm{ml}$ phenol:chloroform and the DNA was precipitated with $0.8 \mathrm{ml}$ ethanol. After centrifugation the DNA pellet was air-dried and dissolved in $200 \mu \mathrm{l}$ TE.

The DNA concentration was determined from the absorbance at $\mathrm{A}_{260}$, using a $2 \mu \mathrm{l}$ sample in $1 \mathrm{ml} 0.2 \mathrm{M} \mathrm{NaOH}$. This was converted to DNA concentration using the constant $1 \mathrm{~A}_{260}$ unit $=0.05$ $\mathrm{mg} / \mathrm{ml}$.

\subsubsection{ISOLATION OF YEAST CHROMOSOMAL DNA.}


A $10 \mathrm{ml}$ culture of yeast in YPD was grown to stationary phase at $30^{\circ} \mathrm{C}$, the cells were harvested and washed once in distilled water. After the second spin, the cells were resuspended in $0.5 \mathrm{ml} 0.9 \mathrm{M}$ Sorbitol; $0.05 \mathrm{M}$ sodium phosphate buffer $\mathrm{pH} 7.4 ; 14 \mathrm{mM}$ 2-mercaptoethanol containing 2-5 mg/ml Zymolase 5000 and transferred to an Eppendorf tube. The contents of the tube were vortexed for 5 seconds and incubated at $37^{\circ} \mathrm{C}$ for $30 \mathrm{~min}$, and then $50 \mu \mathrm{l}$ of $10 \%$ EDTA was added, vortexed and $50 \mu \mathrm{l} 10 \%$ SDS added. The solution had $100 \mu \mathrm{l} 5 \mathrm{mg} / \mathrm{ml}$ proteinase $\mathrm{K}$ added, mixed and incubated at $65^{\circ} \mathrm{C}$ for $30 \mathrm{~min}$. The tube was allowed to cool before extraction with $500 \mu l$ phenol:chloroform. The upper aqueous phase was removed to another tube and ethanol was added to precipitate the DNA. This was sedimented by centrifuging briefly and the ethanol was decanted. The dried pellet was dissolved in $500 \mu \mathrm{TE}$ and incubated at $65^{\circ} \mathrm{C}$ for $30 \mathrm{~min}$ in the presence of $50 \mu \mathrm{g}$ RNase A. After cooling the DNA was extracted with $500 \mu \mathrm{l}$ phenol:chloroform and precipitated with 0.5 volumes cold ethanol, pelleted, washed in ethanol, dried and resuspended in $50 \mu \mathrm{TE}$.

\subsection{SOUTHERN ANALYSIS OF DNA.}

The protocol for Southern analysis of genomic DNA isolated from yeast, was essentially that of Maniatis et al., (1982).

Yeast chromosomal DNA was digested with the appropriate restriction endonuclease and the DNA fragments separated on a $0.8 \%$ agarose gel in TBE by electrophoresis (Maniatis et al., 1982). After photographing the gel, the DNA was denatured in $0.5 \mathrm{M} \mathrm{NaOH} ; 1.5 \mathrm{M} \mathrm{NaCl}$ for $40 \mathrm{~min}$ (with a change of solution) with gentle shaking, followed by $0.5 \mathrm{M}$ Tris $\mathrm{HCl} \mathrm{pH} 7.4 ; 3 \mathrm{M} \mathrm{NaCl}$ for 
the same time.

The gel was placed upside down on a sheet of 3MM Whatman filter paper soaked in $20 \mathrm{x}$ SSC, the ends resting in a $20 \mathrm{x}$ SSC reservoir. A piece of nitrocellulose filter was wetted in $2 x$ SSC and placed on top of the gel, on top of which three sheets of wet 3 MM paper and 3 inches of paper towels with a weight on top were placed. The DNA was transferred overnight, (12-16 hours) after which the gel position was marked on the nitrocellulose filter. The nitrocellulose filter was immersed in $6 \mathrm{x}$ SSC for 5 min, dried and baked at $80^{\circ} \mathrm{C} 2$ hours under vacuum.

Prehybridisation: the filter was wetted in $6 \mathrm{x}$ SSC and then transferred to a sealable polythene bag, to which $10 \mathrm{ml}$ prehybridisation mixture was added (6x SSC; $5 \mathrm{x}$ Denhardts; $0.5 \%$ SDS containing $0.5 \mathrm{mg}$ heat denatured salmon sperm DNA) and heat sealed. Prehybridisation was over 2 hours at $65^{\circ} \mathrm{C}$.

The DNA probe was synthesised by second strand synthesis using an M13 recombinant containing the entire ATP2 gene. A typical reaction $(30 \mu \mathrm{l})$ contained $10.5 \mu \mathrm{l}$ annealed single-stranded DNA template and 15 mer primer; $10.5 \mu \mathrm{l} 10 \mathrm{mM}$ Tris $\mathrm{HCl} \mathrm{pH} 8.0 ; 0.5 \mu \mathrm{l}$ each of $0.5 \mathrm{mM}$ dGTP, dCTP, dTTP; $2.5 \mathrm{U}$ Klenow fragment; $20 \mu \mathrm{Ci}$ [ $\left.{ }^{32} \mathrm{P}\right] \times \mathrm{dATP}(400 \mu \mathrm{Ci} / \mathrm{mmol})$, and was incubated at $25^{\circ} \mathrm{C}$ for $60 \mathrm{~min}$. After heat denaturation, the probe was added to the prehybridisation solution in the bag, resealed and allowed to hybridise overnight at $65^{\circ} \mathrm{C}$. The filter was removed and washed briefly in $2 \mathrm{x}$ SSC $+0.5 \%$ SDS at room temperature, followed by $2 \mathrm{x}$ $\mathrm{SSC}+0.5 \%$ SDS at room temperature, and $0.1 \mathrm{x}$ SSC $+0.1 \%$ SDS at $68^{\circ} \mathrm{C}$ for 2 hours. The filter was dried and exposed to Agfa X-ray film using an intensifying screen at $-70^{\circ} \mathrm{C}$. 


\subsection{YEAST TRANSFORMATION USING LITHIUM ACETATE.}

Yeast strains were transformed according to Ito et al., (1983) with minor modifications.

A $60 \mathrm{ml}$ YPD culture was inoculated (1:100) with a stationary phase yeast culture and grown at $30^{\circ} \mathrm{C}$ to $\mathrm{OD}_{600}=0.4 .50 \mathrm{mls}$ of culture was harvested in sterile Corex tubes 5,000 r.p.m. for 5 min and washed in TE, spun again and resuspended in $5 \mathrm{ml} T E$. The cells were made competent by the addition of lithium acetate (to a final concentration of $0.1 \mathrm{M}$ ) and incubating for $60 \mathrm{~min}$ at $30^{\circ} \mathrm{C}$.

For transformation, $200 \mu \mathrm{l}$ competent cells were added to $100 \mu \mathrm{lE}$ containing 5-10 $\mu \mathrm{g}$ DNA and incubated at $30^{\circ} \mathrm{C}, 30 \mathrm{~min}$. To each reaction, $700 \mu \mathrm{l} 50 \%$ PEG-4000 was added to give a final concentration of $35 \%$, and heat-shocked at $42^{\circ} \mathrm{C}$ for $5 \mathrm{~min}$. The cells were washed in sterile water, pelleted by centrifugation and finally resuspended in $1 \mathrm{ml}$ YPD and grown up for 1-2 hours at $30^{\circ} \mathrm{C}$. After extensive washing in sterile water, the cells were resuspended in sterile water and plated on the appropriate SD minimal medium plates. Yeast transformants took up to 4-10 days to grow up at $30^{\circ} \mathrm{C}$, and were picked onto fresh plates.

\subsection{YEAST TRANSFORMATION (SPHEROPLAST METHOD).}

A $5 \mathrm{ml}$ yeast culture in YPD, was grown to stationary phase and used to inoculate $100 \mathrm{ml}$ YPD medium $(1: 100)$. The cells were grown to $\mathrm{OD}_{600}=0.4$ and harvested by centrifugation $(5,000$ r.p.m. $5 \mathrm{~min})$. The pellet was resupended in $10 \mathrm{ml} 1 \mathrm{M}$ Sorbitol $\mathrm{pH}$ 7.5, and transferred to $15 \mathrm{ml}$ screw capped tubes. After centrifugation the pellet was resuspended in $5 \mathrm{ml} 1 \mathrm{M}$ Sorbitol, pH 7.5 and incubated with $80 \mu \mathrm{l}$ beta-glucuronidase (Sigma) at 
$30^{\circ} \mathrm{C}$ with periodic shaking. Spheroplast formation was followed by diluting cells in water and looking for lysis under the microscope. The spheroplasts were harvested $(2,000$ r.p.m. $5 \mathrm{~min})$ and washed in 1M Sorbitol, and washed again in STC buffer (1M sorbitol; $10 \mathrm{mM} \mathrm{CaCl}$; $10 \mathrm{mM}$ Tris $\mathrm{HCl}, \mathrm{pH}$ 7.5), before resuspending in $0.5 \mathrm{ml}$ STC.

Each transformation reaction contained $100 \mu l$ spheroplasts, to which $5 \mu \mathrm{g}$ DNA was added, and incubated at room temperature for 15 min. Afterwards, $1 \mathrm{ml}$ PEG (20\%(w/v) PEG $4000 ; 10 \mathrm{mM} \mathrm{CaCl} 2$; $10 \mathrm{mM}$ Tris $\mathrm{HCl}, \mathrm{pH} 7.5$ ) was added and incubated for $15 \mathrm{~min}$. The cells were pelleted and resuspended in $150 \mu \mathrm{l}$ SOS buffer, and incubated for $2 \mathrm{hr}$ at $30^{\circ} \mathrm{C}$. A $0.1 \mathrm{ml}$ sample was added to $2 \mathrm{Oml}$ of regeneration agar, poured in a plate, and left to grow at $30^{\circ} \mathrm{C}$. Transformants took up to 3-6 days to appear.

2.8 E. COLI TRANSFORMATION (Mandel and Higa 1970).

Preparation of competent cells.

A $5 \mathrm{ml}$ culture of $E$. coli to be used for transformation was grown in $\mathrm{LB}$-medium at $37^{\circ} \mathrm{C}$ to stationary phase. The culture was diluted 100 fold into fresh LB-medium and grown up to $\mathrm{OD}_{550}=0.3$. Cells were harvested $(10,000 \mathrm{rpm}$ for $5 \mathrm{~min}$, room temperature) and resuspended in 0.5 volumes of cold $100 \mathrm{mM}$ $\mathrm{CaCl}_{2}$. After $20 \mathrm{~min}$ on ice, they were spun down, resuspended in 0.1 volumes of $100 \mathrm{mM} \mathrm{CaCl}{ }_{2}$ and kept on ice ready for use. Transformation procedure:

$200 \mu l$ of competent cells were incubated with $3 \mu l$ plasmid DNA or ligation mixture (1-100 ng) in $100 \mu \mathrm{l}$ of $10 \mathrm{mM} \mathrm{MgCl}{ }_{2}$; $10 \mathrm{mM} \mathrm{CaCl}{ }_{2} ; 10 \mathrm{mM}$ Tris $\mathrm{HCl}$, pH 7.0 , for $30 \mathrm{~min}$ on ice. The 
cells were heat-shocked at $42^{\circ} \mathrm{C}$ for $2 \mathrm{~min}$, and left to stand at room temperature for $10 \mathrm{~min}$ before incubating at $37^{\circ} \mathrm{C}$ in $1 \mathrm{ml}$ $\mathrm{LB}$-medium for $1 \mathrm{hr}$ (for $\mathrm{Amp}^{\mathrm{R}}$ ). The cells were pelleted by centrifugation and resuspended in $50 \mu \mathrm{LB}$, and plated on L-agar and $50 \mu \mathrm{g} / \mathrm{ml}$ ampicillin.

\subsection{CHEMICALS, ENZYMES AND OTHER MATERIALS.}

Chemicals of analytical grade or general purpose grade, were obtained from BDH Ltd., Poole; or Sigma. Phenol was redistilled prior to use in recombinant DNA work. Distilled water was deionized by passage over on Amberlite resin bed.

Restriction endonucleases were purchased at concentrations of 10-35 units/ $\mu$ l from Anglian Biotechnology Ltd., BCL, New England Biolabs and Pharmacia. $\mathrm{T}_{4}$ DNA ligase, E. coli RNA polymerase, Klenow fragment, SP6 RNA polymerase and RNasin were purchased from Anglian Biotechnology Ltd. $T_{4}$ DNA polymerase was from Pharmacia.

Rabbit reticulocyte lysate (messenger dependent) was from Amersham International. Radioactive nucleotides $\left[x^{-32} \mathrm{P}\right]$ dATP, $\left[\chi^{-32} \mathrm{P}\right]$ GTP and $\left[{ }^{35} \mathrm{~S}\right]$ methionine were purchased from Amersham International. [ $\left.\begin{array}{lll}1 & 25 & \mathrm{I}\end{array}\right]$ Protein A was a gift from Dr. D. Apps, Department of Biochemistry, Edinburgh, and antibodies against beta subunit of ATP synthase, mouse dihydrofolate reductase. (DHFR), and yeast hexokinase were generously provided by Prof. G. Schatz, Biocenter, Basel. Antisera against cytochrome $b_{2}$ were raised in rabbits by $G$. A. Reid.

\subsection{RECOMBINANT DNA WORK.}

DNA manipulations were performed using standard techniques 
Table 2.3. INCUBATION BUFFERS FOR RESTRICTION ENZYMES.

\begin{tabular}{|c|c|c|}
\hline $\begin{array}{l}\text { RESTRICTION } \\
\text { ENZYME }\end{array}$ & BUFFER & $\begin{array}{c}\text { TEMPERATURE } \\
\left({ }^{\circ} \mathrm{C}\right)\end{array}$ \\
\hline Bam $H I$ & MSB & $37^{\circ}$ \\
\hline Bgl II & $M S B$ & $37^{\circ}$ \\
\hline Cla I & MSB & $37^{\circ}$ \\
\hline Dra I & LSB & $37^{\circ}$ \\
\hline Eco RI & $\mathrm{HSB} / \mathrm{MSB}$ & $37^{\circ}$ \\
\hline Hind II I & MSB & $37^{\circ}$ \\
\hline Kpn I & LSB & $37^{\circ}$ \\
\hline Pst I & MSB & $37^{\circ}$ \\
\hline PVu II & $\mathrm{MSB} / \mathrm{Pvu} \mathrm{II}^{+}$ & $37^{\circ}$ \\
\hline Sac I & $\operatorname{Sac~} \mathrm{I}^{+}$ & $37^{\circ}$ \\
\hline Sal I & $\mathrm{HSB} / \mathrm{Sal} \mathrm{I}{ }^{+}$ & $37^{\circ}$ \\
\hline Sma I & Sma I & $37^{\circ}$ \\
\hline Taq I & Taq $\mathrm{I}^{+}$ & $65^{\circ}$ \\
\hline Xba I & MSB & $37^{\circ}$ \\
\hline Xho I & $\mathrm{HSB} / \mathrm{MSB}$ & $37^{\circ}$ \\
\hline
\end{tabular}

(+) Buffer specified by supplier. 
as described by Maniatis et el., (1982).

\subsubsection{Restriction Digestion of DNA.}

Restriction endonucleases were used according to the suppliers'directions. The buffers used for optimal activity of specific enzymes are shown in Table 2.3.

Digests for analytical purposes typically contained 1-2 $\mu \mathrm{g}$ DNA incubated in $20 \mu \mathrm{l}$ volume with $1-3$ units enzyme, $2 \mu \mathrm{g}$ BSA, 4 $\mu \mathrm{g}$ RNase $\mathrm{A}$ and $1 \mathrm{x}$ buffer for 2-6 hours at the appropriate temperature.

Preparative digests of DNA for cloning were typically 10-20 $\mu \mathrm{g}$ DNA incubated in $100 \mu \mathrm{l}$ with 5-10 units enzyme, $10 \mu \mathrm{g}$ BSA, 5 ug RNase $\mathrm{A}$ and $1 \mathrm{x}$ buffer, overnight at the appropriate temperature. Double digests using enzymes with different buffer requirements, were carried out individually, the DNA was phenol-chloroform extracted and ethanol precipitated between digests. Enzymes with similar requirements were used together in the digest reaction.

\subsubsection{Electrophoresis of DNA.}

Restriction digests were monitored by gel electrophoresis of $300-500 \mathrm{ng}$ sample on a $0.8 \%$ agarose gel in TBE at $75 \mathrm{~mA}$. The separated fragments were visualised under ultra violet illumination in the presence of ethidium bromide.

\subsubsection{Gene constructions.}

Cloning of DNA into plasmids and viral DNA involved the following procedure: 
(1) Digestion of DNA, followed by phenol:chloroform extraction; chloroform extraction and ethanol precipitation. The DNA was dissolved in $50 \mu \mathrm{TE}$.

(2) Separation of the DNA by gel electrophoresis (the percentage of agarose used was dependent upon the size of the desired fragment). The fragment was isolated by electroelution using the trough-dialysis membrane method. The eluate was extracted twice with 1 volume phenol:chloroform, twice with 1 volume of chloroform and precipitated with 2 volumes ethanol, and 0.1 volume $4 \mathrm{M} \mathrm{NaCl}$, at $-20^{\circ} \mathrm{C}$. After spinning the DNA down, the precipitate was dried and resuspended in TE.

(3) Ligation of DNA fragments. An aliquot of the isolated DNA was checked on a gel to estimate recovery. Ligation reactions were carried out at room temperature overnight in $10 \mu \mathrm{l}$ volumes using a 3:1 molar ratio of fragment :vector DNA, $2 \mathrm{mM} \mathrm{ATP}, 1 \mathrm{x}$ ligation buffer ( $60 \mathrm{mM}$ Tris $\mathrm{HCl}, \mathrm{pH} 7.5 ; 10 \mathrm{mM} \mathrm{MgCl} 2$ ) and $1 \mathrm{U} \mathrm{T}_{4}$ DNA ligase. The ligation mixture was used to directly transform E. coli by the $\mathrm{CaCl}_{2}$ method.

\subsubsection{Filling in reaction of Klenow fragment.}

Klenow fragment (large fragment) of $E$. coli DNA polymerase, fills in 5 , overhanging DNA ends, to give blunt ended DNA fragments or fills in gaps in open circular DNA via second strand synthesis.

DNA was digested and extracted with phenol:chloroform and ethanol precipitated. The klenow reaction was carried out at $20^{\circ} \mathrm{C}$ for $45-60 \mathrm{~min}$, using $5 \mu \mathrm{g}$ DNA in a volume of $50 \mathrm{ul}$ containing 2.5 units Klenow; $50 \mathrm{mM}$ Tris $\mathrm{Cl}$ pH $7.2 ; 10 \mathrm{mM} \quad \mathrm{MgSO}_{4}$; $1 \mathrm{mM}$ DTT, $50 \mu \mathrm{g} / \mathrm{ml}$ BSA and $0.08 \mathrm{mM}$ dNTPs. The enzyme was 
inactivated at $70^{\circ} \mathrm{C}$ for $5 \mathrm{~min}$ followed by DNA extraction and precipitation.

\subsubsection{Removal of $3^{\prime}$ DNA extensions with $T_{4}$ DNA polymerase} (Maniatis et al., 1982).

$\mathrm{T}_{4}$ DNA polymerase, in the presence of dNTPs will trim $3^{\prime}$ overhangs generated by restriction cleavage using enzymes such as SacI, to give blunt ended DNA.

The trimming reaction was performed on digested DNA, after extraction and ethanol precipitation. 1-5 $\mu \mathrm{g}$ of DNA was incubated for $5 \mathrm{~min}$ at $37^{\circ} \mathrm{C}$ with $2.5 \mathrm{U} \mathrm{T}_{\mathbf{4}}$ DNA polymerase in a 20 $\mu \mathrm{l}$ volume containing $0.2 \mathrm{mM}$ dNTPs, $33 \mathrm{mM}$ Tris acetate ( $\mathrm{pH} \quad 7.9$ ), $66 \mathrm{mM} \mathrm{K}$. acetate, $10 \mathrm{mM} \mathrm{Mg}$. acetate, $0.5 \mathrm{mM} \mathrm{DTT}$ and $0.1 \mathrm{mg} / \mathrm{ml}$ BSA. The enzyme was inactivated with $1 \mu \mathrm{l}$ of $0.5 \mathrm{M}$ EDTA, extracted with phenol:chloroform, chloroform and precipitated with ethanol. The pellet was washed in $70 \%$ ethanol and dried.

\subsection{DNA SEQUENCING BY DIDEOXY CHAIN TERMINATION METHOD.}

(Sanger et al., 1977).

\subsubsection{Plasmid sequencing.}

Plasmid sequencing was performed according to Wallace et al., (1981) with minor modifications.

Plasmid DNA was prepared by alkaline lysis (Birnboim and Doly, 1979) followed by RNase A digestion, and DNA extraction and precipitation with isopropanol; or $\mathrm{CsCl}$-ethidium bromide buoyant density gradient purification.

Two oligonucleotides used as sequence primers, were synthesised. PDS1, an 18mer (GATTCAAATTGTTGAGCGG) hybridises to plasmid pDS6 just before the insertion site and allowed the 
sequence to be read from the start of the insert. BETA1, an 18mer (CAGCTGAGGCCATACATC) hybridises to the ATP2 gene close to the PruII site and was used to sequence the missense DNA strand.

$2 \mu \mathrm{g}$ of each DNA to be sequenced was ethanol precipitated and resuspended in $10 \mu \mathrm{l}$ of sequencing buffer $(60 \mathrm{mM} \mathrm{NaCl} ; 50 \mathrm{mM}$ Tris $\mathrm{HCl}$, pH $7.5 ; 7 \mathrm{mM} \mathrm{Mg}(\mathrm{Ac})_{2} ; 7 \mathrm{mM}$ DTT. The DNA was either initially cut with 3 units Pst1 for $60 \mathrm{~min} 37^{\circ} \mathrm{C}$, or immediately added to 6 pmol oligonucleotide primer. $2-3 \mu \mathrm{l}$ of a $20-30 \mu \mathrm{g} / \mathrm{ml}$ stock solution of PDSI or BETA1 was used. The primer and DNA template mixture was boiled $3 \mathrm{~min}$ in Eppendorf tubes or glass capillaries and immediately cooled in ice water for $30 \mathrm{~min}$. Further annealing at $37^{\circ} \mathrm{C}$ for $30 \mathrm{~min}$ was used if the plasmid had been digested. The DNA was directly used for sequencing by the dideoxynucleotide chain-termination protocol (2.11.3), with all reactions carried out at $37^{\circ} \mathrm{C}$.

2.11.2. Dideoxynucleotide chain-termination sequencing. (Sanger et al., 1977).

Preparation of M13 single stranded DNA for sequencing templates. E.coli strain NM522 was transformed with M13 RF DNA containing an ATP2 insert. A colourless plaque was picked and grown up overnight $37^{\circ} \mathrm{C}$ in $3 \mathrm{ml} \mathrm{LB}$ medium with good aeration. The culture was transferred to Eppendorf tubes, and spun 5 min in the microfuge. After centrifugation, the culture supernatant was added to $300 \mu \mathrm{l} 2.5 \mathrm{M} \mathrm{NaCl} ; 20 \%$ PEG 6000 , mixed well and left $15 \mathrm{~min}$ at room temperature. The contents were spun $5 \mathrm{~min}$, and the supernatant was aspirated to remove all the PEG. The phage pellet was stored at $4^{\circ} \mathrm{C}$ or taken up in $100 \mu \mathrm{LTE}$. The protein coat was removed by extraction with $50 \mu \mathrm{l}$ phenol, vortexed 10 
seconds and allowed to stand $5 \mathrm{~min}$, revortexed and spun for 1 min. The supernatant was transferred to a clean tube and $0.5 \mathrm{ml}$ diethylether added, vortexed and spun again. The DNA was ethanol precipitated with $10 \mu \mathrm{l} 3 \mathrm{M} \mathrm{Na}$. acetate $\mathrm{pH} 5,250 \mu \mathrm{l}$ ethanol, left at $-70^{\circ} \mathrm{C}$ for $60 \mathrm{~min}$ and spun $5 \mathrm{~min}$ at $4^{\circ} \mathrm{C}$. The pellet was dried and dissolved in $50 \mu \mathrm{TE}$.

\subsubsection{Sequencing of M13 DNA Template.}

DNA was sequenced by the following procedure:

Annealing of template to primer: $22 \mu l$ of pentadecamer primer $(2.5 \mu \mathrm{g} / \mathrm{ml})$ was mixed with $16.5 \mu \mathrm{l} 0.1 \mathrm{M}$ Tris $\mathrm{HCl} \mathrm{pH} 8.0,50 \mathrm{mM}$ $\mathrm{MgCl}_{2}, 4 \mu \mathrm{l}$ of this was mixed with $8 \mu \mathrm{l}$ DNA template, and heated at $100^{\circ} \mathrm{C}$ for $3 \mathrm{~min}$ in sealed capillary tubes. The DNA was cooled slowly to room temperature.

Sequencing reactions: The template/primer mixture was aliquoted $(2 \mu \mathrm{l})$ into each of four $1.5 \mathrm{ml}$ tubes (TCGA reactions). Onto the side of the appropriate tubes, $2 \mu \mathrm{l}$ of termination mixes was pipetted. From a stock solution of 10 units Klenow fragment mixed with 40 microcuries $\left[{ }^{32} \mathrm{P}\right] \propto$ dATP; $(400 \mathrm{Ci} / \mathrm{mmol})$, in a volume of $90 \mu \mathrm{l} 10 \mathrm{mM}$ Tris, $\mathrm{pH} 8 ; 2 \mu \mathrm{l}$ aliquots were added to the tubes. The reaction was started by spinning briefly, and incubated at $20-25^{\circ} \mathrm{C}$, for $15 \mathrm{~min}$. Afterwards, $2 \mu \mathrm{l}$ of chase mixture (0.5 mM dNTPs) was added, and chased for a further 20 $\min$. The samples were denatured by adding $4 \mu \mathrm{l}$ formamide/dye mix and boiled $3 \mathrm{~min}$.

Gel electrophoresis: A sample of 2-5 $\mu \mathrm{l}$ was immediately loaded onto a sucrose/urea gradient polyacrylamide gel, and run at $30 \mathrm{~W}$ for 2 hours. 
After electrophoresis, the gel was transferred onto 3MM Whatman filter paper, washed free of urea and dried under vacuum.

\subsection{BISULPHITE IN VITRO MUTAGENESIS.}

The in vitro mutagenesis protocols used in this study were essentially those of Shortle and Nathans (1978) and Kalderon et al., (1982), with minor modifications.

Plasmid DNA was prepared by alkaline lysis (Birnboim and Doly, 1979) followed by ethidium bromide-CsCl buoyant density gradient centrifugation.

\section{(1) Gapped circle DNA preparation.}

$14 \mu \mathrm{g}$ each of plasmids pGR2O9 and pGR2O7 were linearised by restriction digestion, phenol:chloroform extracted and ethanol precipitated. The digestion was repeated to ensure total linearisation.

The DNA was resuspended in $120 \mu \mathrm{l}$ water, mixed with $19.2 \mu \mathrm{l}$ $1 \mathrm{M} \mathrm{NaOH}$, and left at room temperature for $10 \mathrm{~min}$. Afterwards, the DNA was renatured by sequential addition of $1120 \mu \mathrm{l} \mathrm{H}_{2} \mathrm{O}, 160$ $\mu \mathrm{l} 0.5 \mathrm{M}$ Tris $\mathrm{HCl} \mathrm{pH} 8,192 \mu \mathrm{l} 100 \mathrm{mM} \mathrm{HCl}$, mixed and incubated for 2 hours at $63^{\circ} \mathrm{C}$. After precipitation with ethanol, twice, the pellet was resuspended in $28 \mu \mathrm{l}$ deionised water.

(2) Mutagenesis: Approximately $1 \mathrm{ug}$ of heteroduplex DNA was used for mutagenesis. $4 \mathrm{M} \mathrm{Na}$. bisulphite $\mathrm{pH} 6.0$ was prepared fresh with deionised water. For mutagenesis, 3 volumes of bisulphite was added to 1 volume DNA to give a final concentration of $10-20 \mu \mathrm{g} / \mathrm{ml}$, in $3 \mathrm{M} \mathrm{Na}$. bisulphite $\mathrm{pH} 6.0,15 \mathrm{mM}$ $\mathrm{NaCl}, 1.5 \mathrm{mM} \mathrm{Na}$. citrate and $2 \mathrm{mM}$ quinol, with all components at 
$\mathrm{O}^{\circ} \mathrm{C}$ when mixed.

The reaction was continued from 30 to $240 \mathrm{~min}$, before terminating by dialysis against:

(1) 1000 vol $5 \mathrm{mM} \mathrm{KPi} \mathrm{pH} 6.8 ; 0.5 \mathrm{mM}$ quinol at $0^{\circ} \mathrm{C}$ for $2 \mathrm{hr}$.

(2) Repeated (1).

(3) 1000 vol of $5 \mathrm{mM} \mathrm{KPi} \mathrm{pH} 6.8$ at $\circ^{\circ} \mathrm{C}$ for $4 \mathrm{hr}$.

(4) 1000 vol of 0.2 Tris $\mathrm{HCl} \mathrm{pH} 9.2,50 \mathrm{mM} \mathrm{NaCl}, 2 \mathrm{mM}$ EDTA at $37{ }^{\circ} \mathrm{C}$ for $16-24 \mathrm{~h}$.

(5) 1000 vol $2 \mathrm{mM}$ Tris $\mathrm{HCl} \mathrm{pH} 8.0,2 \mathrm{mM} \mathrm{NaCl}, 0.2 \mathrm{mM}$ EDTA at $4^{\circ} \mathrm{C} 6-12 \mathrm{hr}$.

NB: The water used to prepare the first four dialysis buffers was degassed by vigorous boiling and autoclaved. Dialysis was performed in the dark.

The DNA was precipitated first with ethanol, followed by a second precipitation using isopropanol, to remove bisulphite and salt. An aliquot of $3 \mu \mathrm{l}$ from $20 \mu \mathrm{l}$ DNA solution was used to transform $E$. coli $\mathrm{BD} 1528$ by the $\mathrm{CaCl}_{2}$ method. Transformants were selected for ampicillin resistance, and screened by restriction digestion and DNA sequencing.

\subsection{TCA EXTRACTION OF PROTEINS FROM S. CEREVISAE.}

Yeast was grown to $\mathrm{OD}_{600}=0.6$, in $50 \mathrm{ml}$ liquid culture at $30^{\circ} \mathrm{C}$. Cells were harvested by centrifugation ( $5000 \mathrm{rpm}, 5 \mathrm{~min}$ ) and proteins extracted by vortexing the cells with glass beads (mesh 40) in 10\% TCA. The protein precipitate was spun down ( $8000 \mathrm{rpm}, 5 \mathrm{~min}$ ), washed with ethanol, dried and resuspended in sample buffer $10.15 \mathrm{M}$ Tris $\mathrm{HCl} \mathrm{pH} 6.8,6 \%$ SDS, $6 \mathrm{mM}$ EDTA, $30 \%$ glycerol, $0.03 \%$ bromophenol blue, $1 \%$ 2-mercaptoethanol) at $1 / 50$ th to $1 / 100$ th of the original culture volume, and 
neutralised with $1 \mathrm{M}$ Tris base. Aliquots were boiled for $3 \mathrm{~min}$, clarified by centrifugation, electrophoresed on $12 \%$ polyacrylamide gels in the presence of SDS and stained with Coomassie Brilliant Blue or PAGE Blue. Samples were stored at $-70^{\circ} \mathrm{C}$.

\subsection{WESTERN BLOT ANALYSIS OF PROTEINS.}

Published techniques of electrophoretic blotting of proteins onto either nitrocellulose or Nylon membrane filters; immunodecoration of filters using rabbit antibodies and [ ${ }^{1} 25 \mathrm{I}$ ] Protein A or Horseradish peroxidase conjugated second antibody, were used with minor modifications.

Electrophoretic transfer of proteins onto membrane filters:

Proteins were separated by SDS PAGE, and transferred onto nitrocellulose in $25 \mathrm{mM}$ Tris $\mathrm{HCl} \mathrm{pH} 8.3,150 \mathrm{mM}$ glycine, 20\% methanol; or onto Hybond-N Nylon in $25 \mathrm{mM}$ Tris $\mathrm{HCl} \mathrm{pH} 8.3,150$ mM glycine, using an LKB Transphor apparatus for 1-2 hr at $1 \mathrm{~A}$. Immuno-detection of specific proteins:

After transfer, the filter was blocked in TBS with $20 \%$ Oxoid skimmed milk powder ( overnight at $4^{\circ} \mathrm{C}$ ), before incubating with $30 \mu l$ rabbit antiserum against beta subunit, yeast hexokinase or cytochrome $b_{2}$ in $5 \%$ milk powder $(w / v)$ in TBS for $4 \mathrm{hrs}$ at $20-37^{\circ} \mathrm{C}$. Excess antibody was washed of $\mathrm{f}$ in TBS, before incubation with the second antibody for $1 \mathrm{hr}$ at room temperature.

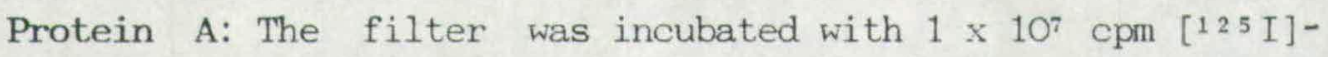
Protein A in $5 \%$ milk powder in TBS and afterwards washed in TBS (4) $\mathrm{x} 5 \mathrm{~min}$ ). Specific radioactive bands were detected by 
autoradiography (exposure of the filter to Agfa X-ray film with an intensifying screen at $-70^{\circ} \mathrm{C}$ ).

Horseradish peroxidase conjugated second antibody: The filter was incubated with $20 \mu l$ peroxidase-conjugated pig anti-rabbit IgG in $5 \%$ milk powder in TBS at $20-37^{\circ} \mathrm{C}$ and washed in TBS. The HP-mediated reaction was developed using a freshly prepared solution of $0.03 \% \mathrm{H}_{2} \mathrm{O}_{2}, 10 \mathrm{mM}$ imidazole $\mathrm{pH} 7.4$, and $2.5 \mathrm{mg}$ o-dianisidine, until brown bands were visible. After stopping the reaction in water, the filter was dried and photographed.

\subsection{IN VITRO TRANSCRIPTION-TRANSLATION.}

\subsubsection{In vitro transcription using $\mathrm{E}$. coli RNA polymerase.}

Single species of RNA were transcribed from genes cloned behind the bacteriophage $T_{5}$ promoter in plasmids pDS6 and pDS7, using E. coli RNA polymerase (Stueber et al., 1984).

$6.5 \mu \mathrm{g}$ of $\mathrm{CsCl}$ purified plasmid DNA was incubated in a volume of $10 \mu \mathrm{l}$ containing $0.1 \mathrm{mM} 7 \mathrm{mGpppA}$ (cap analog); $20 \mathrm{mM}$ HEPES-KOH $\mathrm{pH} \quad 7.9 ; 10 \mathrm{mM}$ Mg. acetate; $200 \mathrm{mM} \mathrm{K}$. acetate; $5 \mathrm{mM}$ DTT; $0.2 \mathrm{mM}$ spermidine; $13 \mathrm{U}$ RNasin; $0.5 \mathrm{mM}$ each of GTP, CTP, and UTP; and $1 \mathrm{U}$ of E.coli RNA polymerase for $3 \mathrm{~min}$ at $37^{\circ} \mathrm{C}$. After

$3 \mathrm{~min}, 0.5 \mu \mathrm{l}$ of $20 \mathrm{mM}$ ATP was added, and incubated for a further $10 \mathrm{~min}$. The reaction was stopped by chilling on ice, and stored at $-70^{\circ} \mathrm{C}$.

2.15.2 In vitro transcription of RNA using SP6 RNA polymerase.

Capped and uncapped RNA of high purity was transcribed from genes cloned behind the SP6 promoter in plasmid pSP65, using Salmonella typhimurium SP6 RNA polymerase (Krieg and Melton, 
1984).

Incubation was carried out for $90 \mathrm{~min}$ at $37^{\circ} \mathrm{C}$ in a reaction volume of $10 \mu \mathrm{l}$ containing: $40 \mathrm{mM}$ Tris $\mathrm{Cl}, \mathrm{pH} 7.5 ; 6 \mathrm{mM} \mathrm{MgCl}_{2} ; 4$ $\mathrm{mM}$ spermidine; $500 \mu \mathrm{M}$ each of GTP, CTP, ATP, and UTP; $10 \mathrm{mM}$ DTT; BSA $(100 \mu \mathrm{g} / \mathrm{ml}) ; 7.5$ units RNasin; $0.5 \mu \mathrm{g}$ linearised DNA and 1.25 units of SP6 RNA polymerase.

The DNA used in the reaction was first extracted with phenol:chloroform and precipitated with ethanol.

\subsubsection{In vitro translation.}

The transcription mixture was used directly for translation in vitro in a nuclease treated (messenger dependent) rabbit reticulocyte lysate (Pelham and Jackson, 1978).

Incubation was carried out at $30^{\circ} \mathrm{C}$ for $60 \mathrm{~min}$ in a reaction volume of $10 \mu \mathrm{l}$ containing $8 \mu \mathrm{l}$ rabbit reticulocyte lysate; $2 \mu \mathrm{l}$ RNA and $5 \mu \mathrm{Ci}\left[{ }^{35} \mathrm{~S}\right]$ methionine added. The translation products were kept on ice ready for use or stored at $-70^{\circ} \mathrm{C}$.

\subsection{PREPARATION OF YEAST MITOCHONDRIA.}

Mitochondria were prepared from yeast D273-10B grown in 2 litre batch culture of $2 \%$ lactate medium at $30^{\circ} \mathrm{C}$ overnight to $A_{600}=0.5-0.6$. (Daum et al., 1982)

Cells were harvested $(5000 \mathrm{rpm} 5 \mathrm{~min})$ and washed in distilled water. The cell pellet was resuspended to $0.5 \mathrm{~g}$ wet cells/ml in $0.1 \mathrm{M}$ Tris $\mathrm{SO}_{4} \mathrm{pH} 9.3 ; 10 \mathrm{mM}$ DTT and incubated for 10 min at $30^{\circ} \mathrm{C}$. After recentrifuging, the pellet was washed once in $1.2 \mathrm{M}$ sorbitol and finally resuspended to $0.15 \mathrm{~g}$ wet cell weight/ml in $1.2 \mathrm{M}$ sorbitol; $20 \mathrm{mM} \mathrm{KPi} \mathrm{pH} 7.4$. Zymolase digestion 
was carried out using $5 \mathrm{mg}$ Zymolase $5000 / \mathrm{g}$ cell weight at $30^{\circ} \mathrm{C}$ until spheroplasts were formed ( 50-60 min). Spheroplasts were collected ( $3500 \mathrm{rpm}, 5 \mathrm{~min})$ and washed twice in $1.2 \mathrm{M}$ sorbitol by careful resuspension.

The following procedures were carried out at $0-4^{\circ} \mathrm{C}$. After the final wash, the spheroplast pellet was resuspended to 2 volumes per weight in breaking buffer (0.6M mannitol; $20 \mathrm{mM}$ HEPES-KOH $\mathrm{pH} 7.4 ; 1 \mathrm{mM}$ PMSF) The PMSF was made fresh each time as a $100 \mathrm{mM}$ stock in absolute ethanol. The suspension was homogenised in a Dounce Homogeniser using 10 strokes with pestle B. One volume of breaking buffer was added and the homogenate centrifuged ( $3500 \mathrm{rpm}, 5 \mathrm{~min})$. The supernatant was kept and the pellet rehomogenised and centrifuged. The crude mitochondria were pelleted by high speed centrifugation of the supernatant (9000 $\mathrm{rpm}, 10 \mathrm{~min}$ ) and resupended in breaking buffer. The low speed centrifugation was repeated to remove nuclei and cell contaminants, and the supernatant was respun at high speed to obtain the mitochondria. PMSF was removed by washing in $0.6 \mathrm{M}$ Mannitol; $20 \mathrm{mM}$ HEPES- $\mathrm{KOH} \mathrm{pH} 7.4$, and reisolation of the mitochondria. The mitochondria were resuspended to $2-3 \mathrm{mg} / \mathrm{ml}$ in the same buffer.

Protein concentrations were determined from $A_{2}$ so readings using $10 \mu \mathrm{l}$ samples in $1 \mathrm{ml} 0.6 \% \mathrm{SDS}$, and calculated from the approximation that $\mathrm{A}_{2} 80$ of $0.2=10 \mathrm{mg} / \mathrm{ml}$.

2.17. IN VITRO TRANSPORT INTO ISOLATED YEAST MITOCHONDRIA.

In vitro transport of radiolabelled polypeptides into isolated yeast mitochondria, was according to Gasser et al., 
(1982b) with minor alterations.

Mitochondria were freshly prepared from S. cerevisae $\mathrm{D} 273-1 \mathrm{OB}$, grown in $2 \%$ lactate medium to $\mathrm{A}_{600}=0.5-0.6$. (Daum et al., 1982). The mitochondrial pellet was resuspended to 2-3 $\mathrm{mg} / \mathrm{ml}$ mitochondrial protein in $0.6 \mathrm{M}$ mannitol; $20 \mathrm{mM}$ HEPES-KOH pH 7.4.

In vitro transport was carried out for $30 \mathrm{~min}$ at $28^{\circ} \mathrm{C}$ in a $300 \mu \mathrm{l}$ volume containing: $210 \mu \mathrm{g}$ mitochondrial protein; $40 \mathrm{mM}$ $\mathrm{KCl} ; 1 \mathrm{mM} \mathrm{DTT} ; 1 \mathrm{mM}$ ATP; $1 \mathrm{mM} \mathrm{MgCl}_{2} ; 5 \mathrm{mM} \mathrm{K}$.PEP; 0.6M Mannitol; $20 \mathrm{mM}$ HEPES-KOH $\mathrm{pH} 7.4$ and $6 \mathrm{U}$ pyruvate kinase and $16.5 \mu \mathrm{l}$ translation products.

The fate of the radiolabelled precursor polypeptides was followed by protease protection studies. Three aliquots of equal volume were taken and incubated for $15 \mathrm{~min}\left(\mathrm{O}^{\circ} \mathrm{C}\right)$, either without proteinase $\mathrm{K}$, or with $10 \mathrm{\mu g} / \mathrm{ml}$ proteinase $\mathrm{K}$ in the absence or presence of $0.3 \%$ Triton $\mathrm{X}-100$. After $15 \mathrm{~min}$, PMSF was added (from a fresh $100 \mathrm{mM}$ stock in absolute ethanol) to a final concentration of $1 \mathrm{mM}$. The mitochondria were reisolated by spinning in a microfuge for $10 \mathrm{~min}$ at $4^{\circ} \mathrm{C}$, washed in $0.6 \mathrm{M}$ mannitol; $20 \mathrm{mM}$ HEPES-KOH $\mathrm{pH} 7.4$ and reisolated. Proteins from the mitochondrial pellet and extra-mitochondrial supernatant were precipitated by $10 \%$ TCA, and pelleted by centrifugation 15 min in microfuge at room temperature).

SDS PAGE and Fluorography.

The protein precipitate was resuspended in $20 \mu \mathrm{l}$ sample buffer and electrophoresed on a $12 \%$ polyacrylamide gel in the presence of SDS, at $200 \mathrm{~V}$ or $50 \mathrm{~mA}$. After electrophoresis, the proteins were fixed in a volume of $100 \mathrm{ml}$ hot $5 \% \mathrm{TCA}$. The gel was washed in water, neutralised with $\mathrm{NaOH}$, washed again in 
water then incubated with $100 \mathrm{ml}$ of $1 \mathrm{M}$ sodium salicylate for 30 min at room temperature. The excess salicylate was washed off with water, and the gel dried under vacuum. Radiolabelled proteins were visualised by exposure of the dried gel to X-ray film at $-70^{\circ} \mathrm{C}$ for $1-7$ days.

\subsection{PREPARATION OF RADIOLABELLLED MATURE AND PRECURSOR} POLYPEPTIDES.

${ }^{35} \mathrm{~S}$ labelled polypeptides were prepared esssentially according to Reid and Schatz (1982a).

A $5 \mathrm{ml}$ culture of D273-10B grown in sulphate-free medium at $30^{\circ} \mathrm{C}$, was used as inoculum for $50 \mathrm{ml}$ of the same medium $11: 100$ dilution). The cells were grown to $A_{600}=0.2$, and resuspended to $0.1 \mathrm{~g}$ wet weight $/ \mathrm{ml}$ in $40 \mathrm{mM} \mathrm{KPi} \mathrm{pH} 6.0$ \& $0.5 \%$ lactate $\mathrm{pH}$ 6.0 or $0.5 \%$ glucose. Precursor protein was accumulated by adding CCCP to a final concentration of $20 \mu \mathrm{M}$ (from a $2 \mathrm{mM}$ stock in absolute ethanol) before $50 \mu \mathrm{Ci}\left[{ }^{35} \mathrm{~S}\right]$ methionine was added and the cells incubated for approximately $60 \mathrm{~min}$ until there was $10-20 \%$ incorporated TCA precipitable counts. Labelling of mature proteins was essentially the same except CCCP was omitted. Proteins were extracted by TCA and glass beads, and resuspended in $0.5 \mathrm{ml}$ sample buffer. The samples were boiled for $3 \mathrm{~min}$ in Eppendorf tubes, and centrifuged for $10 \mathrm{~min}$. The supernatant transferred to Erlenmeyer bottles, to which $15 \mathrm{ml}$ TNET and $30 \mu \mathrm{l}$ F1 $\beta$ antibody was added and left overnight at $4^{\circ} \mathrm{C} .2 \mathrm{mg}$ of unswollen Protein A sepharose (Sigma) was added to each sample and mixed by rotation for 2 hours. The contents were transferred to $30 \mathrm{ml}$ Corex tubes and centrifuged at 3,000 rpm in an MSE benchtop centrifuge for $5 \mathrm{~min}$. The supernatant was removed and 
kept $\left(4^{\circ} \mathrm{C}\right)$ for other immunoprecipitations, whilst the protein $\mathrm{A}$ sepharose was resuspended in $1 \mathrm{ml}$ TNET and transferred to an Eppendorf tube. Unbound polypeptides were removed by washing several times in TNET, before resuspending the immunoprecipitate in SDS sample buffer. The sample was kept at $-70^{\circ} \mathrm{C}$ ready for use.

\subsection{PULSE LABELLING OF YEAST PROTEINS IN VIVO.}

Pulse label studies on yeast was performed according to van Loon et al., (1986) with minor modifications.

Yeast transformants were grown at $30^{\circ} \mathrm{C}$ in $10 \mathrm{ml}$ sulphate free minimal medium to $\mathrm{OD}_{600}=1-2$. The cells were diluted ten fold in fresh medium supplemented with $0.5 \%$ yeast extract and $1 \%$ bactopeptone, and grown for $4-5 \mathrm{hr}$. From each culture, $20 \mathrm{OD}$ units of cells were harvested and resuspended in $2 \mathrm{ml}$ of $50 \mathrm{mM}$ KPi pH $6,0.5 \%$ glucose, $0.01 \%$ yeast extract in a $20 \mathrm{ml}$ Erlenmyer bottle. 100 microcuries of $\left[{ }^{35} \mathrm{~S}\right]$ methionine was added and after $7 \mathrm{~min}, 100 \mu \mathrm{g} / \mathrm{ml}$ cycloheximide was added. The radiolabelled proteins were chased with $2 \mathrm{mM}$ methionine for $100 \mathrm{~min}$, during which time aliquots of $200 \mu \mathrm{l}$ cells were removed and put into TCA ( $5 \%$ final concentration) and kept on ice.

Proteins were extracted according to Yaffe and Schatz (1984). The TCA was removed by centrifugation and the cell pellet was resuspended in $100 \mu \mathrm{l}$ water. $16 \mu \mathrm{l}$ of fresh $2.85 \mathrm{M}$ $\mathrm{NaOH} ; 7.4 \%$ 2-mercaptoethanol was added and kept on ice for 10 min, followed by the addition of $8 \mu \mathrm{ll} 100 \% \mathrm{TCA}$. After $10 \mathrm{~min}$ on ice, the cells were spun for $2 \mathrm{~min}$ in a microfuge, and the pellets were washed with $150 \mu l$ cold acetone, spun again and 
aspirated. The TCA precipitates were dried under vacuum and solubilised in $0.5 \mathrm{ml} 5 \%$ SDS by boiling for $3 \mathrm{~min}$. The supernatant was transferred to an Erlenmeyer bottle and diluted with $15 \mathrm{ml}$ TNET. Immunoprecipitation was carried out as described in section 2.18 . 
RESULTS

CHAPTER 3. ISOLATION AND CHARACTERISATION

OF THE ATP2 GENE ENCODING

BETA SUBUNIT OF YEAST ATP SYNTHASE. 
RESULTS

3. ISOLATION AND CHARACTERISATION OF THE ATP2 GENE ENCODING BETA SUBUNIT OF YEAST ATP SYNTHASE.

\subsection{CLONING AND CHARACTERISATION OF THE ATP2 GENE.}

The structural gene for the beta subunit of F1-ATPase, designated ATP2, was originally isolated from a yeast genomic DNA library, as a $2.65 \mathrm{~kb}$ fragment in the yeast/E. coli shuttle vector pFL1 (G. A. Reid, unpublished). The procedure used to screen the library, for nuclear genes encoding mitochondrial proteins such as the ATP2 gene, was by a RNA hybridisation-competition assay (van Loon et al., 1983). Clones carrying genes for mitochondrial proteins give a strong hybridisation signal if challenged with total mRNA from yeast cells in which mitochondrial formation has been induced by growth in the absence of glucose. A further screening of the clones which had selectively hybridised was carried out by hybrid selected translation and immunoprecipitation with specific antisera against individual mitochondrial proteins. The clone pFL1-11-3, was shown to contain the entire ATP2 gene because overexpression of the precursor polypeptide to the beta subunit of F1-ATPase was seen after transformation in yeast.

In a separate study, the ATP2 gene was cloned by direct complementation of a Saccharomyces cerevisae leu ${ }^{-}$pet mutant, lacking detectable F1-ATPase activity using a Sau3A 
Fiqure 3.1. RESTRICTION MAP OF THE ATP2 GENE ENCODING
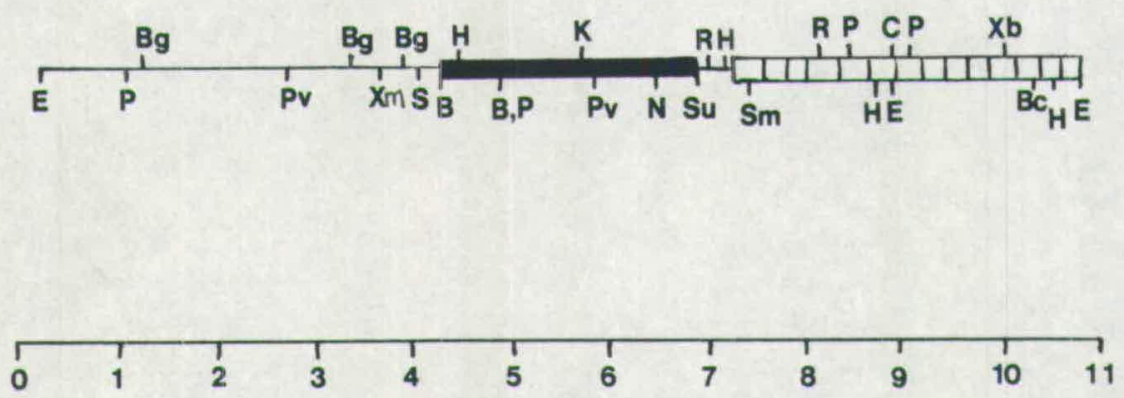

Yeast sequences inserted into the unique BamHI site of pFL 1 are indicated by the heavy line. The thin lines represent flanking pBR322 sequences of PFL 1 into which the insertion was made. The boxed lines are the URA 3 and 2 micron $(\mu)$ sequences. The units across the bottom of the figure are kilo bases. No restriction sites were found for SmaI, SalI, EcoRI and Xhol which cut in the insert encoding beta subunit.

Restriction endonuclease sites are as follows: Xm, XmaIII; $\mathbf{X b}$, XbaI; Sm, SmaI; s, SalI; Su, Sau3A; Pv, PvuII; P, PstI; $\mathbf{N}, \mathrm{NruI} ; \mathrm{K}, \mathrm{KpnI} ; \mathrm{H}, \mathrm{HindIII} ; \mathbf{R}$, ECoRV; E, EcoRI; Bg, BgII; Bc, BclI; B, BamHI; C, ClaI. 
yeast genomic library constructed in the yeast episomal plasmid YEp13 (Saltzgaber-Muller et al., 1983). The complementing plasmid pJ14 was further analysed by hybrid selection of mRNA from total yeast RNA and in vitro translation and immunopreciptiation with antisera to beta subunit.

Restriction analysis of plasmid pFL1-11-3 (as shown in figure 3.1) demonstrated that the $2.65 \mathrm{~kb}$ Sau3A fragment cloned into the unique BamHI site of pFL1, was identical to the ATP2 gene partially characterised by Saltzgaber-Muller and coworkers (1983). Both plasmids pJ14 and pFL1-11-3 were used to study the gene in vitro and in vivo.

Previous studies on mitochondrial protein import required the isolation of specific precursor polypeptides by in vitro translation of total RNA followed by an immunoprecipitation step. Preparation of the radiochemically pure precursor polypeptide (of high specific radioactivity) is lengthy because the desired mRNA is usually a rare species in the total RNA population. Therefore the efficiency of isotope incorporation into the corresponding protein is reduced compared to that of a preparation containing one RNA species. Recent advances in in vitro transcription and translation techniques have made possible the preparation of relatively pure RNA (Krieg and Melton, 1984; Stueber et al., 1984). The protein can be manipulated at the gene level by in vitro mutagenesis, cloned into transcription vectors and expressed in vitro. The SP6 in vitro transcription system (Butler and Chamberlin, 1982) was chosen for the synthesis of RNA encoding the beta subunit of F1-ATPase. 


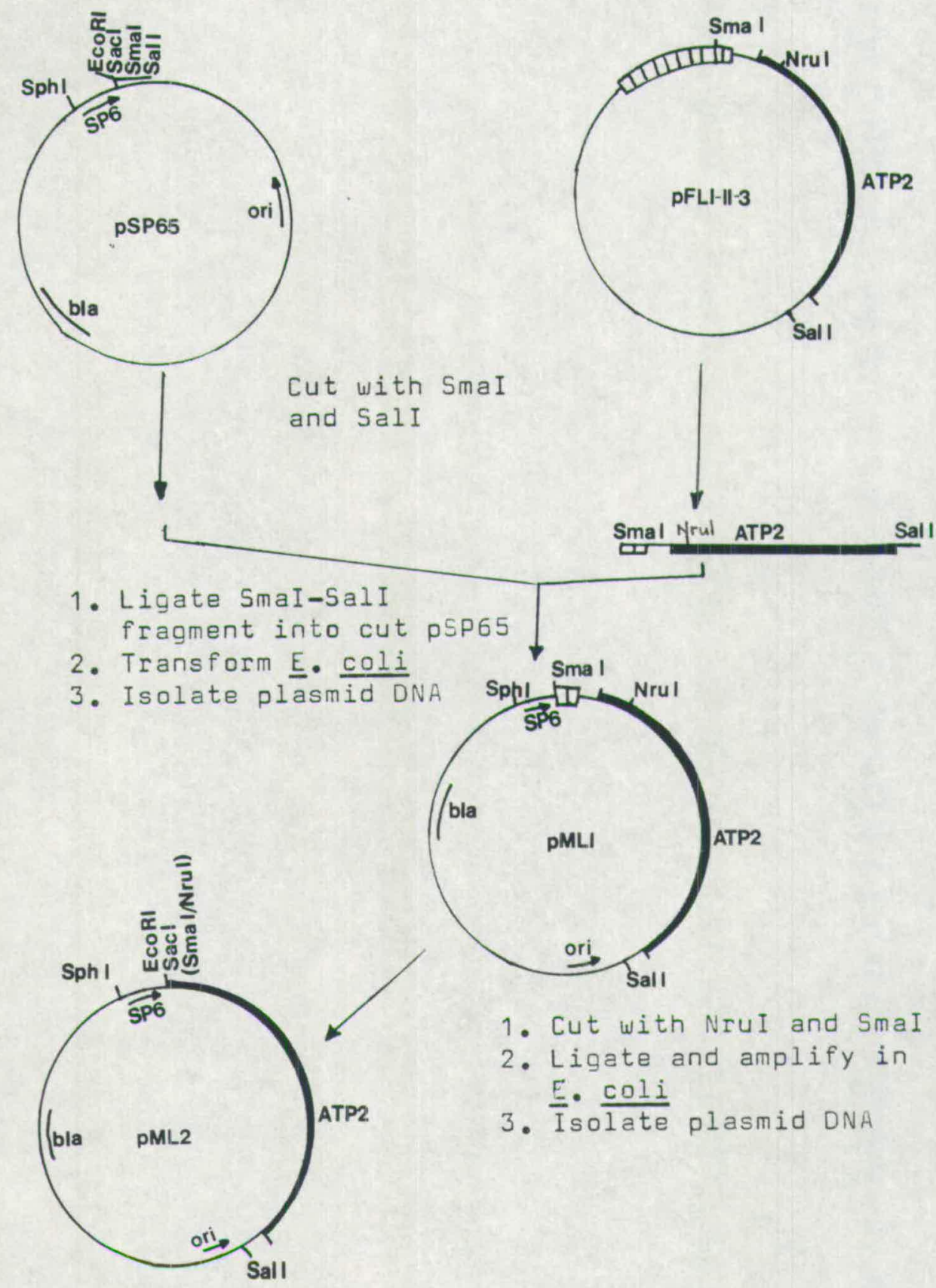

Plasmid PML 1 contains the entire ATP2 gene, and flanking pBR322 and URA3 sequences cloned behind the SPG promoter in pSP65. Deletion of the one kilobase fragment between NruI-SmaI in PML 1 generates plasmid PML2. The thick lines are the yeast ATP2 sequences, and the flanking URA 3 sequence and p $\overline{B R 3} 22$ DNA are represented by boxed and thin lines respectively. 


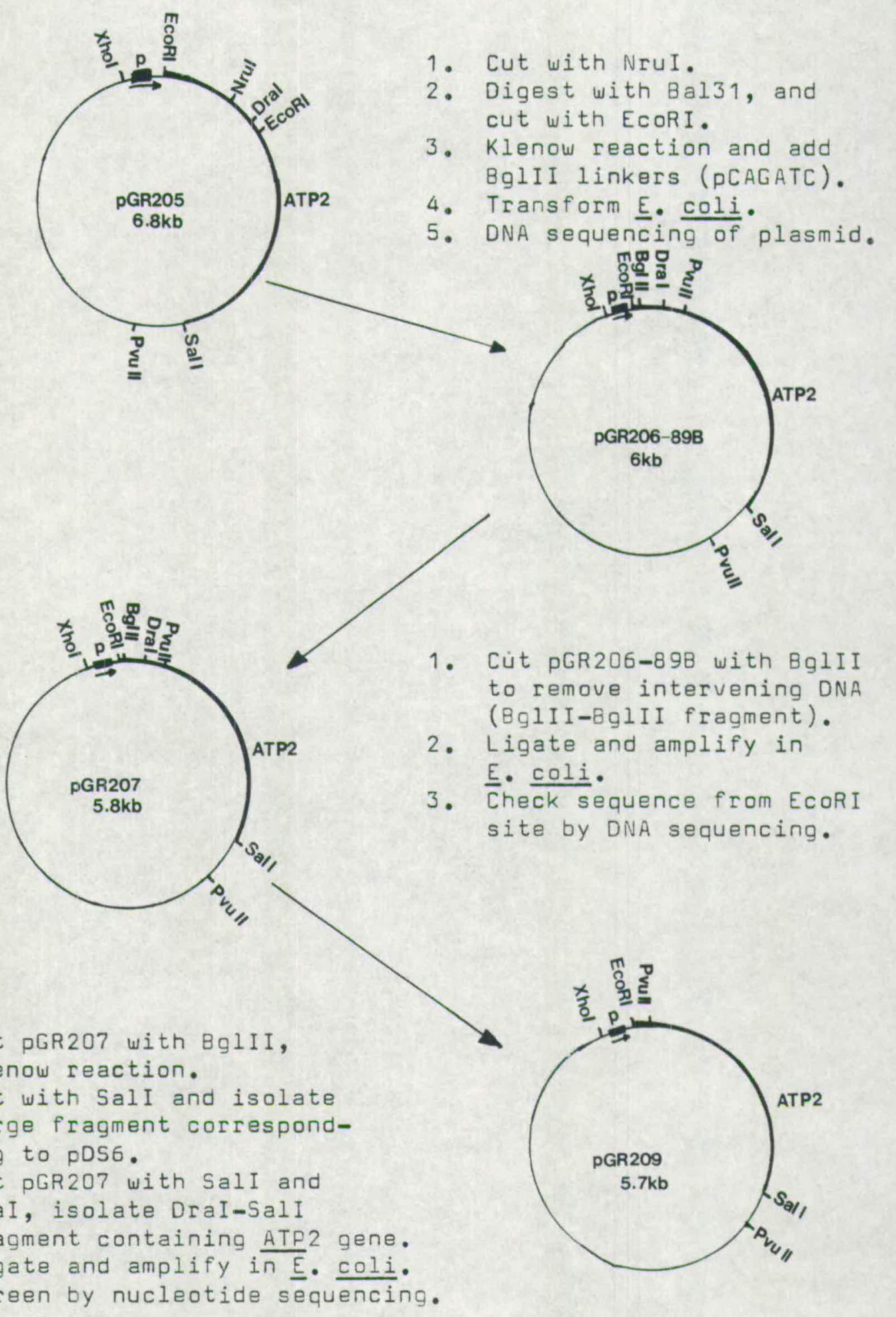


The entire ATP2 gene (including flanking URA3 and pBR322 sequences derived from pFL1) was subcloned as a $3.6 \mathrm{~kb}$ SmaI-SalI fragment of pFL1-11-3, into the polylinker region of pSP65 (figure 3.2). The recombinant plasmid pML1 (mapped by restriction endonuclease digestion) contained the complete gene behind a strong Salmonella typhimurium bacteriophage SP6 promoter. Subsequent deletion of a $1 \mathrm{~kb}$ NruI-SmaI fragment in the plasmid pML2, removed the stretch of intervening nucleotides (URA3 and pBR322 sequences, including a $0.4 \mathrm{~kb}$ sequence upstream of the initation codon of ATP2, as sequenced by Takeda et al., (1985)) between the promoter and coding region of the gene. It is known that the increased length of $5^{\prime}$ untranslated sequence has an adverse effect on translation (H. Bujard, unpublished). The in vitro transcription of RNA enabled radiochemically pure precursor beta subunit polypeptide to be prepared for transport studies using isolated mitochondria.

Plasmid pJ14 was used in the preliminary work on determining the nature and location of sequences required for mitochondrial protein delivery, by in vitro mutagenesis of the cloned ATP2 gene. The ATP2 gene subcloned into plasmid pDS6 as a $3.3 \mathrm{~kb}$ EcoRI fragment, was shortened at the $5^{\prime}$ sequence by limited Bal 31 digestion, to leave 27 nucleotides between the $\mathrm{P} 25(\mathrm{x} / 0)$ promoter and ATG codon of the gene. Figure 3.3 shows the construction of intermediary plasmids and plasmid pGR2O7 (G. A. Reid unpublished). This plasmid was used for nucleotide sequencing, in vitro transcription of RNA and in vitro mutagenesis using gapped heteroduplex DNA molecules. 
Figure 3.4. NUCLEOTIDE SEQUENCE OF ATP2 GENE.

\section{CAGATCTG/TGAGAGAAAACAAAAATAAAAAAAAGA}

\section{BgIII -27}

Ser

1 met val leu pro arg leu tyr thr ala thr arg ala ala phe lys 16 ATG GTT TTG CCA AGA CTA TAT ACT GCT ACA CGT GCT GCT TTT AAA

Dra I

17 ala ala lys gln ser ala pro leu leu ser thr ser trp lys arg 31 GCA GCC AAA CAA TCC GCT CCG CTT CTA TCC ACT TCG TGG AAA AGA

$$
\text { TATC G }
$$

32 cys met ala ser ala ala gln ser thr pro ile thr gly lys val TGT ATG GCC TCA GCT GCT CAA TCT ACT CCA ATC ACA GGT AAA GTT

$$
\text { P v UI I }
$$

The nucleotide sequence shown was confirmed by sequence determination of both strands. The numbers indicate the amino acid residues from the amino-terminal end of the precursor protein of F1B. The restriction sites for BglII, DraI, and PvuII used in gene manipulations of the gene are underlined. The double lines indicate the regions of sequence which differ from the initial published sequence (Takeda et al., 1985) and the small sized lettering the actual base sequence reported different by Takeda et al., (1985) where different from our determination. 


\subsection{DNA SEQUENCING OF ATP2 GENE.}

The DNA sequence of the $5^{\prime}$ untranslated and coding region of the ATP2 gene was determined in both directions by the primer extension dideoxychain termination method (Sanger et al., 1977). The gene originating from plasmid pJ14 was recloned into $\mathrm{M} 13$ vectors $\mathrm{mp} 19$ and $\mathrm{mp} 18$, as a $2.3 \mathrm{~kb}$ EcoRI-SalI fragment and a $0.1 \mathrm{~kb}$ EcoRI-PvuII fragment respectively. The sense and antisense strands of the $5^{\prime}$ region of the ATP2 gene were sequenced using single stranded DNA templates isolated from these M13 recombinants. Differences in nucleotide sequence were noted between our sequence and the published one (Takeda et al., 1985) altering the predicted primary sequence of the protein. In sequencing the antisense strand, severe compressions of the DNA sequence tracks were found in the EcoRI-PruII region of the gene, which made reading of the sequence extremely difficult. However, secondary structures noted as such compression patterns were not observed in the coding strand. The sequence reported by Takeda and coworkers (1985) was determined only from the antisense strand. The observed difference of at least six nucleotides in their sequence affected the amino acid sequence, by a frame shift in the codon reading, which was later restored in the mature sequence (figure 3.4). A corrected sequence has been recently published which is in full agreement with the data reported in this study (Takeda et al., 1986).

3.3. ONE STEP DISRUPTION OF THE ATP2 GENE.

A yeast strain lacking $F 1 \beta$ activity was constructed by the one-step gene disruption method. This would provide a 

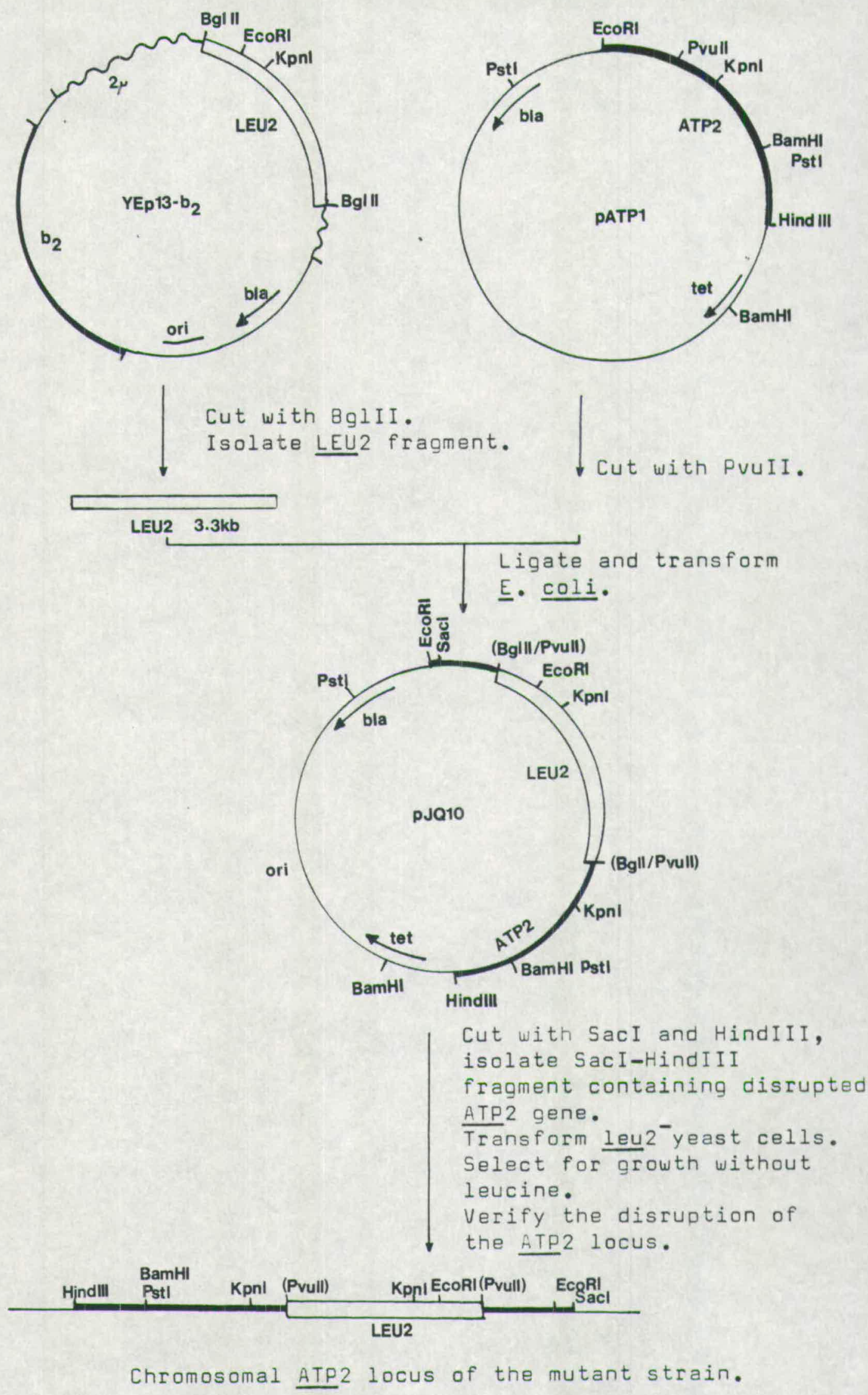
Fiqure 3.6 .

ONE STEP DISRUPTION OF THE ATP2 GENE ON THE YEAST CHROMOSOME: SOUTHERN BLOT ANALYSIS OF GENOMIC DNA.

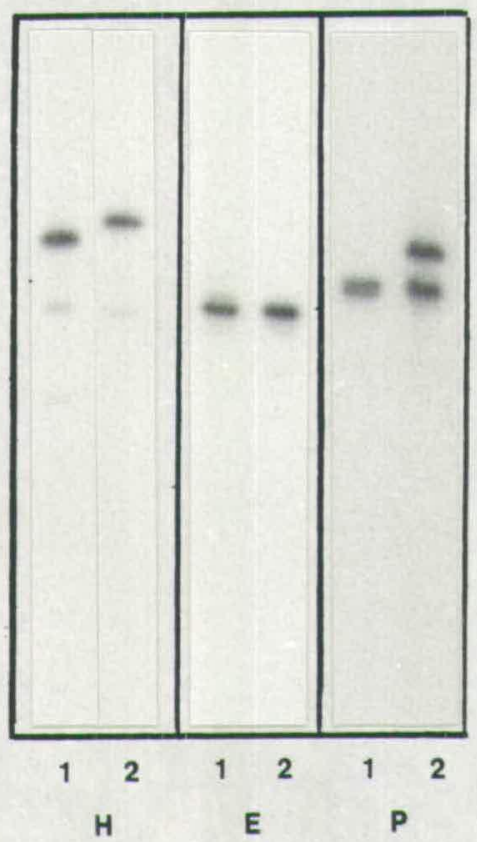

The interrupted ATP2 gene has replaced the wild-type gene on the chromosome.

Genomic DNA was isolated from wild-type yeast SF747-19D and the LEU2 transformant JQ1 according to Materials and Methods. An aliquot of 1 ug DNA was cut with either EcoRI, Hind III, or PstI and the digests were separated on a $0.8 \%$ agarose gel in TBE. The "DNA was denatured, transferred to nitrocellulose filter and fixed by baking $\left(80^{\circ} \mathrm{C}\right)$. Southern blotting: the filter was prehybridised with excess denatured DNA from salmon sperm to block unbound sites on the membrane. DNA sequences coptaining the ATP2 gene were detected by hybridisation using a 2 p labelled probe. The $2.3 \mathrm{~kb}$ probe (EcoRI-SalI) was synthesised from M13 mp19 by second-strand synthesis. The filter was washed and the specific radiolabelled bands were detected by autoradiography.

(1) wild-type SF747-19D; (2) LEU2 transformant JQ1.

(H) HindIII; (E) EcoRI; (P) PstI. 
Fiqure 3.7 .

ONE STEP DISRUPTION OF THE ATP2 GENE ON THE YEAST CHROMOSOME: WESTERN BLOT ANALYSIS OF PROTEIN FROM CELL EXTRACTS.

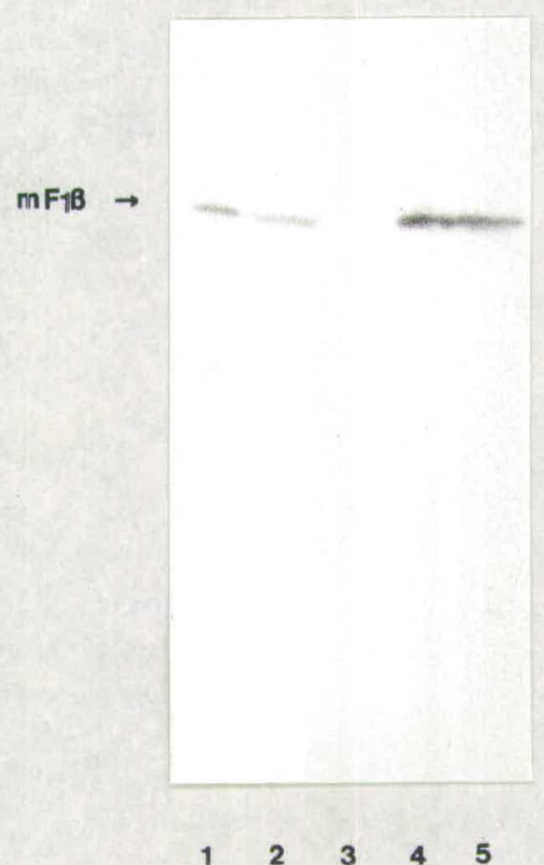

The interrupted ATP2 gene has replaced the wild-type gene on the chromosome.

Wild-type SF747-19D, the LEU2 transformant JQ1 and JQ1 transformed with plasmid pFL1-11-3 were groun from single colony in LYPD to $00600=0.6$. Cells were harvested and protein was extracted by glass beads and TCA according to Materials and Methods. The solubilised protein extracts were loaded onto a SDS-12\% polyacrylamide gel (equal amounts of total protein). After separation, the proteins were transferred to nylon membrane and immunodecorated with antisera against $F 13$ subunit, followed by ${ }^{125}$ I- protein A. The radiolatelled bands correspand -ing to beta subunit were detected by autoradiography. 1. mitochondria from wild-type $0273-10 B$ (marker for F $1 \beta$ ); 2. wild-type SF747-19D; 3. LEU2 transformant JQ1; 4. JQ1 transformed with $\mathrm{PFL} 1-11-3 ; 5$. JQ1 transformed with PMC $4 F 1 \beta$. 
suitable host to study the transport of plasmid-encoded mutant beta precursor polypeptides in the absence of endogenous chromosome-encoded beta subunit. The properties of the mutant polypeptides would otherwise be masked by endogenous protein because of similarity in size and immunological reactivity. The strategy used is described in figure 3.5. The mutant JQ1 thus obtained had become LEU' and contained the LEU2 gene inserted into the ATP2 gene. Chromosomal DNA was analysed by Southern blotting using a $2.3 \mathrm{~kb}$ ATP2 probe made by second strand synthesis from an M13 mp19 recombinant containing the EcoRI-SalI ATP2 fragment, to probe digests with EcoRI, HindIII and PstI. The ATP2 locus in SF747 was found to be replaced by the chimeric LEU2-ATP2 gene, from plasmid pJQ10 (figure 3.6). The plasmid-borne gene was inserted at the PvuII site, corresponding to codon 35 of the beta subunit precursor polypeptide. Its expression would be expected to produce an oligopeptide containing only thirty-five amino acids of the beta subunit precursor, which should not be immunologically detectable. The mutant lacked any protein recognised by antibodies raised against beta subunit protein (figure 3.7 ), and thus was deficient in oxidative phosphorylation. JQ1, as expected, was unable to grow on glycerol, ethanol or lactate as sole carbon source. When beta subunit was expressed, after transformation of JQ1 with pFL1-11-3 ( containing the gene) it complemented the atp2 lesion and restored growth on glycerol.

Another mutant, GR1, was constructed in an analogous manner by inserting a $1.1 \mathrm{~kb} U R A 3$ fragment into the PvuII site of the 
Figure 3,8. EXPRESSION OF BETA SUBUNIT OF YEAST ATP SYNTHASE IN SACCHAROMYCES CEREV ISJAE.

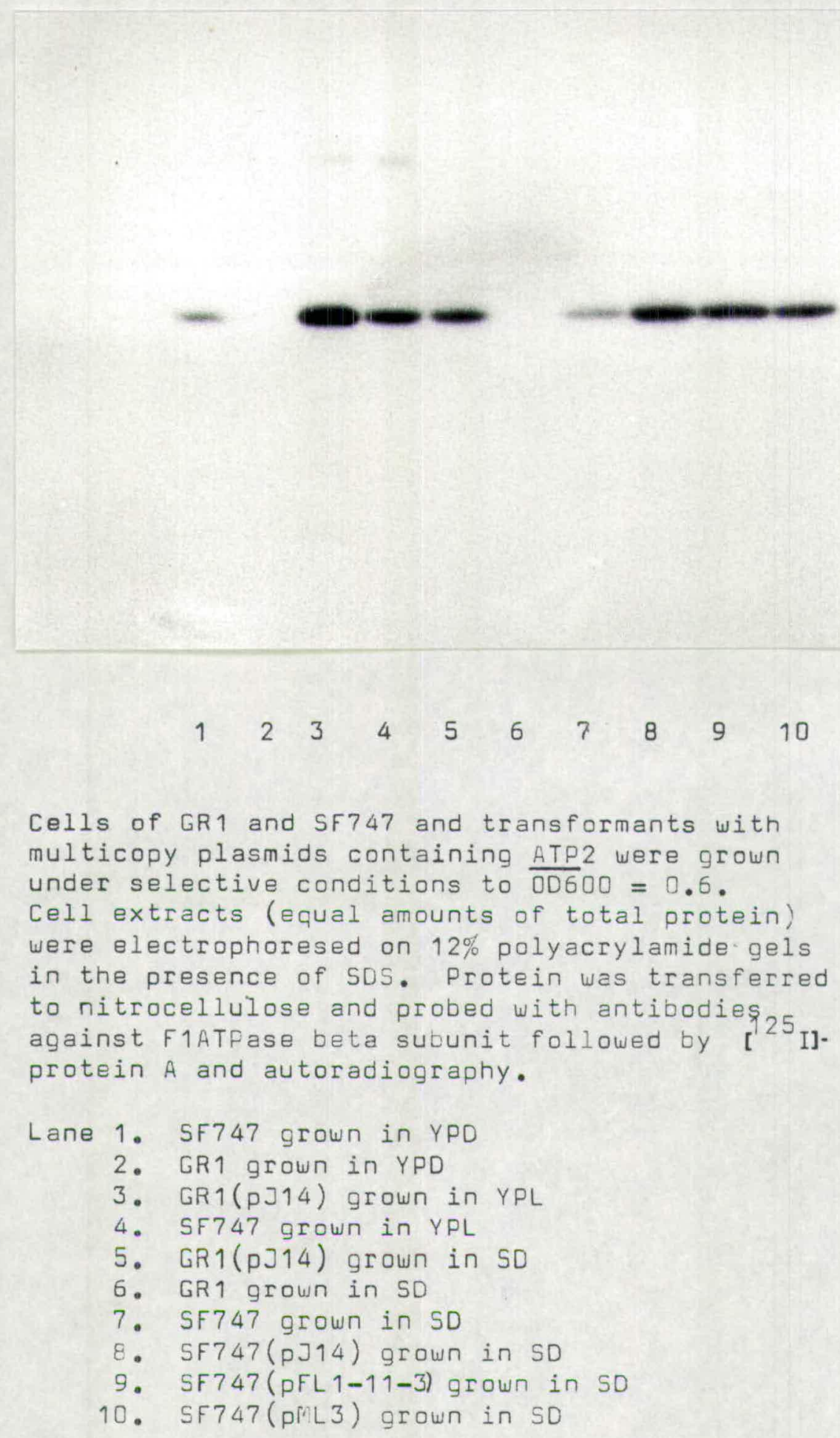


ATP2 gene. The different auxotrophic requirement of JQ1 (histidine and uracil) and GR1 (histidine and leucine) was useful in selecting transformants which contained plasmids carrying the ATP2 gene and the yeast marker genes URA3 and LEU2. The expression of beta subunit of F1-ATPase was investigated in GR1, SF747 and transformants containing the ATP2 gene on multicopy plasmids. Figure 3.8 shows the steady state levels of protein extracted from cells grown to mid logarithmic phase $\left.\left(\mathrm{OD}_{6} 0_{0}\right)_{2}\right)$. The radioactive bands corresponding to beta subunit were cut out of the membrane filter and the incorporation of radioactivity was counted in a gamma counter. A similar sized band from a blank track on the filter was used to determine the background radioactivity. Beta subunit was only detected in GR1 after transformation with pJ14, containing the ATP2 gene. In the same experiment, SF747 transformed with pJ14 and pFL1-11-3 increased the level of protein $3.5-4$ fold above that of the chromosomal copy. However, when the $0.4 \mathrm{~kb}$ sequence upstream of the initiation codon, was removed in the plasmid pFL1-11-3, as in plasmid pML3, the level of expression decreased from 3.5 fold to 2.5 fold. Like many mitochondrial proteins encoded by nuclear genes, beta subunit expression was repressed under growth in glucose. Figure 3.8 shows that the difference observed in SF747 was 2 fold greater when grown in $2 \%$ sodium lactate (YPL) as compared with growth in $2 \%$ glucose (YPD). Thus the $1.6 \mathrm{~kb}$ EcoRI-HindIII fragment cloned in pJ14 and pFL1-11-3 contains the structural gene for the beta subunit of F1-ATPase.

3.4. IN VITRO TRANSCRIPTION-TRANSLATION OF THE ATP2 GENE. 
The SP6 in vitro transcription system (Butler and Chamberlin, 1982) was chosen for the synthesis of RNA encoding the ATP synthase beta subunit. A salient feature of the system is the exclusive initiation at the SP6 promoter by Salmonella typhimurium phage SP6 RNA polymerase, which avoids transcripts being intiated elsewhere in the plasmid (Krieg and Melton, 1984). It was shown that the ATP2 gene could be transcribed efficiently in plasmids pML1 and pML2, as uncapped RNA and translated in either wheat germ lysate (Roberts and Paterson, 1973) or rabbit reticulocyte lysate (Pelham and Jackson, 1976). The apparent requirement of a $5^{\prime}$ terminal cap for RNA stability and translation observed with beta globin message in oocytes (Krieg and Melton, 1984) was not demonstrated. The level of protein produced from RNA capped in the transcription reaction using the cap analog 7mGpppG and SP6 RNA polymerase, was not significantly greater than an identical transcription reaction without the cap analog.

Inefficient synthesis of beta subunit protein in both wheat germ and reticulocyte lysates, and the presence of multiple protein bands associated with wheat germ lysate ( probably from premature termination or from processing activity) limited its use in producing radiochemically pure proteins.

The transcription-translation system based on transcription of genes from a $\mathrm{T}_{5}$ coliphage promoter by $E$. coli RNA polymerase, was used to produce beta subunit (Stueber et al., 1984; Hurt et al., 1984). RNA was capped during transcription using a cap analog $7 \mathrm{mGpppA}$, which is incorporated by $E$. coli RNA polymerase at the site of mRNA initiation. Precursor protein to beta subunit was synthesised in the 
PLASMIDS USED FOR IN VITRD TRANSCRIPTION OF RNA ENCODING BETA SUBUNIT PRECURSOR POLYPEPTIDE.

\section{PGR201}
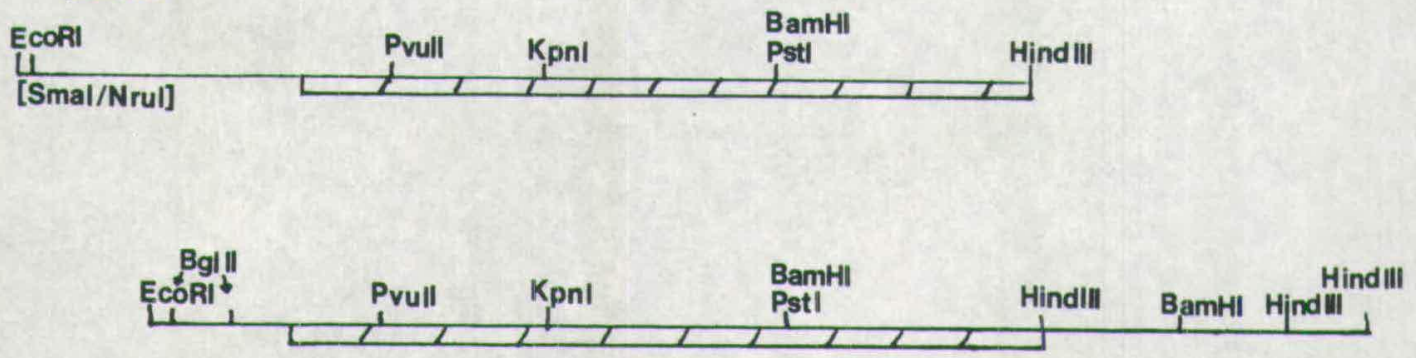

\section{PGR206-89B}

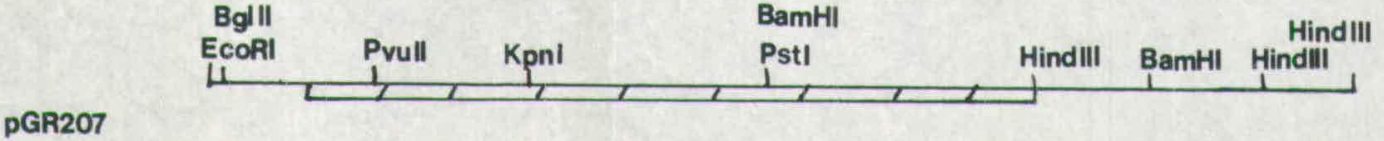

Beta subunit was synthesised in an in vitro transcriptiontranslation system based on the transcription of the ATP2 gene from a $T_{5}$ phage promoter using $\underline{E}$. coli RNA polymerase (Stueber et al., 1984).

A series of PDS6 plasmid derivatives containing the ATP2 gene were constructed to determine the effect of non-coding nucleotide sequences on the translation of beta subunit. The plasmids only differ in the $5^{\prime}$ and $3^{\prime}$ non-coding regions of the gene.

The coding region of ATP2 is represented by the boxed line, and the varying lencths of $5^{\prime}$ and $3^{\prime}$ untranslated sequence by the thin line. 
IN VITRO TRANSCRIPTION OF RNA ENCODING BETA SUBUNIT USING E. COL I RNA POLYMERASE.

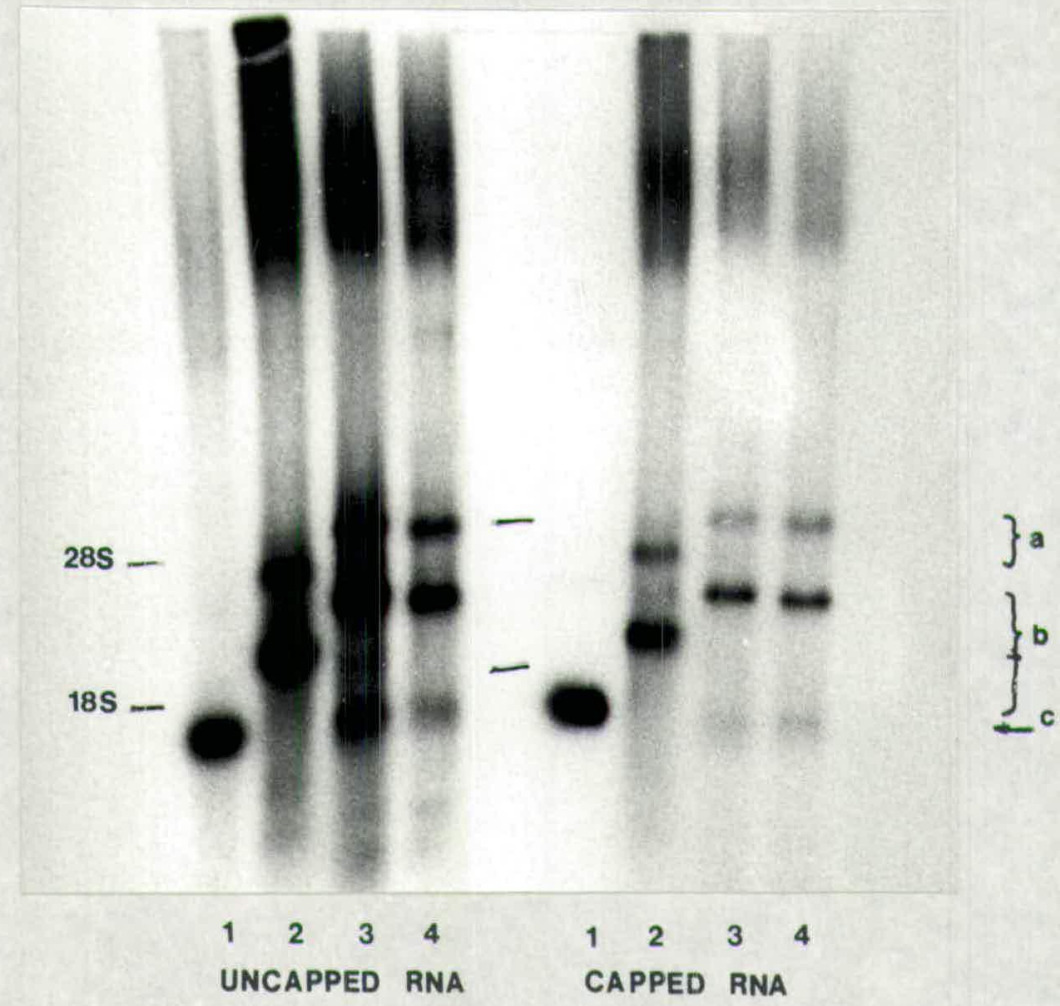

RNA encoding beta subunit was transcribed from the cloned ATP2 gene from the $T_{5}$ coliphage promoter using E. coli RNA polymerase.

Incubation was carried out for $3 \mathrm{~min}$ at $37^{\circ} \mathrm{C}$ in a reaction volume of $10 \mathrm{\mu l}$ containing $20 \mathrm{mPl}$ HEPES $\mathrm{KOH} \mathrm{pH} 7.9 ; 10 \mathrm{~mm}$

Mg. acetate; $200 \mathrm{mM} \mathrm{K}$. acetate; $5 \mathrm{mM}$ DTT; $0.2 \mathrm{mP}$ spermidine; $0.5 \mathrm{mP}$ each of GTP, CTP and UTP; $1 \mu \mathrm{Ci}[32 \mathrm{P}] \mathrm{GTP}, 13 \mathrm{U}$ RNasin; 6.5 ug plasmid DNA and $1 \mathrm{U}$ of E. coli RNA polymerase. Cap analog $7 \mathrm{mG} p p$ A was added to $0.1 \mathrm{~mm}$ for capping of RNA during the transcription reaction. After $3 \mathrm{~min}, 0.5 \mu \mathrm{l}$ of $20 \mathrm{~mm}$ ATP was added and incubated for a further $10 \mathrm{~min}$ before chilling on ice to stop the reaction.

$2 \mu l$ of the transcription mixture $(0.2 \mu \mathrm{C} i)$ was separated on a denaturing gel ( $1 \%$ agarose $2.2 M$ formaldehyde gel) as according to Maniatis et al., $(1982)$. The gel was stained with acridine orange to detect the RNA markers, and afterwards dried and exposed to $X-r a y$ film to detect the radiolabelled RNA bands of the in vitro transcription assay.

1. OHFR (pDS7); 2. F1 $(p G R 201) ; 3$. F $1 \beta(p G R 206-898)$ 4. F $1 \beta$ (pGR207). The letters $a, b, c$ represent bi-cistronic RNA derived from read-through into the cat gene; monocistronic RNA of the cloned gene and RNA product of the bla gene respectively. RNA markers: $15 \mu g$ of total yeast RNA (28S and 185 IRNA). 


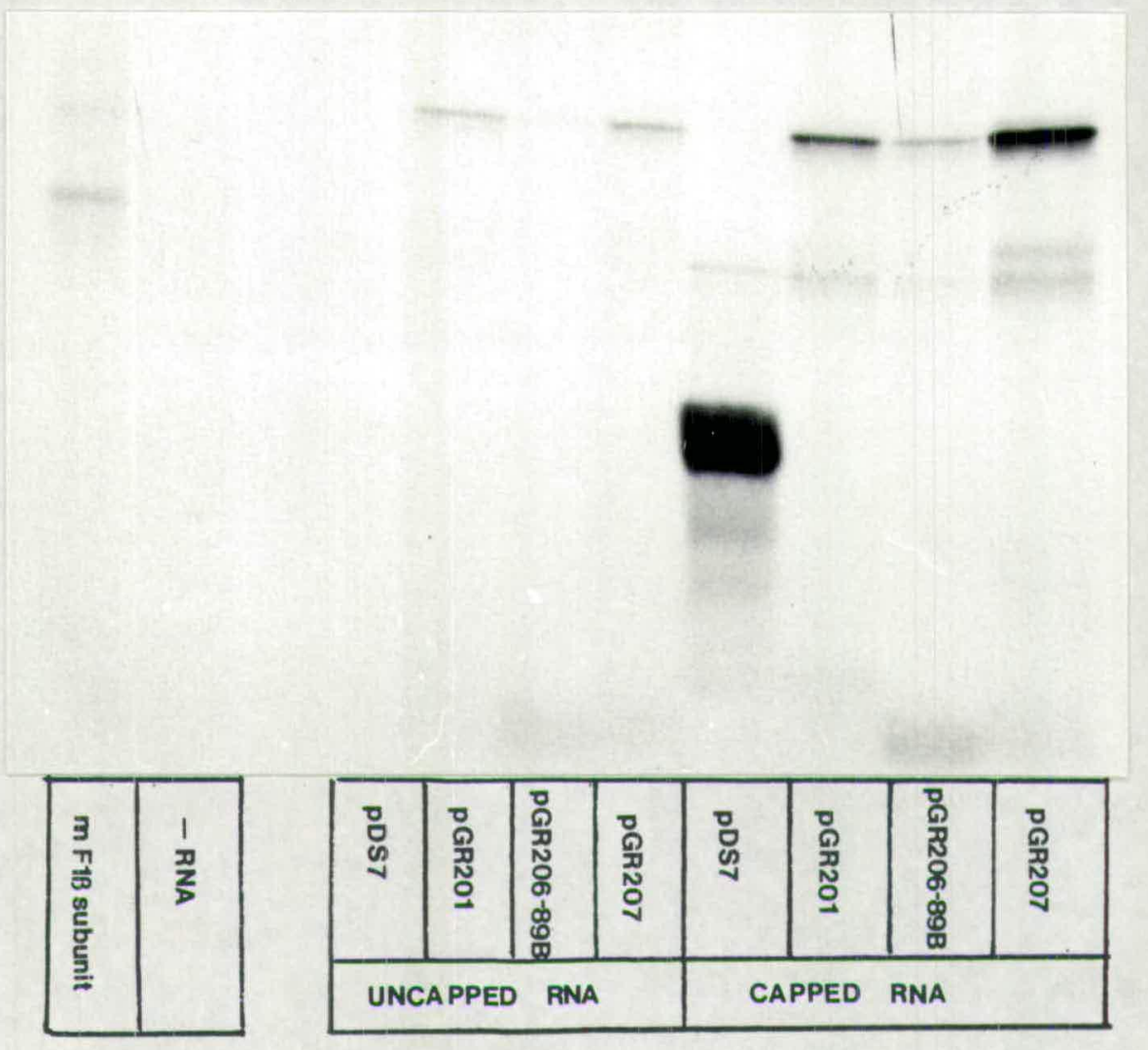

RNA encoding beta subunit was translated in vitro in wheat germ lysate as according to Roberts and paterson (1983). Incubation was carried out at $25^{\circ} \mathrm{C}$ for $60 \mathrm{~min}$ in a reaction volume of $25 \mu 1$. The reaction assay contained $2 \mu 1$ transcription mixture, 0.02M HEPES-KOH pH 7.6, $0.05 \mathrm{M} \mathrm{K}$. acetate, $1.25 \mathrm{~mm}$ Mg. acetate, $0.25 \mathrm{mM}$ spermidine, $1 \mathrm{mM}$ ATP, $0.05 \mathrm{mP}$ GTP, $8 \mathrm{mM}$ Creatine Phosphate, $0.025 \mathrm{~mm}$ of 19 amino acids minus gethionine, $2 \mathrm{mM}$ DTT, $0.1 \mathrm{mg} / \mathrm{ml}$ creatine phosphate kinase, 5 uCi ${ }^{35} \mathrm{~S}-$ methionine and $5 \mu l$ wheat germ lysate. RNasin was included $(13 \mathrm{U})$ to preserve RNA substrate.

After translation the radiolabelled polypeptides were analysed by SDS-PAGE. $12 \mu l$ of the translation mixture was ran out on a SDS-12; polyacrylamide gel. The radiolabelled protein bands were detected by fluorography. 
presence of $\left[\begin{array}{ll}35 & \mathrm{~S}\end{array}\right]$ methionine in a rabbit reticulocyte lysate. Reticulocyte lysate was used in preference to wheat germ lysate as the presence of a cytosolic factor in the reticulocyte lysate was demonstrated to facilitate transport of beta subunit of F1-ATPase into isolated mitochondria (Ohta and Schatz, 1984). In addition, it lacks an unspecific processing activity found in wheat germ lysate which cleaves precursor polypeptides to a size similar to mature proteins, although they are not imported (S.M. Gasser and C. J. Leaver, unpublished).

In order to determine the effect of non-coding nucleotide sequences on the translation of beta subunit, a series of plasmids described in figure 3.9 , were constructed which differed in the $5^{\prime}$ and $3^{\prime}$ regions of the ATP2 gene. In vitro transcription using $E$. coli RNA polymerase resulted in three RNA species: one corresponding to the cloned gene, a contaminant due to the bla gene and a bicistronic mRNA from transcriptional read-through at the terminator ' $t_{0}$ ' into the cat gene (figure 3.10). The latter confers chloramphenicol resistence in vivo (Stueber et al., 1984). It was demonstrated that translation of F1 $\beta$ subunit was improved approximately five fold when the 5 , intervening DNA between the phage promoter and ATG initation codon of the ATP2 gene was reduced to 30 nucleotides, (as seen in pGR207). However, there was no significant effect on translation through capping the beta subunit message, in striking contrast with translation of DHFR mRNA transcribed from pDS7. In the latter, the $5^{\prime}$ terminal cap was essential for translation. The efficiency with which the DHFR RNA was translated was found to be about a hundred times greater than capped message of the beta subunit (figure 3.11 ). 
CHAPTER 4.

GENE FUSION STUDIES ON THE IMPORT

OF

BETA SUBUNIT INTO MITOCHONDRIA

IN VITRO AND IN VIVO. 
4. GENE FUSION STUDIES ON THE IMPORT OF BETA SUBUNIT INTO MITOCHONDRIA IN VITRO AND IN VIVO.

4.1. IN VITRO TRANSCRIPTION-TRANSLATION OF THE CHIMERIC ATP2-DHFR GENES.

In the preliminary in vitro transcription-translation experiments radiolabelled precursor to $F 1 \beta$ subunit could not be prepared consistently as a single polypeptide species of high specific radioactivity (see Chapter 3.4). Gene fusion experiments were used as an alternative approach to study transport of beta subunit into isolated yeast mitochondria. Recent studies using fusion proteins between the presequence of either subunit IV of yeast cytochrome c oxidase (Hurt et al., 1984, 1985a,b) or human ornithine transcarbamylase (Horwich et al., 1985) and DHFR have demonstrated that the addition of a mitochondrial presequence may be sufficient for directing the attached cytosolic protein to the mitochondrion. DHFR was shown to be an 'ideal' passenger protein, as it lacks any structural features which may interfere with translocation of the protein (van Steeg et al., 1986). Thus similar deletion and gene fusion experiments were carried out in order to determine the location of targeting information within the beta subunit presequence for transport in vitro and in vivo.

The amino terminal 15 or 35 amino acids of yeast F1及 were fused in front of intact DHFR (1-187), normally a cytosolic protein. Also an in-frame deletion in the F1/ $\beta_{35}-\mathrm{DHFR}$ construct was made between codons 2 and 15 . The in-frame fusion junctions were determined by DNA sequencing of double stranded plasmid DNA 
DHFR

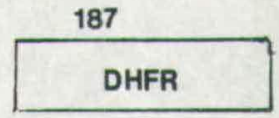

F1ß precursor

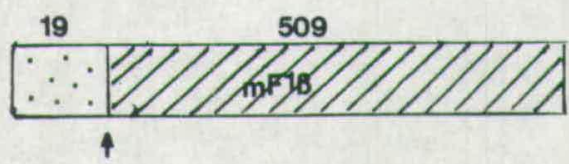

F $1 \beta \overline{15}$ DHFR
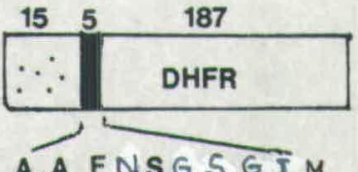

131415 I II III IV V VI 1

F $1 \beta_{35}$ DHFR

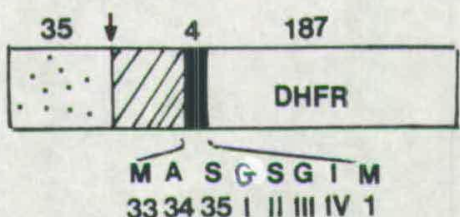

$F 1 \beta-16-35 R$

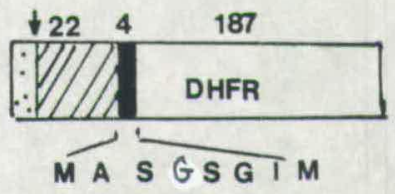

333435 I II III IV 1

Gene constructions. Boxes denote amino acid sequences, Arabic numbers on top of each box the total number of amino acids, and Roman numerals amino acids introduced by gene fusion. DHFR, dihydrofolate reductase from mouse; F $1 \beta$ precursor, precursor to beta subunit of ATP synthasecomprising of a 19 amino acid presequence (dotted box) and 509 amino acid protein (slashed box): $F 13-{ }_{5}$ DHFR fusion protein containing the N-terminal 15 amino acid residues of pF $1 \beta$ (dotted box), five residues introduced by gene fusion (shaded box) and the entire sequence of DHFR. In the fusion junction arabic numerals preceding the Roman numerals denote C-terminal residues of the presequence. F $1 \beta_{\overline{3}}$ DHFR fusion protein containing the first 35 residues of $F$ p $1 \beta$ (dotted box and slashed box), four residues introduced by gene fusion (shaded box) and the DHFR protein. F $1 \beta_{\text {. }}$ HFR contains amino acids $16-35$ of $F 1 \beta$. Arrows indicate sites cleaved by matrix protease. 
and restriction endonuclease analysis (see figure 4.1). The fused genes were cloned in plasmid pDS7 (Stueber et al., 1984) and transcribed with $E$. coli RNA polymerase. The RNAs produced were translated in a reticulocyte lysate system, to give single bands of high specific radioactivity which could be used for studying import into isolated yeast mitochondria.

\subsection{IN VITRO IMPORT OF BETA SUBUNIT-DHFR HYBRID PROTEINS INTO YEAST} MITOCHONDRIA.

Gene fusions were used to determine the length of beta subunit presequence required to direct DHFR, a cytosolic protein, to mitochondria in vitro. Figure 4.2 depicts a typical result of an in vitro import experiment. The cloned gene of the protein (DHFR or fusion protein) was transcribed into capped RNA and translated in the presence of $\left[{ }^{35} \mathrm{~S}\right]$ methionine. When the translation products were separated by PAGE, DHFR or the F1 $\beta$ subunit-DHFR precursor was the only labelled polypeptide detected. When labelled DHFR was incubated with isolated mitochondria in the presence of ATP as an energy source, it was found almost totally in the supernatant fraction and was resistant to exogenous proteinase $\mathrm{K}$. The protease-resistant nature of DHFR protein may reflect the tight tertiary structure the polypeptide assumes after synthesis (Schatz, 1987). Part of the F1 $\beta_{15}-$ DHFR precursor was associated with the mitochondria and was inaccessible to externally added protease, in contrast to the cytosolic precursor (where the presequence was degraded but not the DHFR protein). This inaccessibility of the mitochondriallyassociated protein was overcome by adding the detergent Triton X-100. The imported precursor polypeptide was, 
Figure 4.2. IN UITRO TRANSPORT OF BETA SUBUNIT-DHFR HYBRID PROTEINS INTO YEAST MITOCHONDRIA.

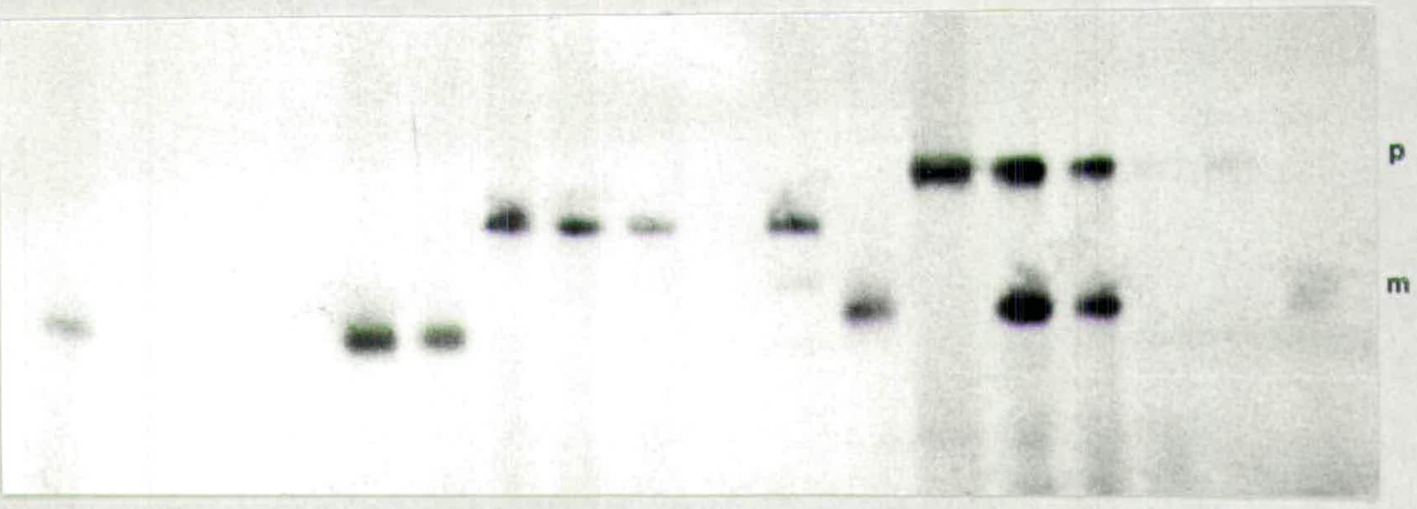

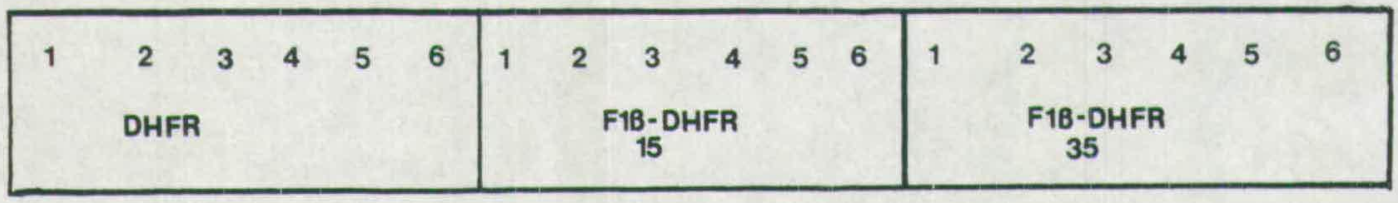

DHFR and beta subunit-DHFR hybrid proteins (F $1 R_{15}$ DHFR, and $F 1 \beta$ DHFR) were synthesised in vitro in the presence of $35_{5}$ methionine and incubated with isolated and energised yeast mitochondria. After $30 \mathrm{~min}$ at $28^{\circ} \mathrm{C}$, mitochondria were reisolated and analysed by SDS $-12 \%$ polyacrylamide gel electrophoresis and fluorography. Lanes 1. translation product; 2 . mitochondria in absence of proteinase $K$ (import assay); 3. mitochondria, proteinase K; 4. mitochondria, proteinase $K$ plus Triton $X-100 ; 5$. supernatant in absence of proteinase $K$; 6 . supernatant, proteinase $K$. (p) precursor form, (m) mature protein. Western blotting with antiserum against $F 1 \beta$ after transfer of proteins to nylon membrane, indicated any cross contażmination of fractions, proteinase $K$ digestion and integrity of mitochondria (data not shown) 
Table 4.1. EFFECT OF POSITIVE CHARGE WITHIN MITOCHONDRIAL PRESEQUENCE ON TRANSPORT OF HYBRID PROTEINS INTO MITOCHONDRIA.

\begin{tabular}{|l|l|cc|}
\hline Hybrid protein & Basic residues present & Import & Processing \\
\hline F1 $\beta_{15}$ DHFR & Arg5 Arg12 & & + \\
F1 $\beta_{16}$ - 35 DHFR & Lys16 Lys19 Lys30 Arg31 & + & + \\
F1 3 $_{35}$ DHFR & Arg5 Arg12 Lys16 Lys19 Lys30 & + & + \\
\hline
\end{tabular}

Differing lengths of beta subunit presequence were fused to DHFR (a cytosolic protein). The precursor proteins were synthesised in vitro in the presence of [ $\left.{ }^{35} \mathrm{~S}\right]$ methionine and incubated with isolated mitochondria. The fate of the radiolabelled proteins was followed by protease digestion after the import assay, gel electrophoresis and fluorography. The efficiency of transport was monitored qualitatively in the amount of precursor protein which was associated with the mitochondrial fraction and supernatant fraction. Sequences required for protein maturation were determined by the presence of mature protein after transport. 
as expected, not processed to the mature form by the matrix endoprotease, since the fusion did not include the cleavage site Lys $_{19}-\mathrm{Gln}_{2} 0$ of the beta subunit (Vassarotti et al., 1987a). A fusion with the first 35 amino acids of beta subunit was readily transported (95\%) and inaccessible to exogenous protease. The precursor was partially matured; both precursor and mature forms were protected against protease digestion in the absence of detergent, indicating that the protein had been imported.

These results suggested that the amino terminal 15 amino acids of F1 3 are sufficient to direct DHFR (a cytosolic protein) to the mitochondrion, and thus constitute a targeting sequence. Transport was enhanced when the length of the presquence included the amino terminus of the mature protein. Recent analysis of a number of mitochondrial proteins including the beta subunit of ATP synthase predicted a strong tendency to form amphiphilic helices (von Heijne, 1986) which may mediate transport across the mitochondrial membrane via interaction with the bilayer (Roise et al., 1986). The amphiphilic helix (as shown in figure 4.3 ), has a cluster of basic residues arranged on a face opposite to hydrophobic and non polar amino acid residues. In this context, one interpretation of the observations made with the beta subunit-DHFR fusions, was that the efficiency with which beta subunit was imported was dependent on the length of amphiphilic helices and number of basic residues within the presequence. In these fusions, the number of basic residues and length of the presequence was increased (table 4.1).

However, at first sight the prediction does not readily explain the observed transport of the F1/35-DHFR fusion 
THE FORMATION OF AMPHIPHILIC HELICES WITHIN THE PRESEQUENCE OF BETA SUBUNIT PRECURSOR POLYPEPTIDE.

The mitochondrial presequence of beta subunit has a predominantly basic nature, and is enriched for hydroxyl-containing residues (serine and threonine) as well as leucine. There are no acidic amino acids and few valine residues. The presequence is predicted to form an amphiphilic helix which may facilitate transport of the attached protein across the mitochondrial membranes (von Heijne, 1986).
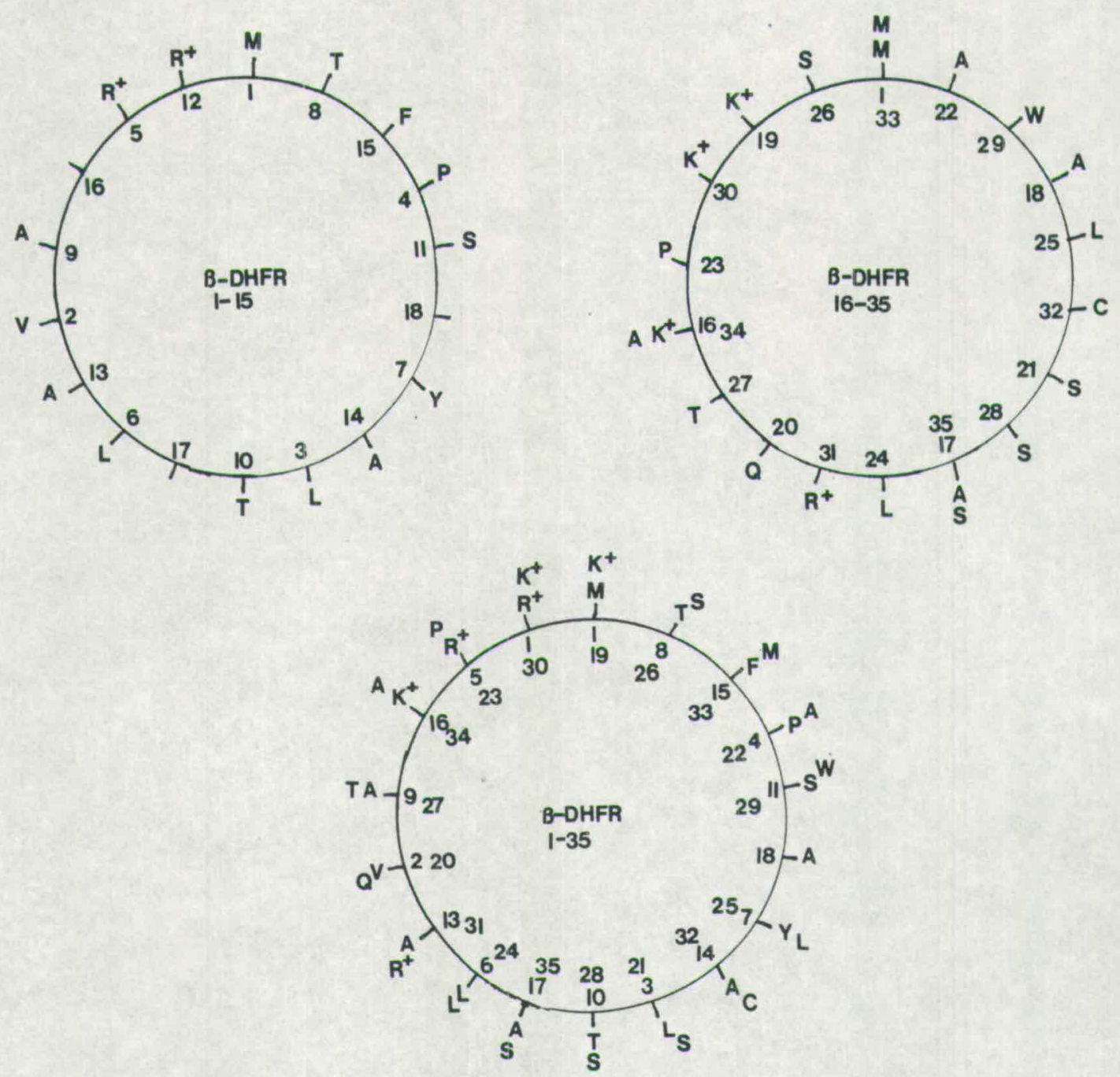

Residues $1-15$ of beta subunit presequence are sufficient to direct an attached cytosolic protein DHFR to the mitochondrion. Transport efficiency is improved with the longer fusions containing either the first 35 residues or residues $16-35$ of beta subunit precursor. This suggests that targeting information may reside within the precursor protein as two independent helices which may act cooperatively in transport. The potential to form amphiphilic helices in the beta subunit-CHFR fusion proteins which may function as targeting signals, is shown as a helical wheel projection (where the amino acid residues are plotted at 100 degrees with respect to each other). The diagrams represent an end-on view of the helix; the distribution of basic residues on one face of the helix and nonpolar and hydrophobic residues on the other face gives the helix its amphiphilic properties (von Heijne, 1986). 


\section{Figure 4.4. IN VITRO TRANSPORT OF HYBRID PROTEINS INTO YEAST MITOCHONDRIA.}

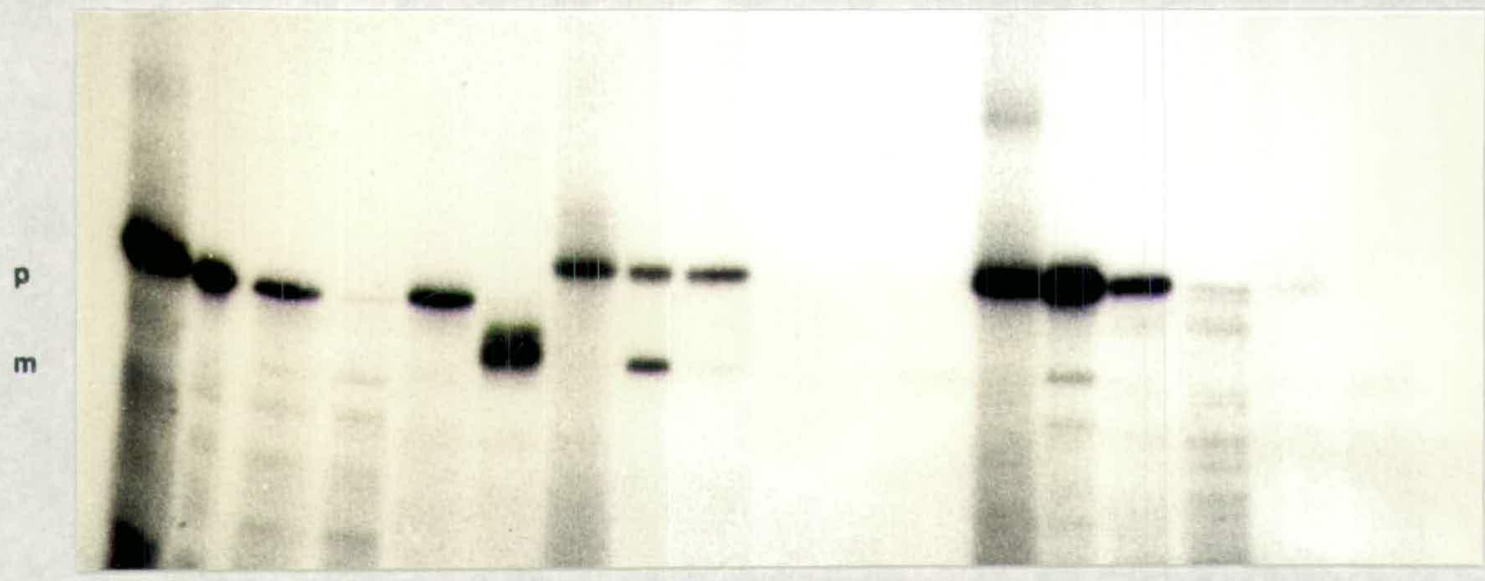

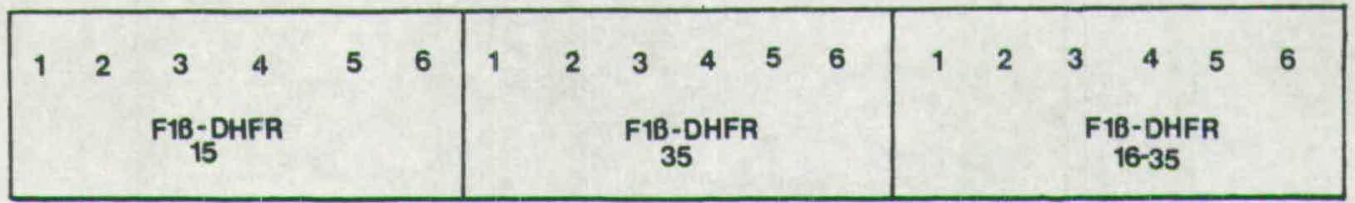

Beta-subunit fusion proteins ( $F 1 F D H F R, F 1 P$. DHFR and F1BDHFR) were synthesised in vitro in the presence of ${ }^{5} \mathrm{~s}$ methionine and incubated with isolated mitochondria in the presence of ATP. After $30 \mathrm{~min}$ at $28^{\circ} \mathrm{C}$, mitochondria were reisolated and analysed by SDS $-12 \%$ polyacrylamide gel electrophoresis and fluorography.

Lanes 1. translation product; 2. mitochondria; 3 . mitochondria plus proteinase $k ; 4$. mitochondria, proteinase $k$, plus Triton $X-100 ; 5$. supernatant; 6 . supernatant, proteinase $k$. (p) precursor form, $(m)$ mature form of fusion protein. Western blotting with antiserum against cytochrome b 2 after transfer of proteins to nylon membrane, indicated integrity of mitochondria, proteinase $k$ digestion and cross contamination of fractions (data not shown). 
containing an internal deletion between codons 2 and 15 , (F1 $\left.\beta_{16-35}-\mathrm{DHFR}\right)$, compared to $\mathrm{F} 1 \beta_{15}-\mathrm{DHFR}$ and F1 $\beta_{35}-\mathrm{DHFR}$. Fig 4.4 showed that part of the F1 $\beta_{15}$-DHFR precursor was targeted and internally located in the mitochondrion, whilst a large amount remained in the supernatant. The F1 $\beta_{16-35}-D H F R$ fusion was imported at an efficiency comparable to $\mathrm{F} 1 \beta_{35}-\mathrm{DHFR}$, with little remaining in the supernatant. However, there was only limited processing by the matrix located protease, as seen after long exposure of the autoradiograph. This suggests that sequences upstream of the cleavage site are required for the correct folded secondary structure to be recognised by the endoprotease. The presequence of F1 $\beta$ subunit possesses two targeting domains located between amino acids 1 and 15 and 16 and 35 which can act independently in fusion proteins. The first signal has weak targeting function, and is enhanced by the presence of the second signal, which suggests that the mature protein may play an important part in mitochondrial protein delivery. However, the mature protein is not transported into the mitochondrion in vivo (Vassarotti et al., 1987a).

Interestingly, both targeting signals have the potential to form an amphiphilic helix, as depicted in figure 4.3. The helices differ in the net positive charge and length. These observations are consistent with recently published work on the beta subunit (Vassarotti et al., 1987a). A series of nested deletions from codon 36 towards the amino terminus which progressively reduced the amphipathic sequence (residues 1-36) of the beta precursor was shown to decrease the efficiency in mitochondrial targeting in vivo. The results from such studies suggest that the targeting signal is localised in the amino 
terminus of the precursor polypeptide; (the length of the basic amphiphilic structure being critical for import). The minimum length of sequence which constitutes a targeting signal is 10-15 amino acids (containing 1-2 basic residues in a short amphiphilic helix). An increase in the basic amphipathic stretch of sequence possibly as two independent helices to include 4-6 basic residues, greatly enhances delivery.

\subsection{TARGETING OF BETA SUBUNIT-DHFR HYBRID PROTEINS IN VIVO. \\ 4.3.1. ATP2-DHFR gene fusions.}

In vitro studies using beta subunit-DHFR hybrid proteins showed that the amino terminal 15 amino acids of $F 1 \beta$ subunit can direct mitochondrial import of DHFR. The efficiency of transport was improved when the hybrid precursor polypeptides contained either the first 35 amino acids or amino acid residues 16 to 35 of the presequence. The hybrid proteins were examined in vivo in order to determine whether the deleted presequences could direct transport of an attached protein to the mitochondria. The ideal passenger would have been the mature beta subunit protein, in which transport may be directly assayed by gene complementation of the atp2 mutation after transformation of JQ1 with the plasmid-encoded altered ATP2 genes. These deletions within the ATP2 gene are currently being made.

In order to determine whether the fusion proteins are targeted to the mitochondrion in vivo, the chimeric genes were constructed in a multicopy plasmid, pVT1O2-A. Each gene fusion was cloned between the yeast $A D H 1$ promoter and terminator sequences for expression in yeast, and was identical to the 
SUBCELLULAR FRACTIONATION STUDIES: BETA SUBUNIT-DHFR HYBRID PROTEINS ARE IMPORTED INTO THE MITOCHONDRION IN VIVO.

HK

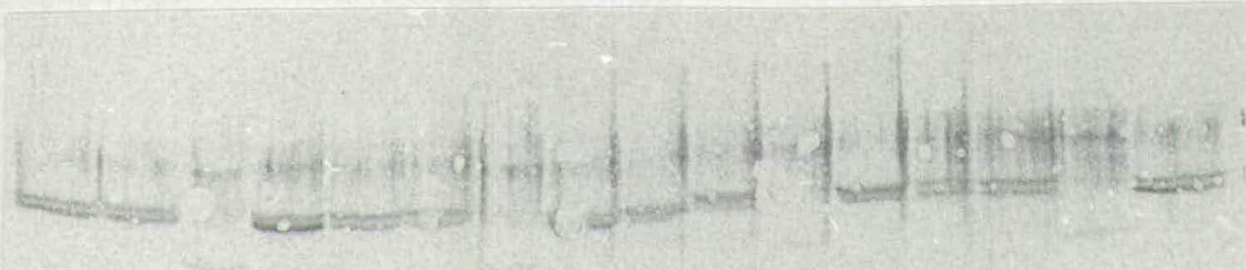

\begin{tabular}{|c|c|c|c|c|c|c|c|c|c|c|c|c|c|c|c|}
\hline$\frac{0}{9}$ & $\bar{g}$ & $\underline{\underline{3}}$ & $£$ & $\frac{n}{7}$ & gू & $\underline{\underline{z}}$ & $£$ & $\frac{9}{7}$ & है & $\stackrel{3}{\underline{3}}$ & $£$ & $\frac{9}{7}$ & हु & $\underline{\equiv}$ & $\stackrel{2}{2}$ \\
\hline \multicolumn{4}{|c|}{ EMY 12} & \multicolumn{4}{|c|}{ MLY 10} & \multicolumn{4}{|c|}{ MLY 13} & \multicolumn{4}{|c|}{ SF747 } \\
\hline
\end{tabular}

FIB

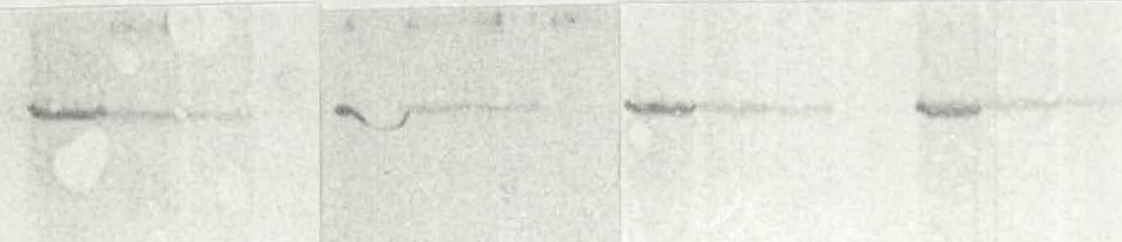

B-DHFR

\begin{tabular}{|c|c|c|c|c|c|c|c|c|c|c|c|c|c|c|c|}
\hline$\frac{\infty}{\frac{0}{7}}$ & б & $\underline{\exists}$ & $\stackrel{2}{1}$ & $\frac{n}{3}$ & శ్ & $\stackrel{\Xi}{\underline{z}}$ & $\underline{\Omega}$ & $\frac{89}{9}$ & 总 & $\underline{3}$ & 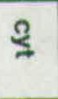 & $\frac{48}{y}$ & J & $\underline{\underline{\underline{B}}}$ & $£$ \\
\hline \multicolumn{4}{|c|}{ EMY 12} & \multicolumn{4}{|c|}{ MLY 10} & \multicolumn{4}{|c|}{ MLY I3 } & \multicolumn{4}{|c|}{ SF747 } \\
\hline
\end{tabular}

SF747 and transformed cells containing plasmid-encoded beta subunit-DHFR fusion proteins (EMY $12=F \beta_{35}$ PHFR, MLY $10=F 1 \beta$ DHFR, MLY13 = F1ßDHFR), were grown in liquid SD minimal medium containing $2 \%$ glucose and were fractionated into spheroplasts (sph), homogenate (hom), mitochondria (mit), post-mitochondrial supernatant (cyt) as described in Materials and Methods. Equal amounts of protein as estimated by PACE blue staining were analysed by SDS-10\% polyacrylamide. gel electrophoresis and immune blotting using antisera against beta subunit ( $F \mathcal{B}$ ) as an internal mitochondrial marker and yeast hexokinase (HK, as a cytosolic marker). Beta subunit-DHFR fusion proteins were detected with antibodies raised against mouse DHFR. 
fusions described in Chapter 4.1.

The hybrid beta subunit-DHFR proteins were expressed in the yeast strain SF747, after transformation. The levels of protein expressed for each hybrid was determined by western blot analysis of cell extracts of strains grown in $2 \%$ glucose (SD medium) to an $\mathrm{OD}_{600}=1$. Figure 4.5 shows that protein was detected by antisera raised against DHFR.

\subsubsection{Beta subunit-DHFR hybrid proteins are targeted to mitochondria.}

The subcellular location of the various beta subunit-DHFR hybrid proteins was determined by isolating mitochondrial and post-mitochondrial supernatant fractions from transformants MLY10, MLY13 and EMY12. Western blot analysis using antibodies against mouse DHFR, and cytosolic yeast hexokinase and the beta subunit of yeast ATP synthase, a mitochondrial matrix protein, demonstrated the mitochondrial location of hybrid proteins. No endogenous yeast protein was shown to cross-react with the antisera in untransformed SF747.

The steady state levels of F1 $\beta_{16-35} \mathrm{DHFR}$ protein in MLY1O was less than the hybrid proteins F1 $\beta_{35}$ DHFR in EMY12 and F1 $\beta_{15}$ DHFR in MLY13, which presented difficulties in its detection. In two separate yeast isolates the presence of antigen could not be clearly seen on the immunodecorated nylon filter. No proteolytic maturation was observed for the precursor to $\mathrm{F} 1 \beta_{15} \mathrm{DHFR}$, whilst $\mathrm{F} 1 \beta_{35} \mathrm{DHFR}$ was cleaved to the mature form (figure 4.5). In vitro translation products (DHFR, F1 $\beta_{15}$ DHFR and $F 1 \beta_{35}$ DHFR) were included for identification of the in vivo products (data not shown). The results were consistent with the in vitro experiments described in Chapter 
4.2. The hybrid proteins were imported in vitro and in vivo, but proteolytic maturation was only seen in the fusion containing the entire beta subunit presequence. Overexposure of the autoradiograph from in vitro transport experiments did detect a limited amount of processing in F1 $\beta_{16-35}$ DHFR.

The inability to detect protein in MLY10 corresponding to F1 $\beta_{16-35}$ DHFR could not be explained. Restriction analysis of the plamsid pML10 showed that the fusion gene was subcloned in pVT102A, and was not rearranged during amplification in $E$. coli. The limited time available to complete the in vivo experiments did not allow characterisation of the transformants after selection on minimal medium plates for the plasmid encoded URA3 marker genes. This would require recovery of the plasmid and retransformation back into yeast. Expression of the hybrid proteins should be studied at the transcription level by Northern analysis of RNA transcripts, or at the translation level by pulse label experiments. The kinetics of transport may be studied by following proteolytic maturation of $\left[3^{5} \mathrm{~S}\right]$ radiolabelled precursor polypeptides during a subsequent chase with unlabelled methionine.

These experiments demonstrate that the presequence of beta subunit was sufficient to direct DHFR, a cytosolic protein, to the mitochondrion in vivo. In addition, the presequence contains a matrix targeting signal within the first 15 amino acids, and a domain overlapping the proteolytic cleavage site between residues 16 and 35 , which is required for maturation of the precursor polypeptide. This latter sequence can also direct targeting to the mitochondria. 
CHAPTER 5.

ANALYSIS OF THE STRUCTURAL REQUIREMENTS

OF A TARGETING SIGNAL WITHIN

THE BETA SUBUNIT PRECURSOR PROTEIN. 
5. ANALYSIS OF THE STRUCTURAL REQUIREMENTS OF A TARGETIG SIGNAL WITHIN THE BETA SUBUNIT PRECURSOR PROTETN.

5.1. In vitro mutagenesis of the cloned ATP2 gene.

In an attempt to identify single amino acid residues or sequences in the beta subunit presequence that are required for transport, a series of single and multiple amino acid changes were made within the first 15 residues. Gene fusion studies have previously shown that this was the minimum length of presequence required to constitute a targeting signal in the precursor polypeptide (Chapter 4). Point mutations were generated in a single stranded region of the cloned ATP2 gene, by bisulphite mutagenesis using a gapped heteroduplex DNA molecule (Kalderon et al., 1982).

The strategy for mutagenesis is outlined in figure 5.1. The mutagenised region of the ATP2 gene was a 67 base pair loop created in the heteroduplex molecule between the BglII and DraI sites of the ATP2 gene, and included 27 nucleotides of 5 ' upstream sequence and codons 1-15 (see figure 3.4). The $\mathrm{C} \rightarrow \mathrm{T}$ transitions, which result from deamination of cytosine bases, were maintained by direct transformation into an ung - strain of E. coli, BD1528, which lacks uracil N-glycosylase. This enzyme specifically recognises and removes uracil bases in the DNA by hydrolysing the glycosidic bond, the first step in repair of uracil-containing DNA (Lindahl, 1982). Transformants were picked and screened by restriction endonuclease digestion using DraI to distinguish between cells carrying the deletion plasmid pGR209 from those with the full length gene in pGR2O7 (figure 
STRATEGY FOR IN VITRO MUTAGENESIS OF CLONED ATP2 GENE ENCODING THE FIRST 15 CODONS OF PRECURSOR POLYPEPTIDE TO BETA SUBUNIT.

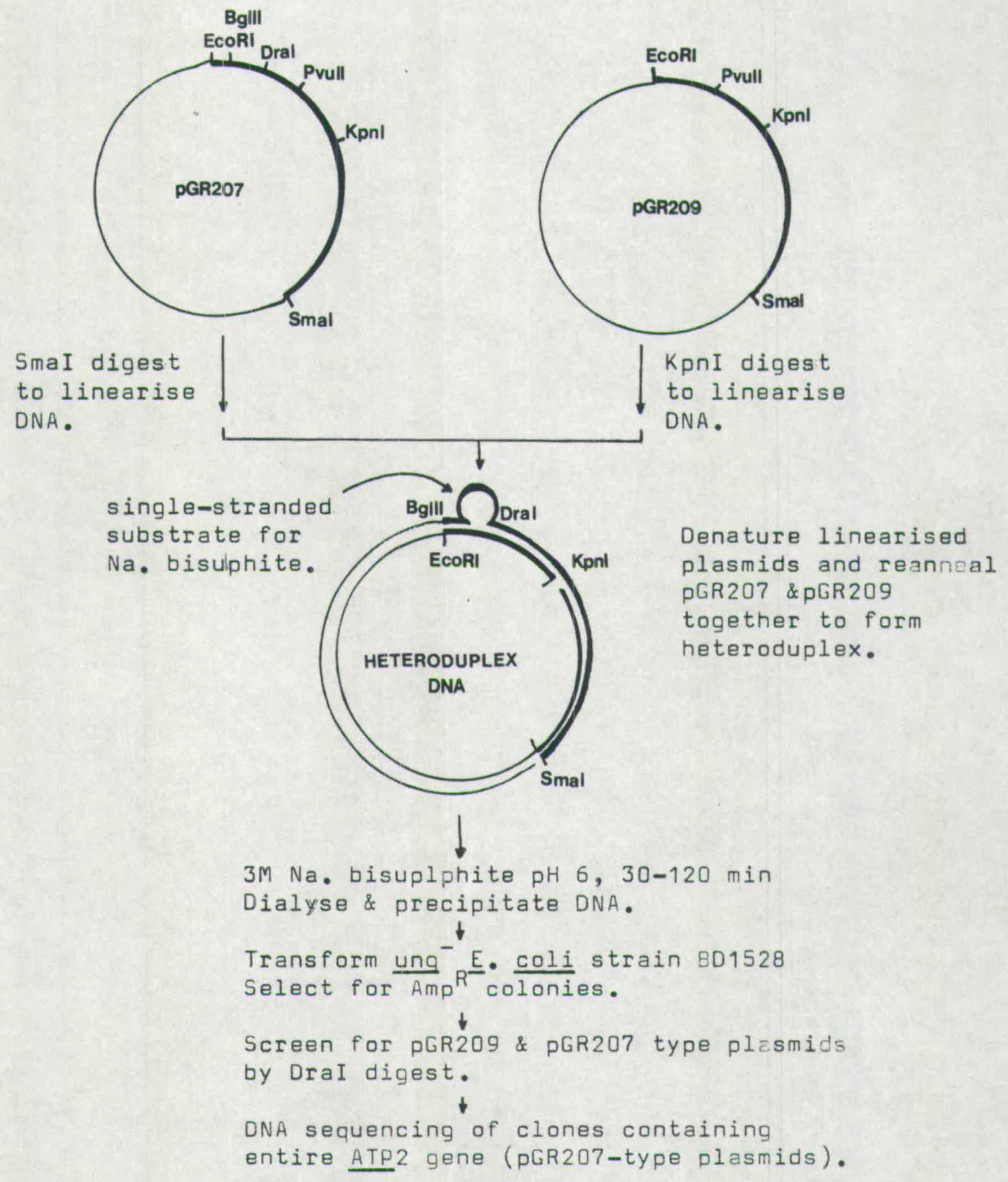


Fiqure 5.2 .

ANALYSIS OF E. COLI TRANSFORMANTS AFTER TRANSFORMATION WITH MUTAGENISED ATP2 DNA: RESTRICTION ENDONUCLEASE DIGESTION WITH DRAI.

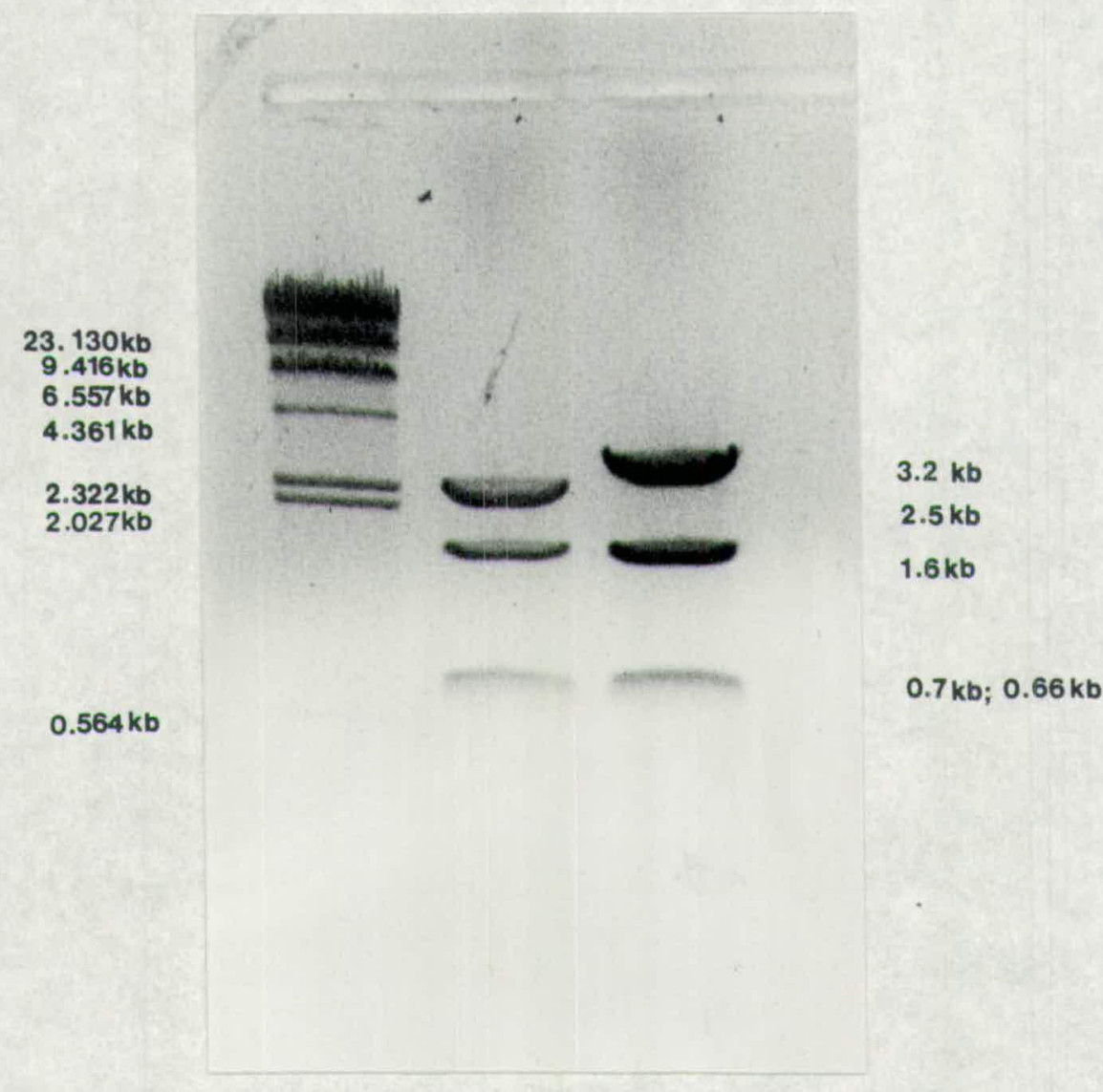

入. Hind III pGR207 PGR209

Plasmid pGR207 contains six restriction sites for DraI, which give the following sized fragments: $0.3 \mathrm{~kb}, 0.66 \mathrm{~kb}, 0.7 \mathrm{~kb}$, $1.6 \mathrm{~kb}$ and $2.5 \mathrm{~kb}$. The removal of the 67 nucleotides between the BglII and DraI sites in the ATP2 gene (as in pGR209) leads to the loss of a DraI site and a fragment. The restriction pattern which is observed are fragments of $3.2 \mathrm{~kb}, 1.6 \mathrm{~kb}, 0.7 \mathrm{~kb}$ and $0.3 \mathrm{~kb}$. Transformants with plasmids containing the entire ATP2 gene (ie PGR207) were further analysed by nucleotide sequencing of plasmid DNA. 


\section{Fiqure 5.3 .}

ANALYSIS OF E. COLI TRAISFORMANTS AFTER TRANSFORMATION WITH MUTAGENISED ATP2 DNA: DIDEOXYCHAIN TERM INATION SEQUENC ING OF 5 ' SEQUENCE OF ATP2 GENE.
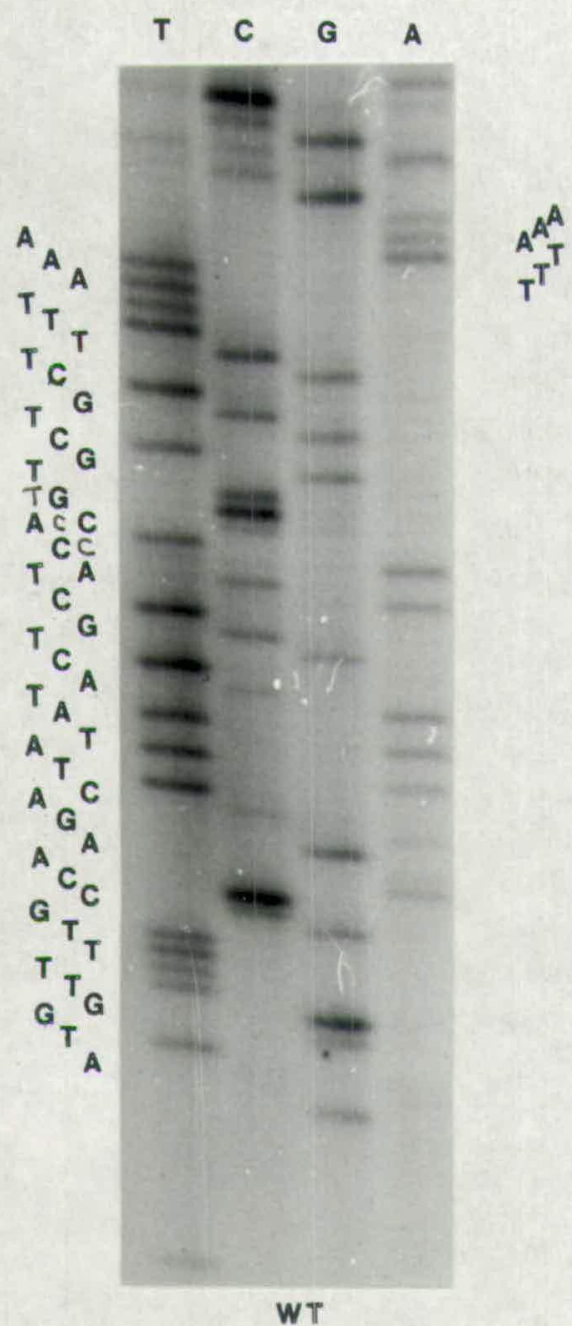

T C G A T C, G A

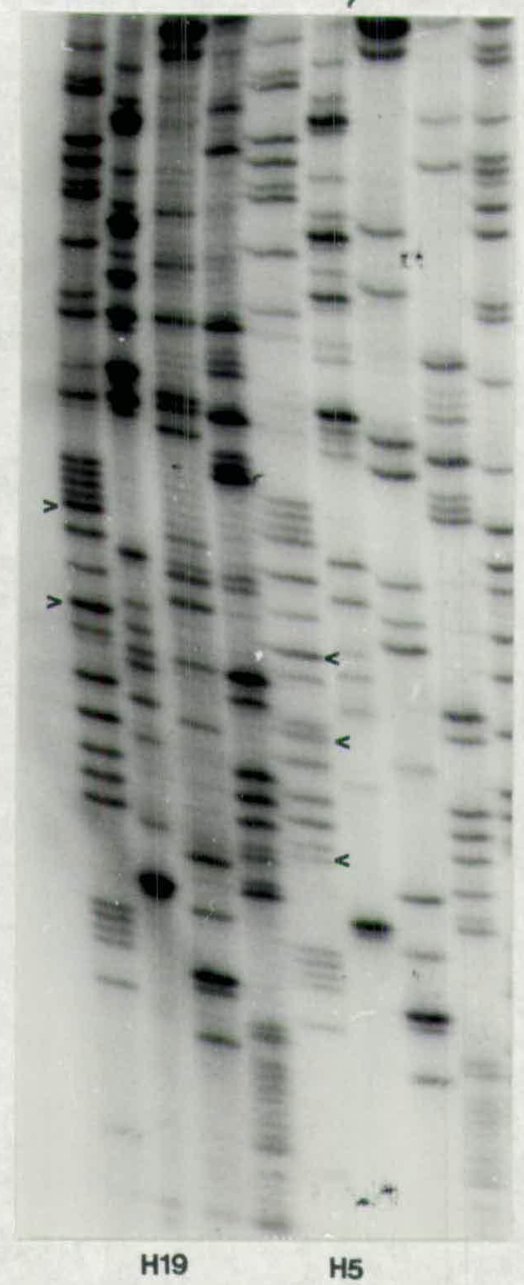

Bisulphite mutagenesis causes $C \rightarrow T$ transitions which are detectable in the DNA sequence by nucleotide sequencing. Plasmid was prepared by CsCl/ethidium bromide buoyant density gradients or alkaline lysis method, and sequenced according to wallace et al., (1981). The oligonucleotide primer POS1 was used which hybridises close to the insertion site of the ATP 2 gene in pDS6, and allows the nucleotide sequence to be read from the EcoRI site down through the gene. The arrows indicate $C \rightarrow T$ transitions in the mutated DNA. The restriction site for DraI is shown on the sequence TTTAAA. Lanes TCGA are the four base reactions in the dideoxychain termination sequencing of the DNA. 
Table 5.1. RESULTS OF BISUPLHITE MUTAGENESIS.

\begin{tabular}{|c|c|c|c|c|c|c|}
\hline $\begin{array}{l}\text { Mutagenesis } \\
\text { time (min) }\end{array}$ & $\begin{array}{l}\text { Number of } \\
\text { transformants }\end{array}$ & $\begin{array}{l}\text { Number of } \\
\text { transformants } \\
\text { screened }\end{array}$ & \multicolumn{4}{|c|}{$\begin{array}{l}\text { Plasmid population } \\
\text { pGR2O7 pGR209 mixed Others } \\
\text { popul }\end{array}$} \\
\hline 30 & 130 & 86 & 36 & 27 & 18 & \\
\hline 60 & 58 & 37 & 6 & 16 & 10 & \\
\hline 120 & 239 & 108 & 43 & 39 & 9 & 8 \\
\hline 240 & 69 & 10 & 3 & 5 & 1 & 1 \\
\hline
\end{tabular}

Bisulphite mutagenesis was performed as described in Materials and Methods. The mutated region was $67 \mathrm{bp}$ in length. 241 transformants were screened by restriction digest with DraI, to classify into the above populations. The category "Other" refers to plasmids which contain a restriction pattern different from plasmids pGR207 and pGR209, where there were extra DraI sites generated by the mutagenesis in the plasmid. 
Table 5.3. DNA AND AMINO ACID SEQUENCES OF THE BISULPHITE MUTANTS CHARACTERISED.

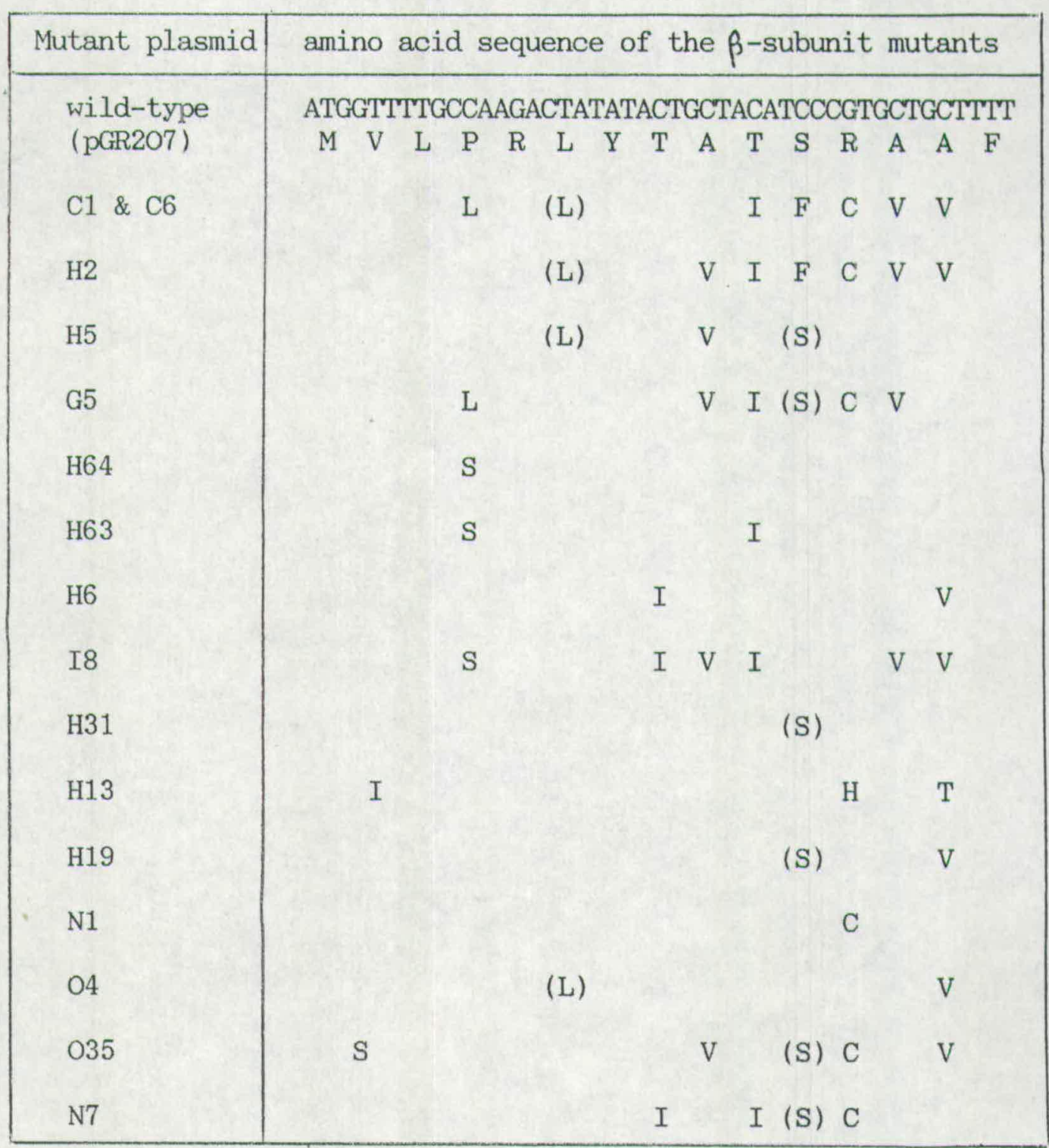

There were 19 cytosine bases on the two strands in the 45 nucleotide long mutagenised region of the ATP2 encoding the first 15 residues of the beta subunit protein. The single letter codes for amino acid changes from the wild-type ATP2 sequence is given above. Brackets represent silent mutations. 
5.2). Plasmid pGR2O7 contains six restriction sites for DraI which give the following sized fragments $-0.3 \mathrm{~kb}, 0.66 \mathrm{~kb}, 0.7 \mathrm{~kb}$, $1.6 \mathrm{~kb}$ and $2.5 \mathrm{~kb}$. The removal of 67 nucleotides between the BglII and DraI sites in the ATP2 gene (as in pGR2O9) leads to the loss of a DraI site and a fragment. The restriction pattern which is observed showed fragments of $3.2 \mathrm{~kb}, 1.6 \mathrm{~kb}, 0.7 \mathrm{~kb}$ and $0.3 \mathrm{~kb}$. The DNA which was mutagenised contained a mixed population of homoduplex linear molecules (pGR2O7 and pGR2O9) and heteroduplex DNA substrate. The heteroduplex molecules were produced by annealing together both plasmids pGR2O7 and pGR2O9 which had been cut with SmaI and KpnI respectively. The mixture was directly transformed into $E$. coli without further purification of the heteroduplex DNA, as the transformation efficency of linearised molecules is considerably less than open circular molecules such as heteroduplex molecules. Transformants were found to contain a single plasmid species, either pGR2O9 or pGR207, although mixed plasmid populations were noted. Spurious mutations were detected by the digestion analysis, in which extra DraI sites were created in the plasmid. The mutagenesis results are summarised in Table 5.1. A set of 38 plasmids containing the entire gene, as defined by restriction digestion was chosen for further screening by dideoxynucleotide sequencing of the plasmid DNA (figure 5.3). The set included one clone with a silent mutation (H31), five with single amino acid changes, five with 2-3 changes and seven with 4 or more substitutions. One mutant (H28) which contained several changes, was devoid of the ATG initiation codon, through the base substitution of ATG to ATA. The remainder were unmutagenised in the $5^{\prime}$ sequence. In 
Table 5.2. NUCLEOTIDE SEQUENCE OF THE $5^{\prime}$ NON-CODING REGION OF THE ATP2 GENE IN THE BISUPHITE MUTANTS CHARACTERISED.

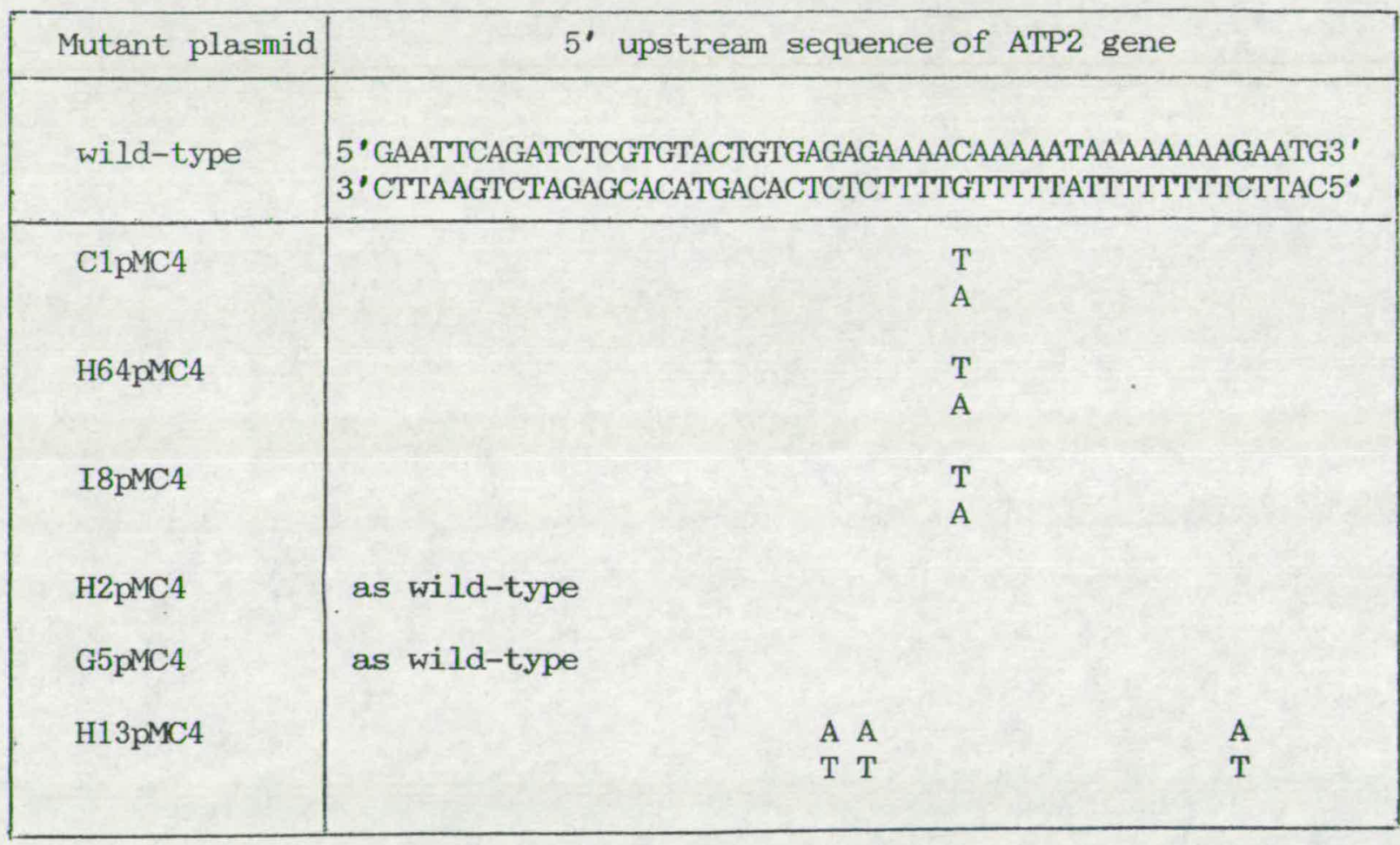

There were 10 cytosine bases on the two strands in the 27 nucleotide long mutagenised $5^{\prime}$ non-coding region of the ATP2 gene. 
the mutants listed in Table 5.2 , three contained a single $C \rightarrow T$ transition in the $27 \mathrm{bp}$ upstream sequence of the gene $(\mathrm{C} 1$, H64, I8), and in a single example, H13, there were three changes. The base transitions and the resulting amino acid substitutions were dependent on the DNA strand that was mutated. In all cases except H13, the changes were on the coding strand. It is difficult to explain this observation, although the possible formation of hair pin structures in the single-stranded DNA template may interfere with the action of the bisulphite mutagen.

Spurious mutations in the mature coding region which arose undetected by restriction mapping, were removed by subcloning the mutagenised region (including codons 1-35) into a clean ATP2 background in the yeast centromere plasmid pMC4-F1ß. The plasmids containing the mutant sequence were designated by a letter-number code, as for example C1pMC4, compared to the unmutagenised beta subunit - pMC4-F1ß. The pMC4-F1 $\beta$ plasmids were used to study transport of precursor protein in-vivo. For in-vitro studies, the first 35 codons of the mutagenised DNA were fused in front of DHFR cloned in pDS7.

5.2. IN VITRO TRANSPORT OF MUTANT BETA SUBUNIT PRECURSOR POLYPEPTIDES INTO MITOCHONDRIA.

Mutant targeting sequences in F1 $\beta$ subunit were tested for transport in vitro in a fusion protein containing the first 35 amino acids of F1B subunit attached to DHFR. Radiolabelled fusion protein was synthesised in vitro in the presence of $\left[{ }^{35} \mathrm{~S}\right]$ methionine and incubated with isolated mitochondria in the 
IN VITRO TRANSPORT OF MUTANT BETA SUBUNIT-DHFR PRECURSOR POLYPEPTIDES INTO MITOCHONDRIA.

Mutents which behaved as wild type in transport and processing.

FLUOROGRAM:

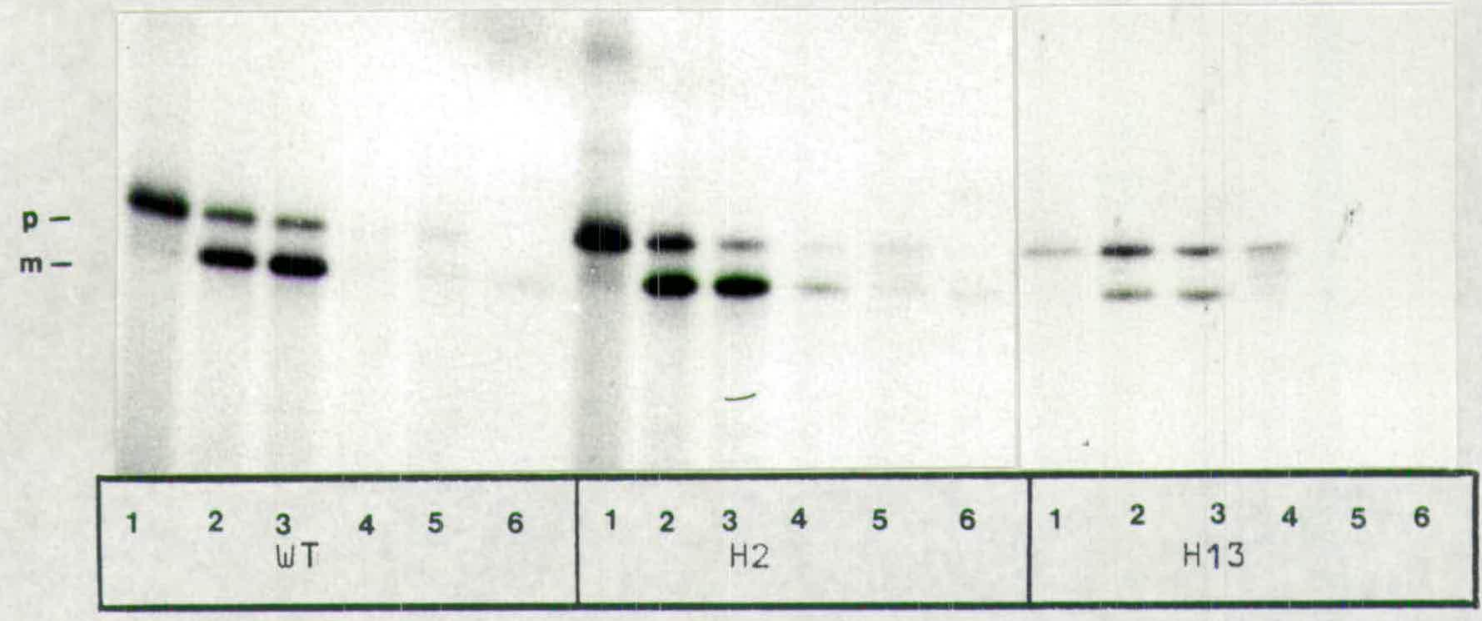

WESTERN BLOT:

F1B

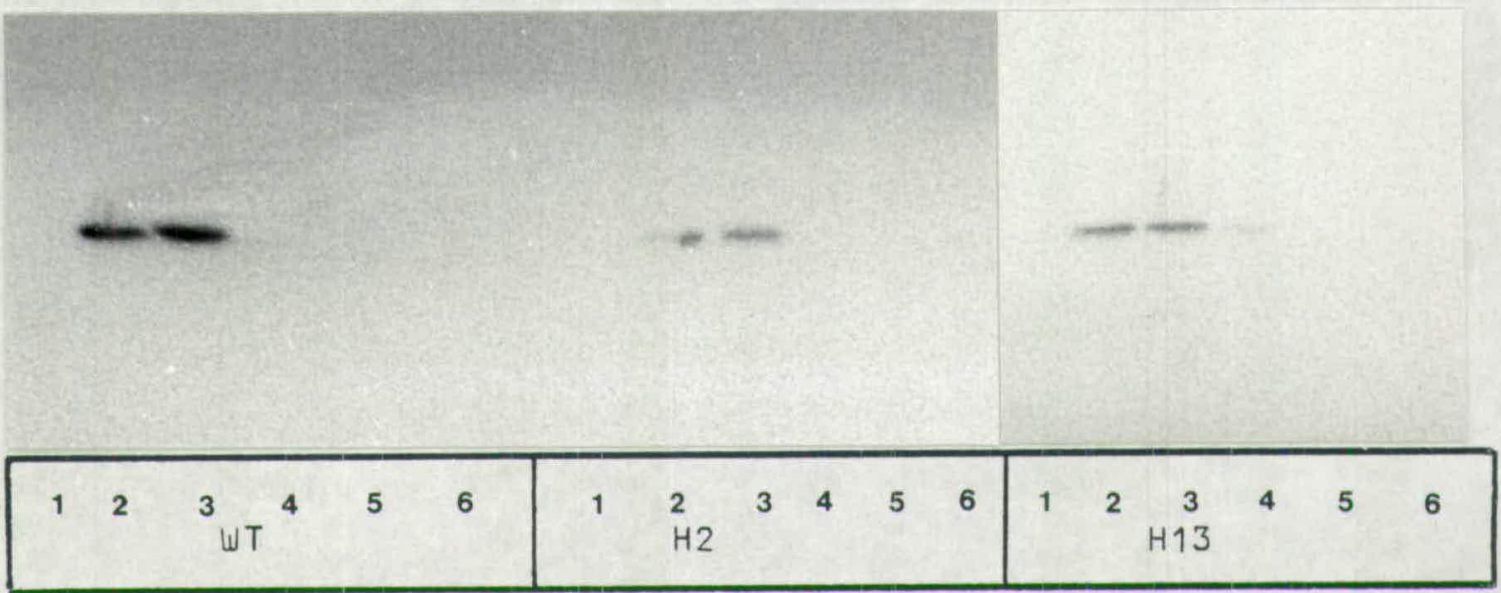

Mutant precursor polypeptides were compared as with wild type in transport into isolated yeast mitochondria and maturation. The following were found to be similar to wild type: H5, H6, H13, H2, $\mathrm{N} 1, \mathrm{035}, \mathrm{H} 19$, and $\mathrm{H64}$.

Fusion proteins ( $F 1 \beta_{3}$ DHFR) were synthesised in vitro in the presence of ${ }^{35}$ methionine and incubated with isolated yeast mitochondria in the presence of ATF. After $30 \mathrm{~min}$ at $28^{\circ} \mathrm{C}$, mitochondria were reisolated and analysed by SDS-12\% polyacrylamide gel electrophoresis and fluorography. Lanes 1. translation product; 2. plus mitochondria 3. mitochondria plus proteinase $k ; 4$. mitochondria, proteinase $k$ plus Triton $X-100 ; 5$. supernatant; 6. supernatant, proteinase $k$. $(p)$ and $(m)$ represent precursor and mature forms of hybrid protein. western blots of proteins transferred onto nylon membrane using antibodies to $F 1 \beta$ subunit indicated the integrity of the mitochondria, cross contamination of fractions and proteinase $K$ and Triton $x-100$ treatments. 
IN VITRO TRANSPORT OF MUTANT BETA SUBUNIT-DHFR PRECURSOR POLYPEPTIDES INTO MITOCHONDRIA.

Mutants which were altered in transport and processing.

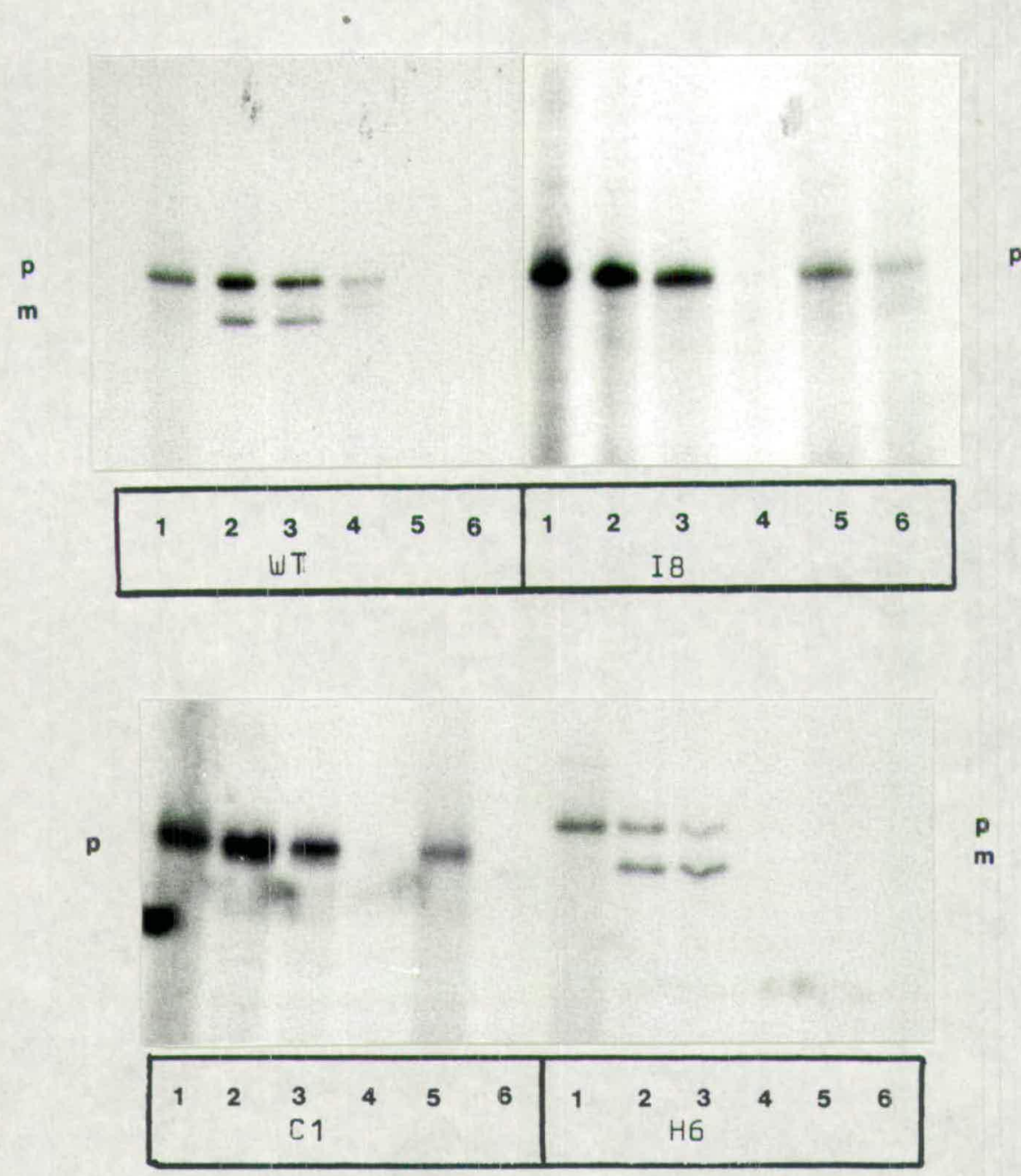

Mutants I8, G5 and C1 were shown to be transported with less efficiency than wild type, the mitochondrial precursor was accessible to proteinase $K$ digestion. Maturation of the precursor polyptide was not observed.

Mutant and wild type fusion Bfoteins ( $\mathbb{P}_{\text {Ss }}$ OHFR) were synthesised in vitro in the presence of ${ }^{5} 5$ methionine and incubated with isolated yeast mitochondria in the presence of ATP. After 30 min at $28^{\circ} \mathrm{C}$, mitochondria were reisolated and analysed by SDS$12 \%$ polyacrylamide gel electrophoresis and fluorography. Lanes 1. translation product; 2. plus mitochondria; 3. mitochondria, proteinase $\mathrm{K} ; 4$. mitochondria, proteinase $K$ plus Triton $\mathrm{X}-100$; 5. supernatant; 6 . supernatant plus proteinase $k$. $(p)$ precursor form of fusion protein, (m) mature fusion protein.

western blots of proteins transferred onto nylon membrane using antibodies to $F 1 \beta$ subunit indicated the integrity of the mitochondria, cross contanination of fractions and proteinase $k$ and Triton $X-100$ treaments.

H6 was used as WT equivalent for processing and transport. Data for mutant ES is not shown. 
presence of ATP as an energy source. Transport and proteolytic maturation in twelve mutants was compared with that observed with unmutagenised beta subunit attached to DHFR. The results in figure 5.4 show that the majority were indistinguishable from wild type (WT) beta precursor in transport, and only three mutants (I8, C1, G5) were found to be transported with less efficiency and not processed (figure 5.5). Mutant H28, which lacked the initation methionine codon was, as expected, not translated as no detectable protein was observed. One can interpret from these observations as shown in Table 5.3, that the position and multiplicity of amino acid changes in the sequence may have an effect on delivery to the matrix by altering the secondary structure of the presequence. Multiple changes such as the substitution of threonine and serine by isoleucine and phenylalanine, alanine by valine, or arginine by cysteine found in clusters near to the processing site for maturation of beta subunit (mutants I8, C1, G5) may either increase the hydrophobic nature of a small region or alternatively form a less compact and amphiphilic helix as a result from the bulky side groups. The subsequent effect on mitochondrial delivery appears to be on membrane translocation or proteolytic maturation of the mutant precursor polypeptide. However, where the amino acid changes are spatially distributed throughout the first 15 residues of the presequence (as in mutants $\mathrm{N} 7$ and 035 ) the alteration of secondary structure may be negligible since transport was not affected. In support of this prediction, the kinetics of transport were examined in the mutants $\mathrm{H} 13$ and I8 as compared with wild type beta subunit-DHFR hybrid protein. Time course experiments showed $\mathrm{H} 13$ and beta 
Wild type

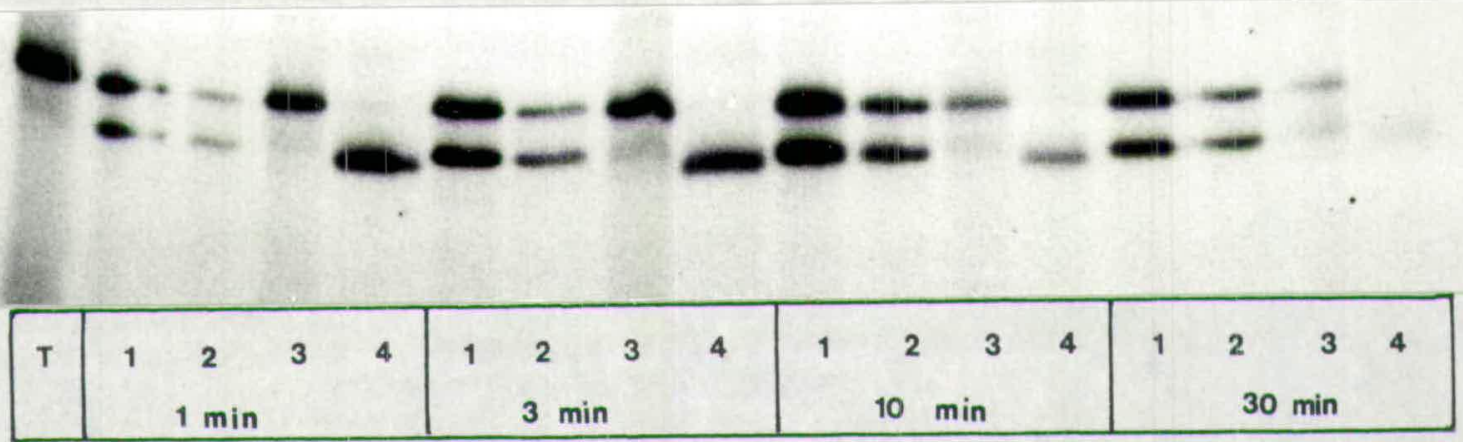

H13

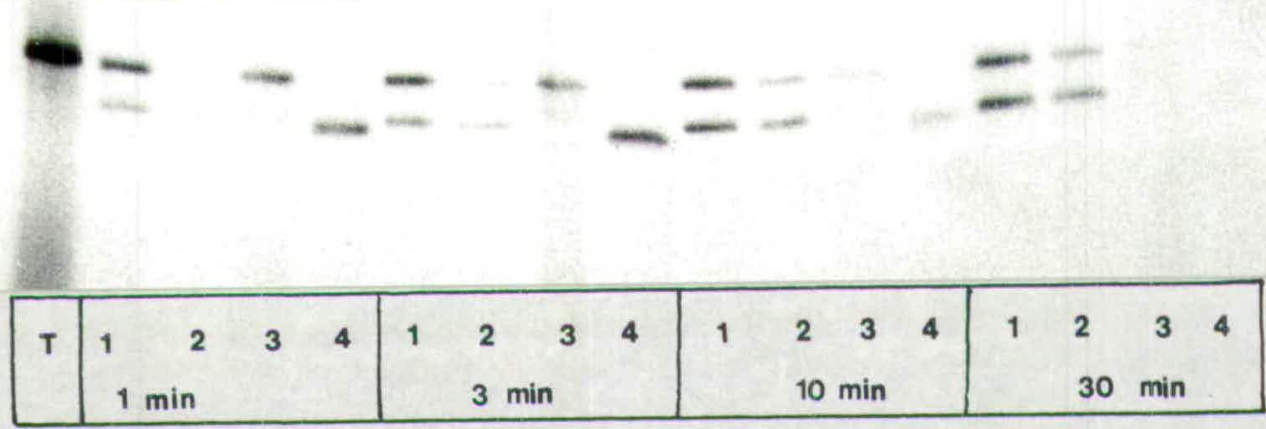

$\underline{18}$

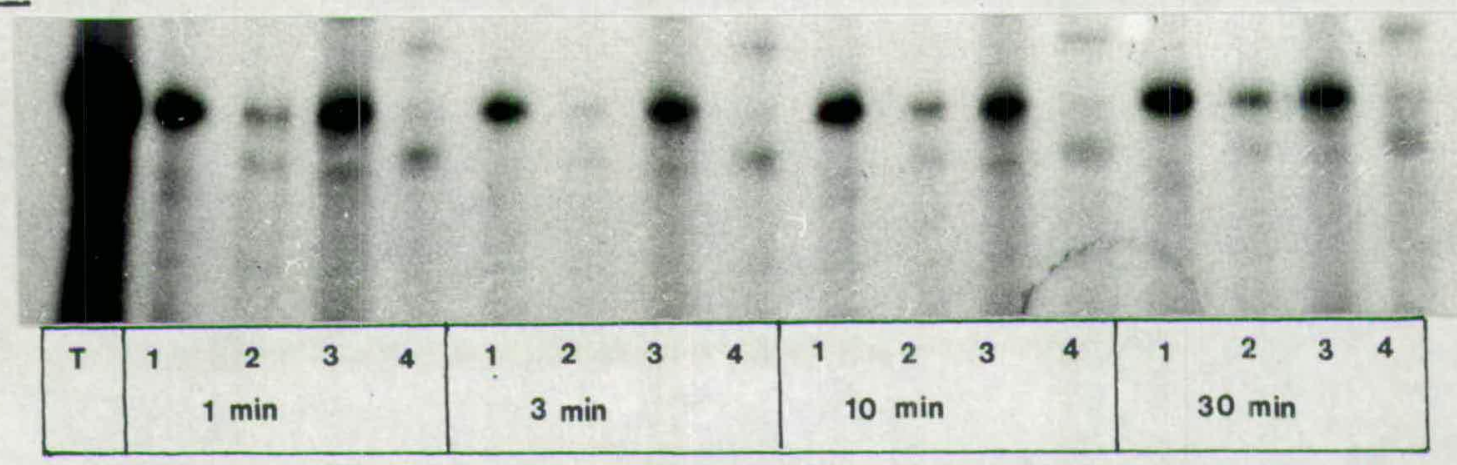

Wild type and mutant beta subunit-DHFR hybrid proteins were synthesised in vitro in the presence of ${ }^{35} \mathrm{~S}$ methionine in a volume of $27.5 \mu \mathrm{l}$. A sample of $5.5 \mu l$ was kept as the translation product $(T)$, and the remainder was incubated with isolated yeast mitochondria in a volume of $400 \mu 1$. At time intervals of $1 \mathrm{~min}, 3 \mathrm{~min}, 10 \mathrm{~min}$ and $30 \mathrm{~min}, 100 \mathrm{ul}$ aliquots were removed and put on ice. CCCP was added to a final concentration of $20 \mu \mathrm{M}$ to prevent further import. For each time point half of the sample was treated with proteinase $K(10 \mu \mathrm{g} / \mathrm{ml}$ final concentration) to determine the amount of precursor polypeptide transported. Mitochondrial and supernatant fractions were isolated, precipitated with $10 \%$ TCA and run on a SDS-12\% polyacrylamide gel. Radioactive tands were detected by fluorography. $(p)$ and $(m)$ indicate the precursor and mature forms of the hybrid proteins. 1, mitochondria minus protease; 2 , mitochondria plus protease; 3 , supernatant minus protease; 4, supernatant plus protease. 
subunit-DHFR to be taken up into isolated mitochondria within 3 minutes and partly processed to the mature form. Both mitochondrially associated precursor and mature proteins were resistant to added proteinase $\mathrm{K}$, which confirmed their correct localisation. Mitochondrial import of the I8 precursor was considerably slower, as only a small part of the radiolabelled protein was associated with the mitochondria. The protease-susceptibility of this material indicated that most of the precursor was on the mitochondrial surface. These preliminary results as shown in figure 5.6 suggest that membrane translocation of the mutant precursor polypeptide is significantly affected and thus that translocation may be rate limiting in protein import. However, an effect on proteolytic processing could not be excluded. Evidence from comparative sequence analysis of several imported mitochondrial proteins suggests that the information required for proteolytic maturation may reside in a particular protein conformation rather than an amino acid consensus sequence (Reid, 1985). Attempts to show processing of the wild type and mutant beta subunit-DHFR precursors by a mitochondrial lysate in vitro, in order to determine whether the mutations affected the translocation or processing steps, were unsuccessful.

The requirement of basic residues within the presequence for efficient delivery has been demonstrated in the mitochondrial proteins human ornithine transcarbamylase (Horwich et al., 1985b, 1986) and beta subunit of ATP synthase (Vassarotti et al., 1987a) using in vitro mutagenesis and deletion techniques. In the present study, the reduced rate of transport observed with mutants C1 and G5 could not be 
attributed to the removal of a single arginine residue by substitution at position 12 , as the same mutation in a single replacement (mutant N1) was transported efficiently (data not shown). It was not possible to test the requirement of positive charge by bisulphite mutagenesis in which all six basic residues within the first 35 amino acids were substituted. The nature of the mutations ( $\mathrm{C} \rightarrow \mathrm{T}$ transitions) meant that only a limited combination of substitutions was possible, and the isolation of single changes would require extensive screening. As an alternative approach, oligonuceotide site-directed mutagenesis has been used to construct single and multiple point mutations, and deletions in part of a single stranded DNA template, encoding the protein. Recent examples include human ornithine transcarbamylase, a matrix protein (Horwich et al., $1985 b, 1986$ ), beta subunit of $E$. coli ATPase (Parsonage et al., 1987 ) and influenza virus neuraminidase, a membrane protein (Sivasubramanian and Nayak, 1987).

Of the mutants which were transported and processed, most contained one to three amino acid changes, for example H64, H6, H13. Only in two cases (N7 and O35) which behaved as wild type, were there multiple changes distributed regularly in the first 15 residues of the presequence. The position of amino acid replacements would not be expected to significantly alter the hydrophobic nature of a defined region of the presequence. All twelve mutants fit the amphiphilic helix model proposed by von Heijne (1986) as a requisite for transport of precursor proteins across the mitochondrial membranes.

An interesting feature noted in the mutant $\mathrm{C} 1$, was the effect of substituting serine ${ }_{11}$ with phenylalanine on the 
Fiqure 5.7 .

EFFECT OF PHENYLALANINE SUBSTITUTION ON THE ELECTROPHORETIC MOBILITY OF PRECURSOR PROTEIN TO MUTANT CI 3 BHFR.

SDS-PAGE

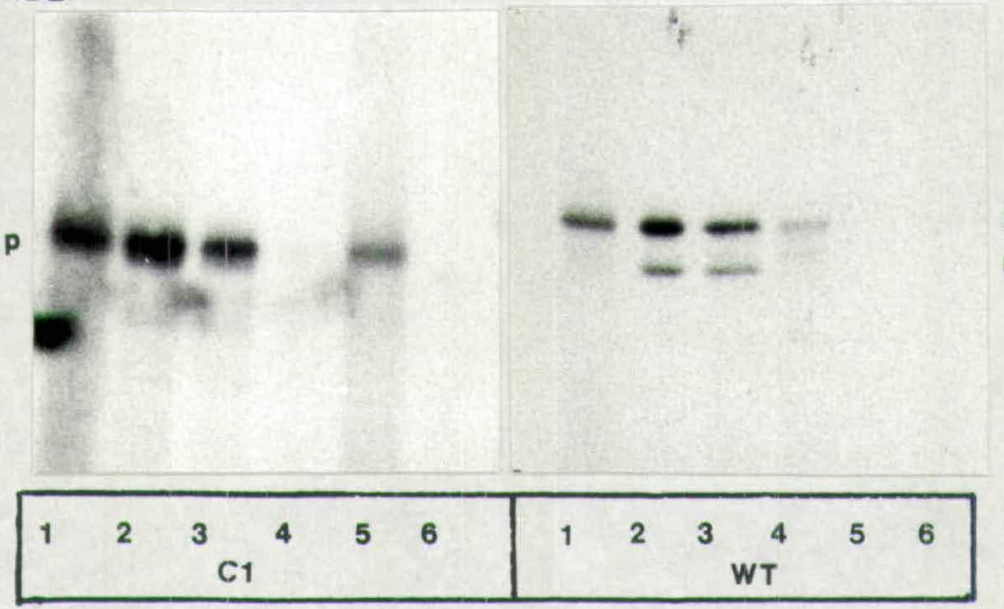

$6 M$ Urea-PAGE

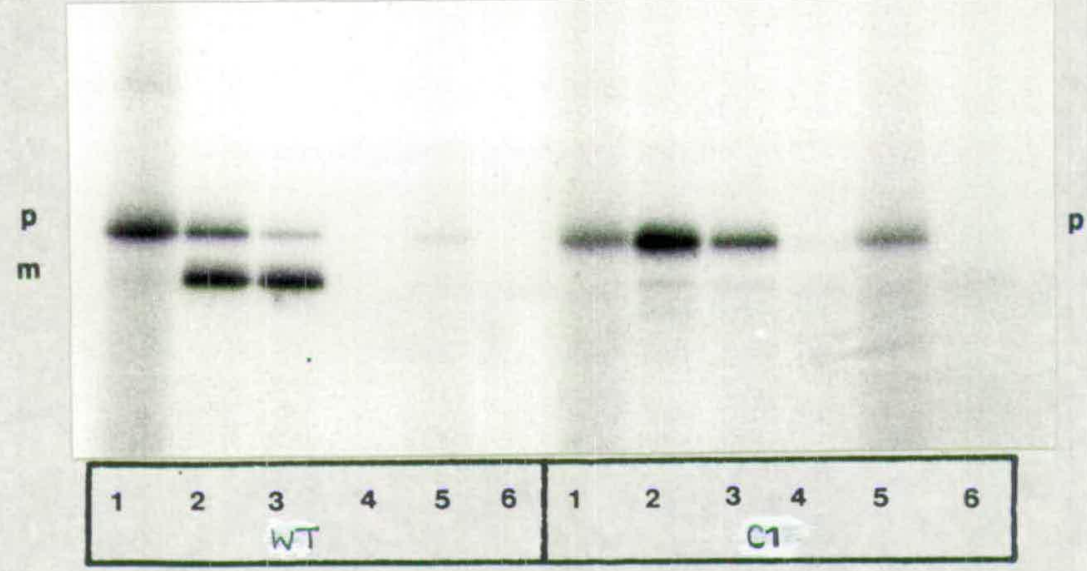

Mutant $\mathrm{C} 1$ and wild-type fusion proteins were synthesised in vitro and incubated with energised yeast mitochondria for $30 \mathrm{~min}$ at $28^{\circ} \mathrm{C}$. The import mixture was incubated for $15 \mathrm{~min}$ $\left(O^{\circ} \mathrm{C}\right)$ in the absence or presence of proteinase $K$ and detergent. The isolated mitochondrial and supernatant fractions were precipitated with TCA and run on a SDS $-12 \%$ polyacrylamide gel or a $12 \%$ polyacrylamide gel containing $6 \mathrm{M}$ urea. The apparant affect on electrophoretic mobility is seen in the presence of SDS. Lanes 1, translation product; 2, plus mitochondria; 3. plus mitochondria, proteinase $k$; 4, mitochondria, plus proteinase $K$, and Triton X-100; 5, supernatant; 6, supernatant plus proteinase K. Precursor and mature forms of the hybrid proteins are indicated by $p$ and $m$. 
electrophoretic mobility of the precursor polypeptide. DNA restriction analysis of the gene construct confirmed that the chimeric gene in plasmid pDS6 was not altered during amplification in $E$. coli. The apparent increased mobility which may reflect an altered protein conformation, was only observed under electrophoresis using SDS denaturing conditions and not in the presence of $6 \mathrm{M}$ urea, as shown in figure 5.7 (Andrews, 1983). Another mutant G5, which had a similar pattern of substitutions with the exception of the phenylalanine change, behaved as the wild type fusion. Such effects on protein mobility are observed in bacterial secretory proteins. Lunn and Inouye (1987) observed an altered mobility associated with certain mutations in hybrid proteins containing the signal sequence of prolipoprotein attached to beta-lactamase. These mutations either altered the basic amino acids in the extreme $\mathrm{N}$-terminus or and the hydrophobic core of the prolipoprotein signal sequence.

It can be concluded that the mitochondrial presequence of ATP synthase beta subunit contains the necessary information for correct targeting and import. The targeting information appears to reside in two protein sequences which can act independently. Furthermore, a high proportion of amino acid substitutions were found to be tolerated within the first 15 amino acids of the presequence. The majority of mutants tested as hybrid beta subunit-DHFR proteins were transported and proteolytically cleaved to the mature protein in vitro. Three mutants with multiple mutations in the carboxy-terminal half of the presequence were not processed, and indicate that the information required for correct processing of the presequence 
is located in a large region overlapping the cleavage site. Sequences distal to this site in the mature protein have also been demonstrated by deletion analysis to be required for proteolytic maturation (Vassarotti et al., 1987a). These results provide evidence for structural recognition of the precursor polypeptide by the matrix endoprotease.

\subsection{EFFECT OF AMINO ACID CHANGES ON TARGETING OF THE PRECURSOR} POLYPEPTIDE.

Gene fusions between the beta subunit presequence and the mouse cytosolic DHFR protein have demonstrated that the first 15 amino acids of the mitochondrial presequence are sufficient to direct import of the hybrid protein into mitochondria in vitro and in vivo. The structural requirements of the targeting signal for the delivery of authentic precursor to beta subunit was further examined in vivo. The in vivo approach was adopted since it was possible that the lack of a clear effect on transport associated with the mutations in the in vitro assay may not reflect the situation in the cell, where the efficiency of targeting may be more critical. The possibility of a mutant targeting sequence having different effects on transport depending on the attached protein could also be avoided. The first 35 codons of the wild type ATP2 gene encoding the beta subunit precursor, was replaced by the different mutant ATP2 sequences from the ATP2-DHFR chimeric genes described in Chapter 5.1. The mutant precursors were assayed for correct import and proteolytic cleavage by complementation of the plasmid-borne mutated genes transformed into an atp2 yeast mutant lacking beta 
Table 5.4. PLATE ASSAY USED TO SCREEN MUTANT TARGETING SEQUENCES EXPRESSED IN atP2 YEAST MUTANT JQ1.

\begin{tabular}{|c|c|c|c|}
\hline YEAST STRAIN & YPO & YPEG & SD + his \\
\hline JQ1 & ++ & - & - \\
JQ1(PFL1-11-3) & +++ & +++ & ++ \\
JQ1(PMC4F1) & +++ & +++ & ++ \\
JQ1(H63) & +++ & ++ & ++ \\
JQ1(H64) & + & - & + \\
JQ1(H6) & ++ & ++ & ++ \\
JQ1(H5) & + & - & + \\
JQ1(H2) & ++ & - & ++ \\
JQ1(H28) & ++ & - & + \\
JQ1(H13) & ++ & ++ & ++ \\
JQ1(C1) & + & - & + \\
JQ1(I8) & ++ & - & + \\
JQ1(G5) & ++ & - & ++ \\
\hline
\end{tabular}

JQ1 and transformed cells possessing plasmid-encoded wild type beta subunit ( $P F L 1-11-3$ and $P M C 4 F 1 \beta$ ) and mutant beta subunit ( $M M C 4 F 1 \beta$ ) were grown from single colony on $2 \%$ glucose (YPD), $3 \%$ ethanol and $2 \%$ glycerol (YPEG) and $5 D$ + histidine minimal medium plates for seven days at $30^{\circ} \mathrm{C}$. Growth was scored qualitatively as follows: no growth $(-)$, poor growth $(+)$, good growth $(++)$, and very good growth $(+++)$. Those transformants expressing beta subunit which is transported into the mitochondrion and assembled into a functional ATP synthase, will complement the atp 2 mutation in JQ1 and grow on nonfermentable carbon sources such as ethanol and glycerol. 


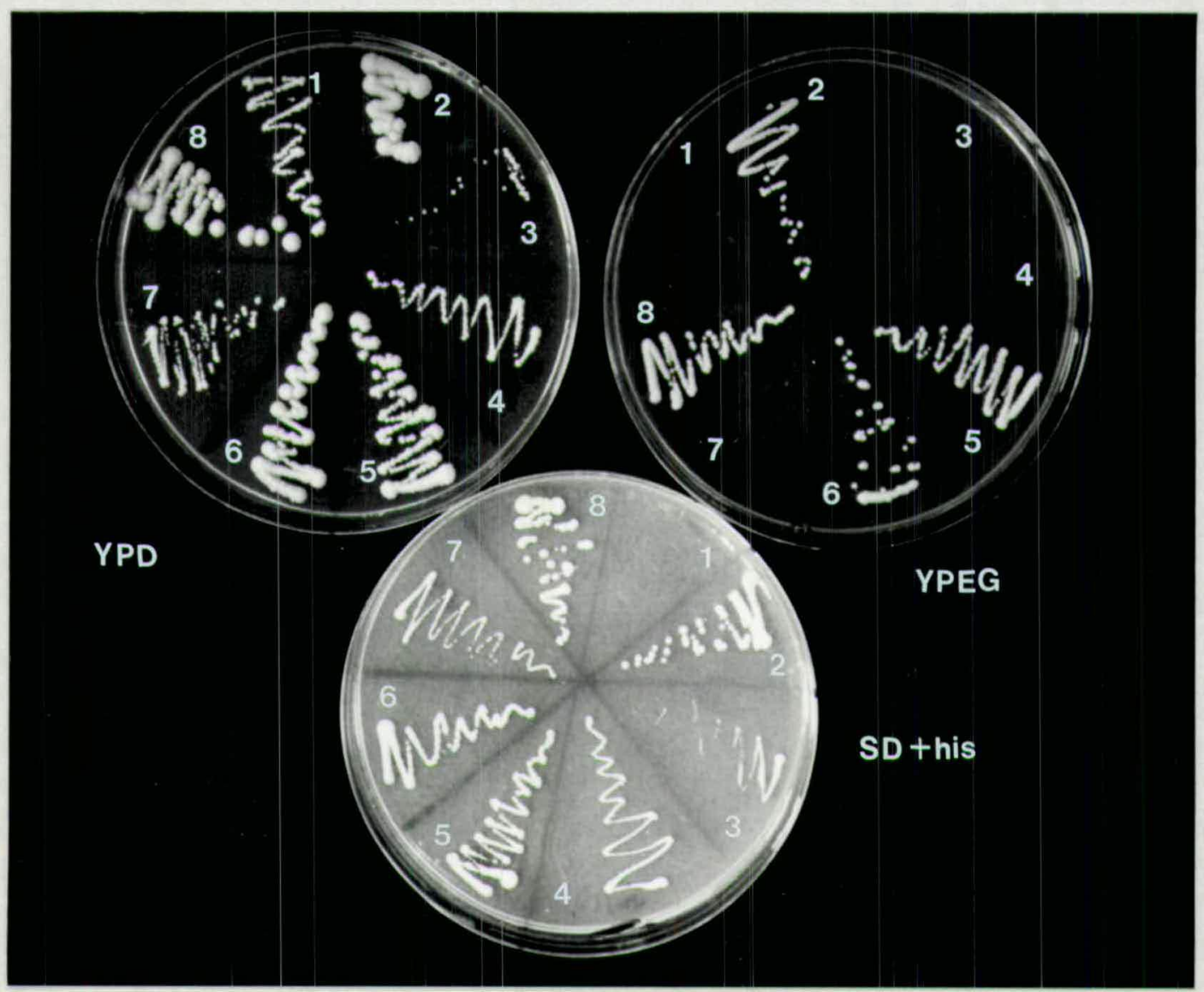

JQ1, a beta subunit deficient yeast mutant was transformed with the autonomously replicating centromere plasmid pMC $4 \mathrm{~F} 1 \beta$, in which the yeast alcohol dehydrogenase ( $\mathrm{ADH} 1$ ) promoter directed expression of genes encoding wild type and mutant beta subunit. Cells from single colonies were streaked onto uracil-free SD plates (SD + his) containing $0.17 \%$ yeast nitrogen base, $2 \%$ glucose and $50 \mu \mathrm{g} / \mathrm{ml}$ L-histidine, or YPD plates containing $1 \%$ yeast extract, $2 \%$ peptone and $2 \%$ glucose or YPEG plates containing $1 \%$ yeast extract, $2 \%$ peptone, $2 \%$ glycerol and $3 \%$ ethanol. After 5 days growth at $30^{\circ} \mathrm{C}$, the plates were photographed.

1. JQ1; 2. JQ1 (pFL1-11-3);3. JQ1(L1); 4.JQ1(I8); 5. JQ1(H6),

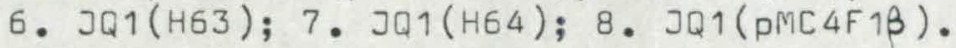


subunit protein and ATPase activity. The mutant ATP2 genes were cloned in pMC4-F1 $\beta$, and were introduced by transformation into Saccharomyces cerevisiae JQ1 (MATX, his', atp2::LEU2, ura-). $\mathrm{URA}^{+}$transformants were picked and screened by plate assay for mutant targeting sequences that are functional in transport.

A plate assay was developed to screen mutant targeting sequences expressed in JQ1. The disruption of the chromosomal ATP2 gene in JQ1, eliminated expression of beta subunit and oxidative phosphorylation with the consequent inability to grow on glycerol and ethanol as sole carbon sources. Respiration in the atp2- strains GR1 (MATX, his-, atp2::URA3, leu-) and JQ1 was restored by expression of wild type beta subunit after transformation with plasmids encoding the ATP2 gene. URA transformants possessing the mutant pMC4-F1 $\beta$ plasmids were plated on glucose (YPD), and ethanol/glycerol (YPEG) for growth on non-fermentable carbon and $\mathrm{SD}+$ his minimal medium for plasmid selection. As the mutants have an unaltered mature protein sequence which is catalytically functional, the delivery and assembly of F1 with other ATP synthase subunits in the mitochondrion, would enable growth on glycerol and ethanol as sole carbon sources. The results are described in table 5.4 , and figure 5.8. Mutants $\mathrm{H} 64$, $\mathrm{H} 5$ and $\mathrm{H} 2$, which were transported in vitro as beta subunit-DHFR hybrid proteins, did not complement the atp2 lesion in vivo when expressed as authentic precursor to beta subunit. Figures $5.9-5.14$ show growth curves of the various mutant yeast grown in SD medium and YPDG, as compared with wild type strains. Only in those mutants which complement the atp2 defect are able to grow on glycerol to a final optical density as that of wild type. The remainder which do not 


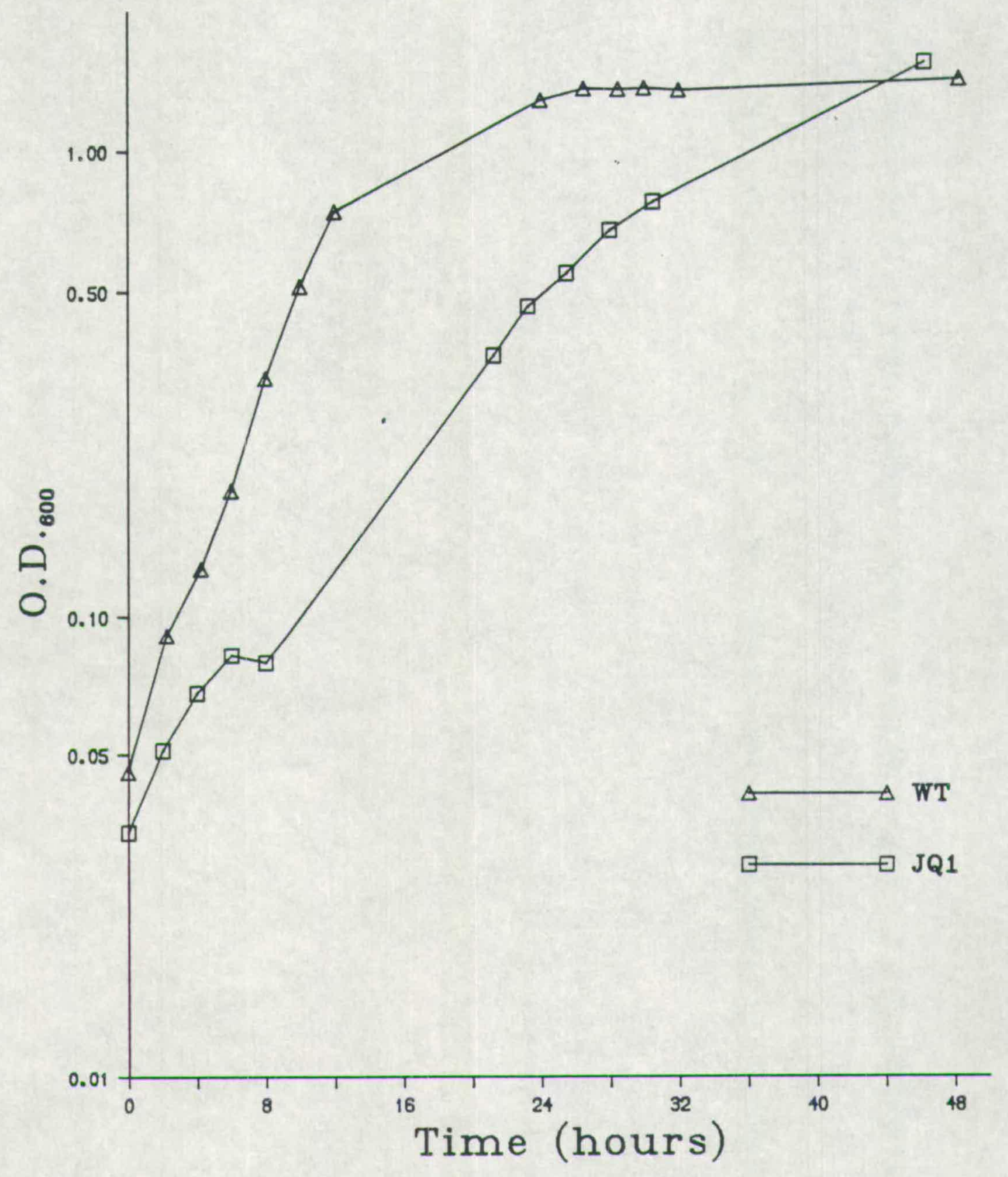

Figure 5.9

Growth curves of yeast transformants expressing mutant forms of the $F_{1} \beta$ subunit in SD medium. 


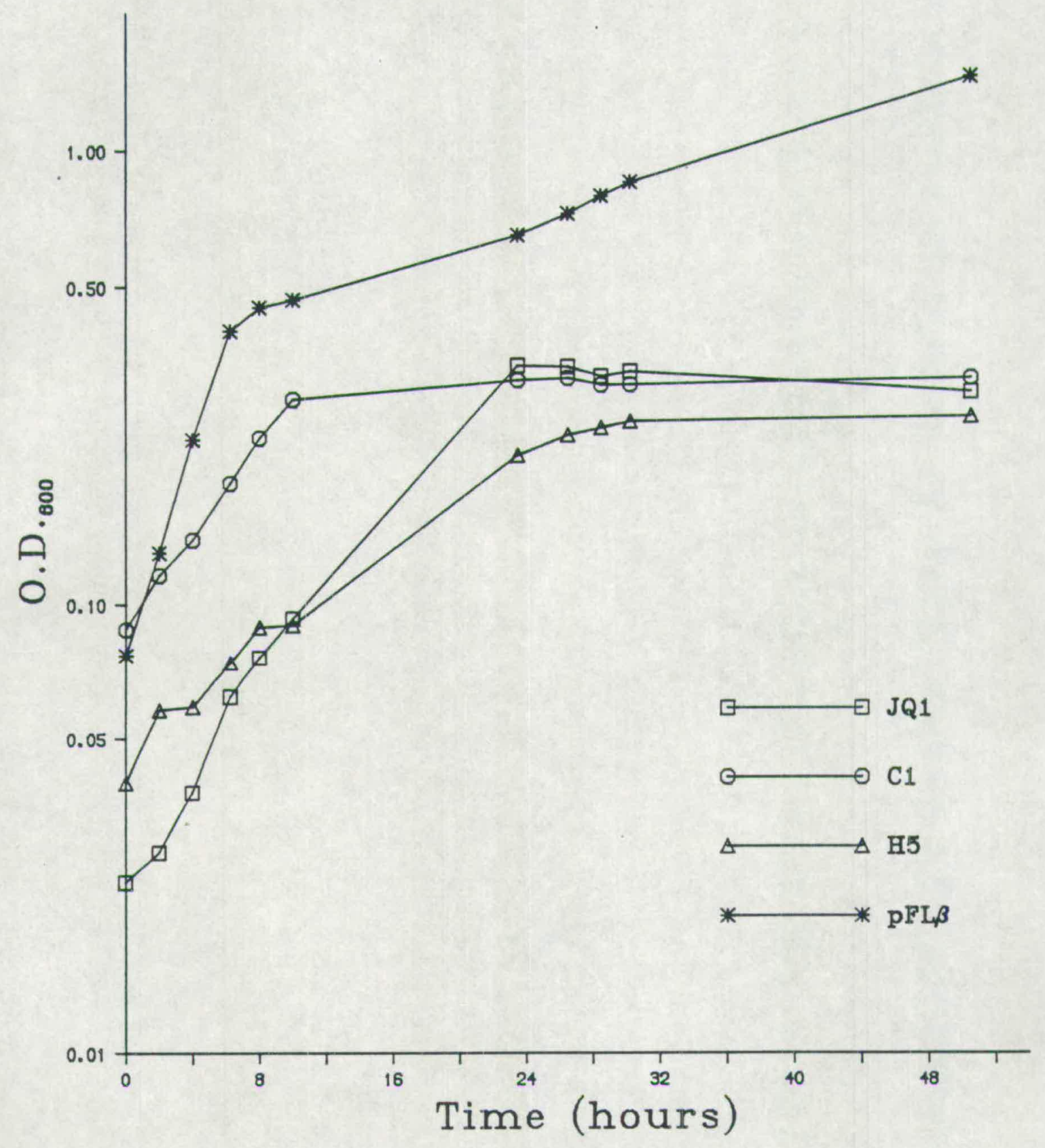

Figure 5.10

Growth curves of yeast transformants expressing mutant forms of the $F_{1} \beta$ subunit in YPDG medium. 


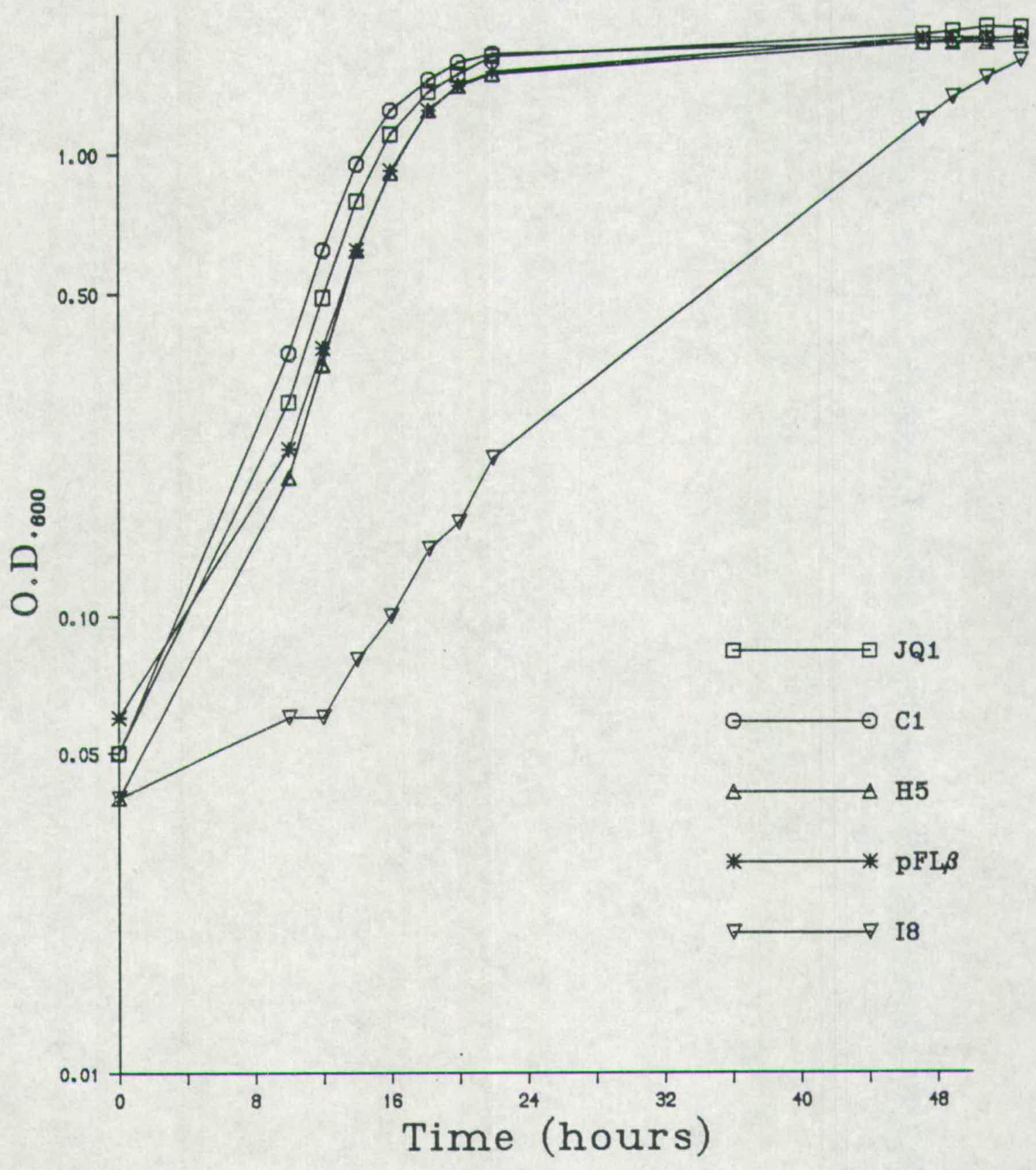

Figure 5.11

Growth curves of yeast transformants expressing mutant forms of the $F_{1} \beta$ subunit in SD medium. 


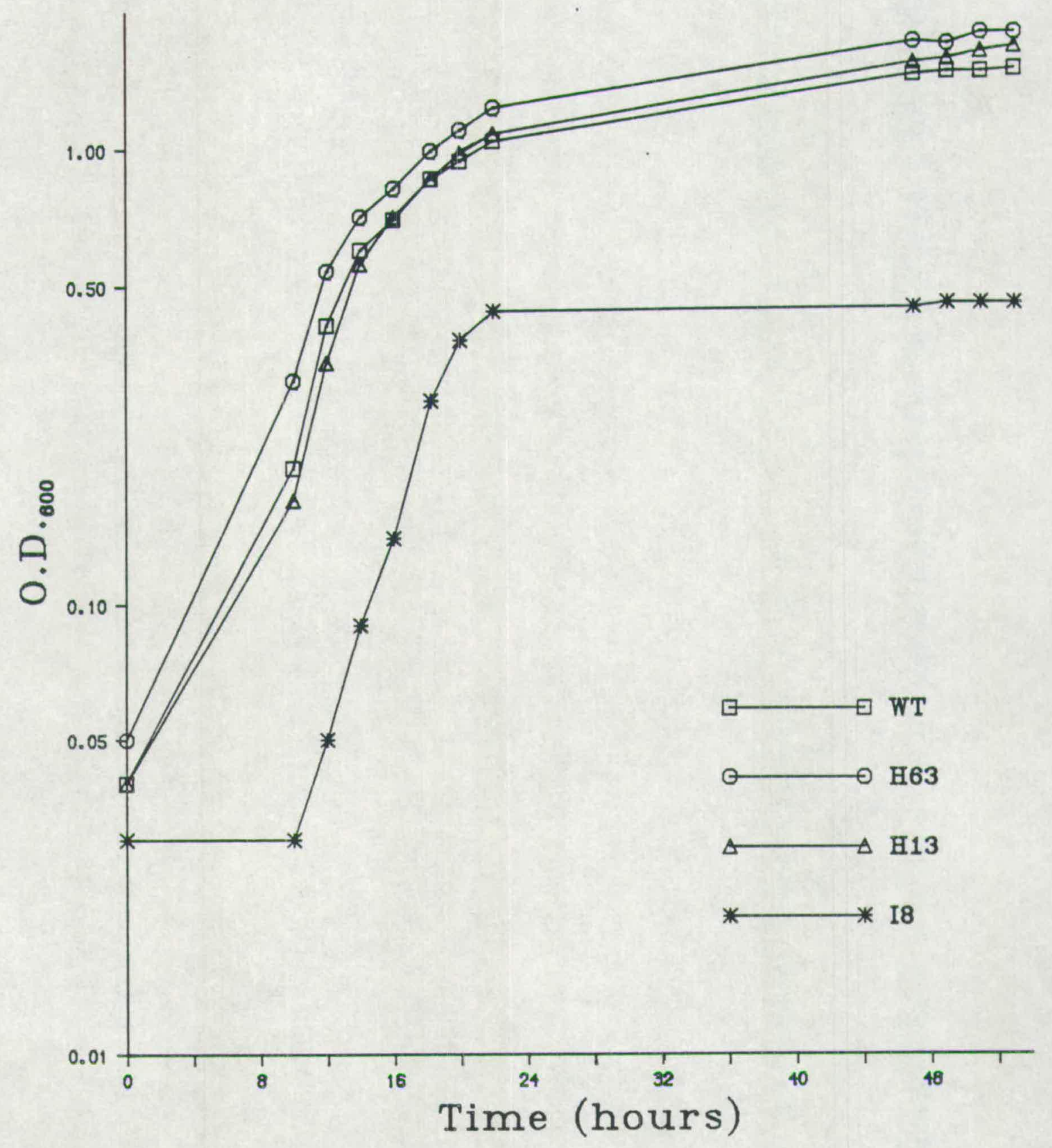

Figure 5.12

Growth curves of yeast transformants expressing mutant forms of the $F_{1} \beta$ subunit in YPDG medium. 


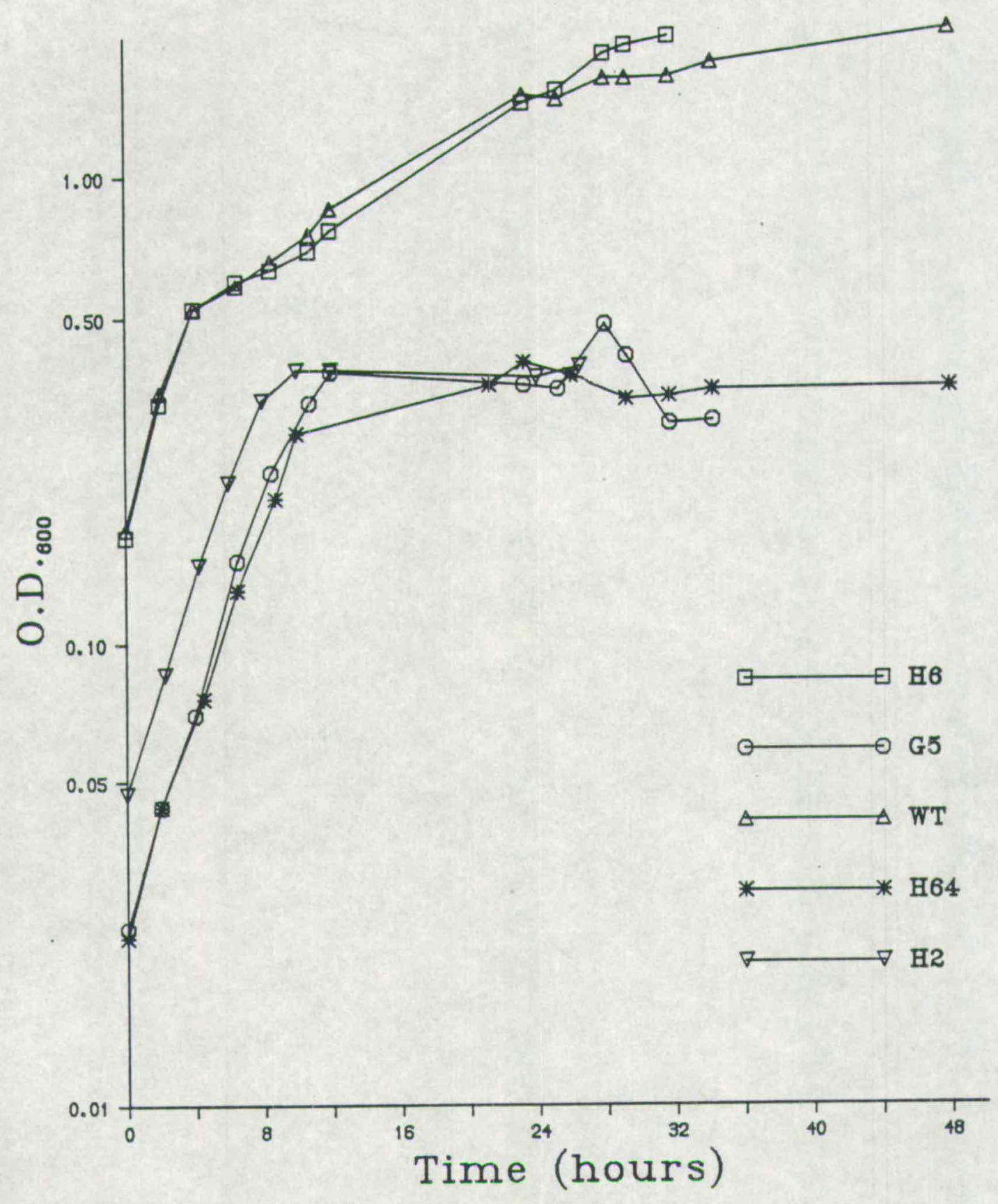

Figure 5.13

Growth curves of yeast transformants expressing mutant forms of the $F_{1} \beta$ subunit in YPDG medium. 


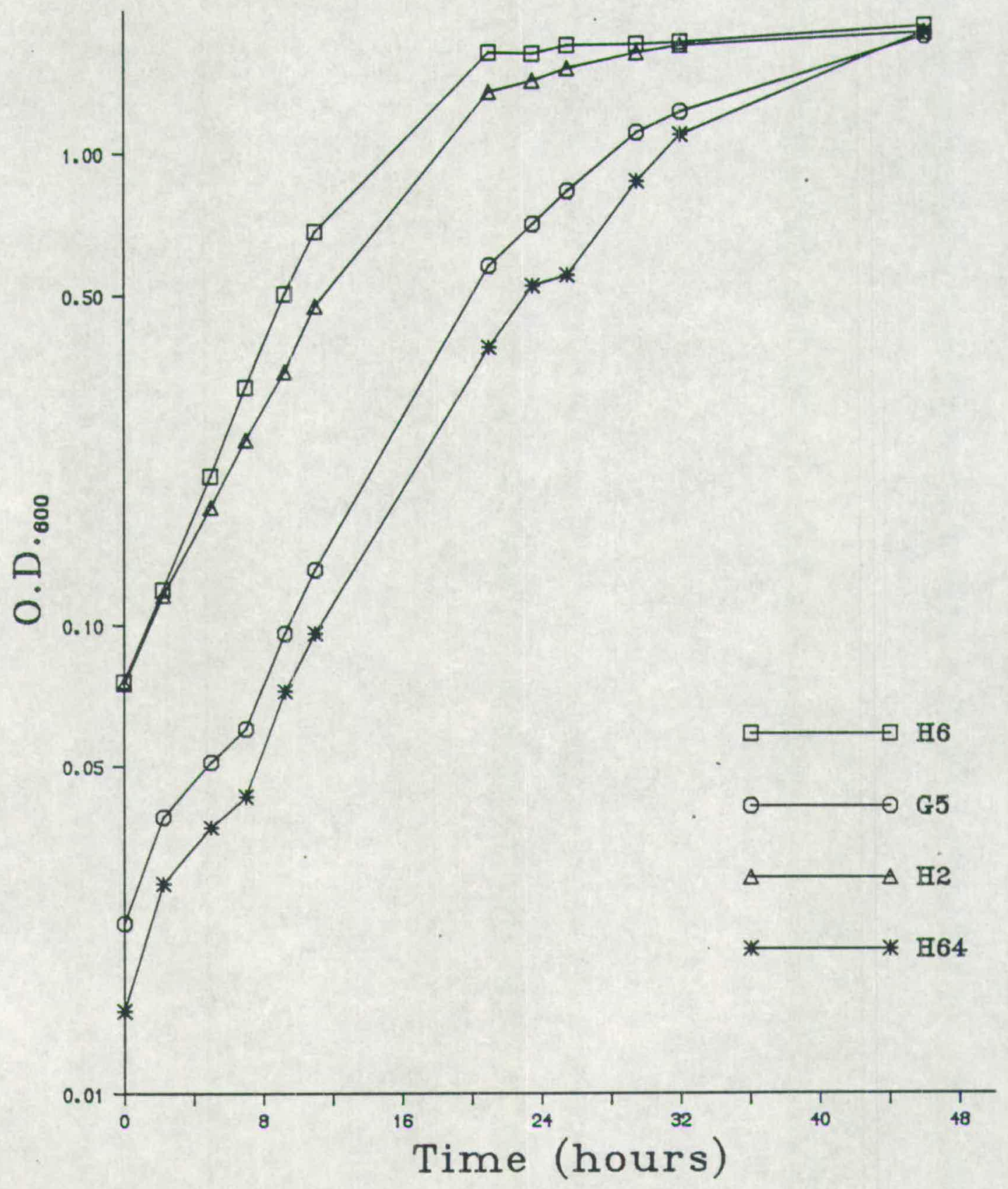

Figure 5.14

Growth curves of yeast transformants expressing mutant forms of the $F_{1} \beta$ subunit in SD medium. 
complement have growth rates similar to the atp2 mutant JQ1. The interesting exception was that of the I8 mutant, where growth on both glycerol and minimal medium supplemented with glucose was poor. As growth on glucose does not require oxidative phosphorylation, the untransformed host JQ1 lacking beta subunit, as expected, grew as fast as the transformants expressing active beta subunit. The negative growth effect shown by the I8 mutant suggests that the beta subunit polypeptide may be interfering with some mitochondrial function other than oxidative phosphorylation.

The steady state levels of $F 1 \beta$ subunit in the various transformants were determined by Western blot analysis of cell extracts from stationary phase cultures grown in SD and YPDG or $0.1 \%$ YPD medium. Beta subunit was detected in each case with the exception of H5, although the amount synthesised varied. In most mutants (excluding $\mathrm{H} 64, \mathrm{H} 5$, and $\mathrm{C} 1$ ) the level of antigen detected was comparable to wild type. No detectable protein was observed for $\mathrm{H} 5$ and in mutants $\mathrm{H} 64$ and $\mathrm{C} 1$ the antigen was only found in cells grown in SD medium (figures 5.15 and 5.16 ). Therefore, it is likely that under respiratory conditions the lack or reduced level of particular mutant polypeptides may be due to an increased rate of degradation of the precursor form or decreased rate in synthesis. In the limited time available, it was not possible to test this using Northern analysis of mRNA transcripts or Western blot analysis of proteins at different growth stages. However, the inability to complement the atp2 mutation in mutants $\mathrm{H} 2, \mathrm{G} 5$ and $\mathrm{I} 8$ could not be attributed to effects on protein expression as the levels of mature (and therefore, mitochondrial associated) beta subunit were 
EXPRESSION OF MUTANT BETA SUBUNIT IN YEAST GROWN IN SD MINIMAL MEDIUM SUPPLEMENTED WITH $2 \%$ GLUCDSE.

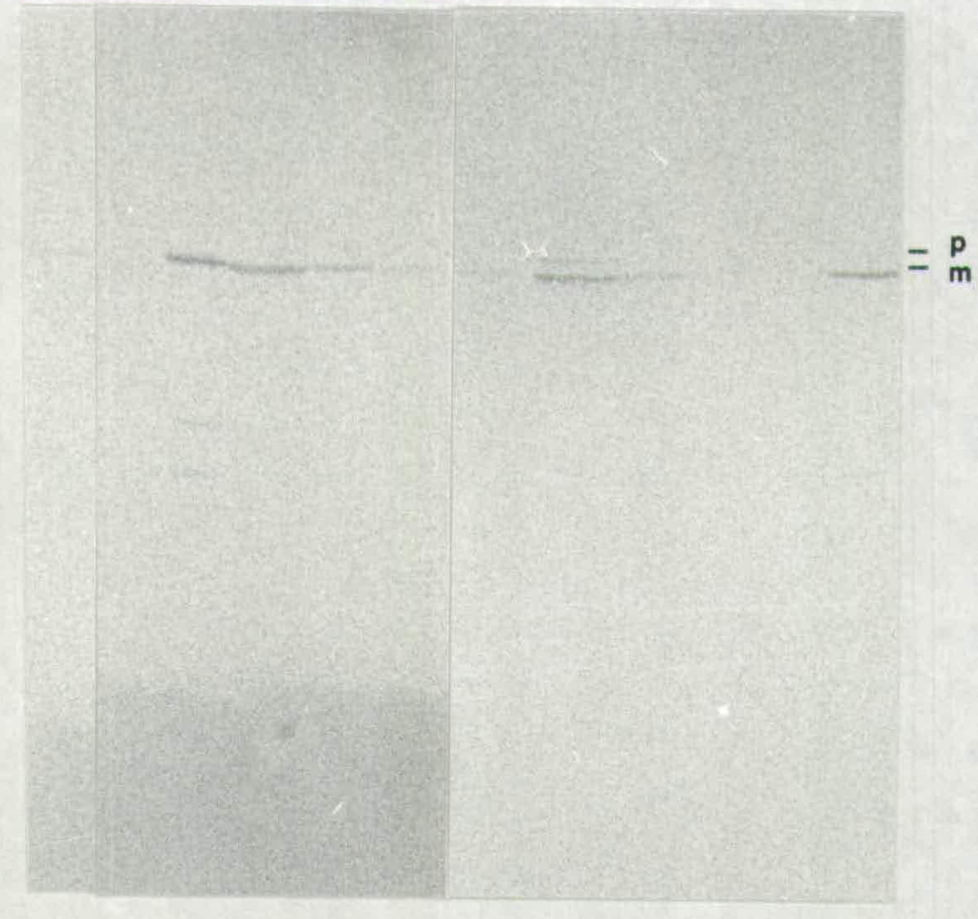

$\begin{array}{llllllllllll}1 & 2 & 3 & 4 & 5 & 6 & 7 & 8 & 9 & 10 & 11 & 12\end{array}$

\footnotetext{
Yeast strains SF747, JQ1 and transformants with plasmid-encoded wild type and mutant beta subunit, were grown to stationary phase in SD minimal medium supplemented with $2 \%$ glucose. Protein extracts were made by breaking the cells with glass beads and $10 \%$ TCA. The precipitates were washed in ethanol, dried and solubilised in SDS sample buffer containing 1\% 2-mercaptoethanol by boiling for $3 \mathrm{~min}$. After spinning for $1 \mathrm{~min}$, equal amounts of total protein were run on a $10 \%$ polyacrylamide gel in the presence of SDS. Proteins were transferred onto nylon membrane and immunodecorated with antisera to $F / \beta$ subunit, followed by horseradish peroxidase-conjugated second antibody. The data presented was from two experiments: Lanes 1. SF747; 2. JQ1; 3. JQ1 (pFL1-11-3); 4. JQ1 (pMC4F1B); 5. JQ1(H63); 6. JQ1(H64); 7. JQ1(H2); 8. JQ1(I8); 9. JQ1(G5); 10. JQ1(C1); 11. JQ1(H5); 12. JQ1(H6). $(p)$ and $(m)$ indicate the precursor ( $56 \mathrm{kDa}$ ) and mature ( $54 \mathrm{kDa}$ ) forms of the beta subunit of yeast ATP synthase.
} 
Fiqure 5.16.

EXPRESSION OF MUTANT BETA SUBUNIT IN YEAST GROWN IN $0.1 \%$ YPD AND YPDG MEDIUM.

$0.1 \%$ YPD MEDIUM.

YPDG MEDIUM.
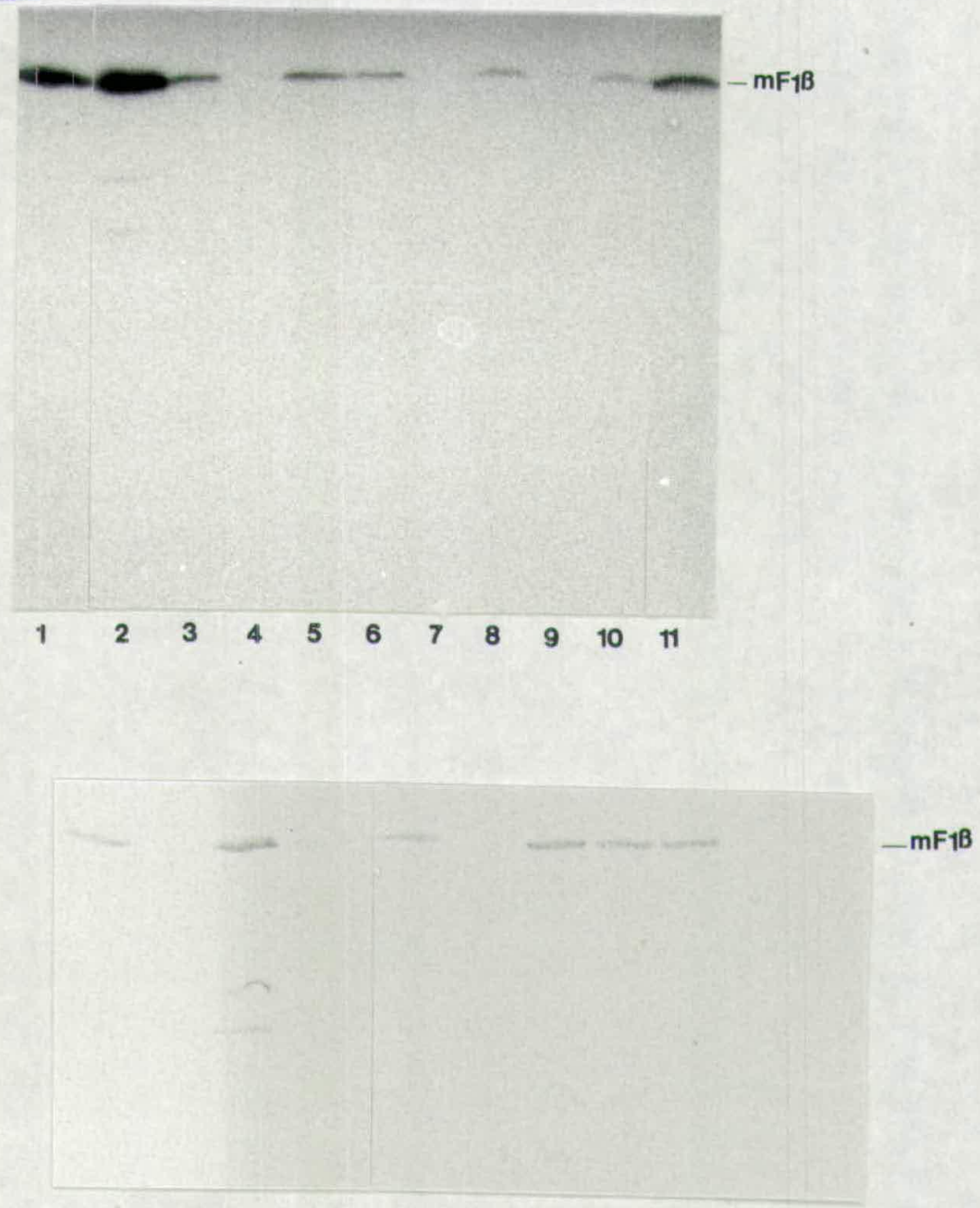

$\begin{array}{lllllllllll}1 & 2 & 3 & 4 & 5 & 6 & 7 & 8 & 9 & 10 & 11\end{array}$

Yeast strains SF747, JQ1 and transformants with plasmid-encoded wild type and mutant beta subunit, were grown in $0.1 \%$ YPD

( $1 \%$ yeast extract, $2 \%$ bactopeptone, $0.1 \%$ glucose) and YPDG

( $1 \%$ yeast extract, $2 \%$ bactopeptone, $0.1 \%$ glucose, $3 \%$ glycerol). Protein extracts were prepared as described in Materials and Methods, and equal amounts of total protein were Iun on a $10 \%$ polyacrylamide gel in the presence of SDS. Proteins were transferred onto nylon membrane, and immunodecorated with antisera to F1Bsubunit, followed by either ${ }^{125}$ I Protein A and autoradiography, or horseradish peroxidase-conjugated second antibody. The results for growth on $0.1 \%$ YPD are as follows: 1. 5F747; 2. JQ1 ( pFL1-11-3); 3. JQ1 (pMC4F1B); 4. JQ1(pMC4); 5. JQ1(H2); 6. JQ1(I8); 7. JQ1(C1); 8. JQ1(H63); 9. JQ1(H64); 10. JQ1(H13); 11. JQ1 (HG).

The results for growth on YPDG are as follows: 1. SF747;

2. JQ1; 3. JQ1 (pFL1-11-3); 4. JQ1(PMC4F13); 5. JQ1(H6); 6. JQ1(H3);

7. JQ1(H2);8.JQ1(G5); 9. JQ1(I8); 10. JQ1(C1); 11. JQ1(H13). 


\section{Fiqure 5.17 .}

\section{SUBCELLULAR FRACTIONATION STUDIES: MUTANT BETA SUBUNIT PROTEIN}

IS TRANSPORTED TO THE MITOCHONDRION IN VIVO.

\begin{tabular}{|c|c|c|c|c|c|c|c|c|c|c|c|c|c|c|c|c|c|c|c|}
\hline ஜํำ & हु & $\underline{3}$ & $\stackrel{8}{2}$ & $\frac{g}{y}$ & ฮ & $\underline{\underline{z}}$ & 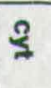 & क्ष & శ్ & 클 & $\stackrel{\Omega}{\Xi}$ & $\frac{\phi 10}{9}$ & ठ & 吾 & 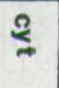 & $\frac{90}{y}$ & छ & $\underline{\underline{3}}$ & 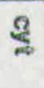 \\
\hline & & & & \multicolumn{4}{|c|}{ H63 } & \multicolumn{4}{|c|}{ H64 } & \multicolumn{4}{|c|}{ H2 } & \multicolumn{4}{|c|}{$\mathrm{H13}$} \\
\hline
\end{tabular}

\begin{tabular}{|c|c|c|c|c|c|c|c|c|c|c|c|}
\hline$\frac{9}{3}$ & $\underline{\exists}$ & @ & $\frac{98}{9}$ & $\underline{\underline{3}}$ & $\stackrel{\varrho}{\Perp}$ & ㅎํㄱ & $\underline{3}$ & 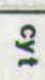 & $\frac{10}{7}$ & $\underline{\underline{3}}$ & $£$ \\
\hline \multicolumn{3}{|c|}{ WT } & \multicolumn{3}{|c|}{$\mathrm{H} 63$} & \multicolumn{3}{|c|}{ H64 } & \multicolumn{3}{|c|}{$\mathrm{H} 2$} \\
\hline
\end{tabular}

\begin{tabular}{|c|c|c|}
\hline ํㅜㅁ & $\underline{\underline{3}}$ & 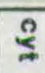 \\
\hline & $\mathrm{H13}$ & \\
\hline
\end{tabular}

\begin{tabular}{|c|c|c|c|c|c|c|c|c|c|c|c|c|c|c|c|c|c|c|c|}
\hline 尊 & ฮू & $\underline{\underline{3}}$ & ? & $\frac{\mathbb{B}}{g}$ & ฮ & $\underline{3}$ & 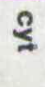 & 뿍 & ప్ & $\underline{\underline{3}}$ & 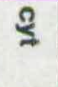 & $\frac{8}{9}$ & శ్ & $\underline{\underline{\underline{3}}}$ & $\stackrel{?}{\leq}$ & 禺 & Ј & 3 & $£$ \\
\hline \multicolumn{4}{|c|}{ WT } & \multicolumn{4}{|c|}{ H63 } & \multicolumn{4}{|c|}{ H64 } & \multicolumn{4}{|c|}{$\mathrm{H} 2$} & \multicolumn{4}{|c|}{$\mathrm{H} 13$} \\
\hline
\end{tabular}

Yeast cells transformed with the plasmids pmC $4 F 1 \beta$, encoding wild-type and mutant beta subunit protein were grown in liquid SD minimal medium containing $2 \%$ glucose and fractionated into spheroplasts (sph), homogenate (hom), mitochondria (mit), and post-mitochondrial supernatant (cyt) as described in Materials and Methods. Equal amounts of protein as estimated by PAGE blue staining were analysed by $5 D S-12 \%$ polyacrylamide gel electrophoresis and immune blotting using antisera against beta subunit $\left(F_{1} \beta\right)$, cytochrome $b_{2}$ ( $b_{2}$, mitochondrial marker) and yeast hexokinase (HK, cytosolic marker). Mutants G5, H6, C1 and I8 (data not shown) were directed to the mitochondrion and processed to the mature form by the matrix-located endoprotease. 
comparable with wild type. Sequence data has shown that in some of the mutants which do not complement there was a single base change which may have an effect on translation (Table 5.2).

To determine whether the amino acid changes affected normal targeting and import, cell fractionation studies were carried out on a number of mutants grown in $2 \%$ glucose (SD + his medium) for optimal expression of the ATP2 gene under control of the $A D H 1$ promoter. Western blot analysis using antisera to marker enzymes of the cytosol (yeast hexokinase), and mitochondria (cytochrome $b_{2}$ and F1 $\beta$ subunit) were used to determine the purity of fractionation and mitochondrial damage (as shown in figure 5.17 ). The majority of the mutant polypeptides tested were correctly imported and targeted to the matrix where maturation occurred. The only exception was mutant H5, which had no immunologically detectable protein. The proportion of precursor and mature forms noted in various experiments were comparable to wild type.

The effects of amino acid changes on the kinetics of processing was assessed in mutants $\mathrm{H} 13$ and I8 as compared with F1 $\beta$ subunit. The import of beta subunit precursor was followed by the production of mature F1 $\beta$ subunit by the matrix-located protease using pulse-labelling. Logarithmically growing cells were pulse-labelled with $\left[{ }^{35} \mathrm{~S}\right]$ methionine for seven minutes and chased for one hundred minutes. The beta subunit protein was immunoprecipitated from the cell extract and run on polyacrylamide gels. All the wild type protein was matured within the pulse and imported. Maturation of H13 was slower although $50 \%$ of the precursor form was processed during the labelling period and was completely imported within 5 minutes of 
Fiqure 5.18 .

KINETICS OF PROCESSING AND IMPORT OF MUTANT BETA SUBUNIT PROTEIN EXPRESSED IN AN atp2 YEAST MUTANT, LACKING BETA SUBUNIT: PULSE LABEL-CHASE STUDIES.

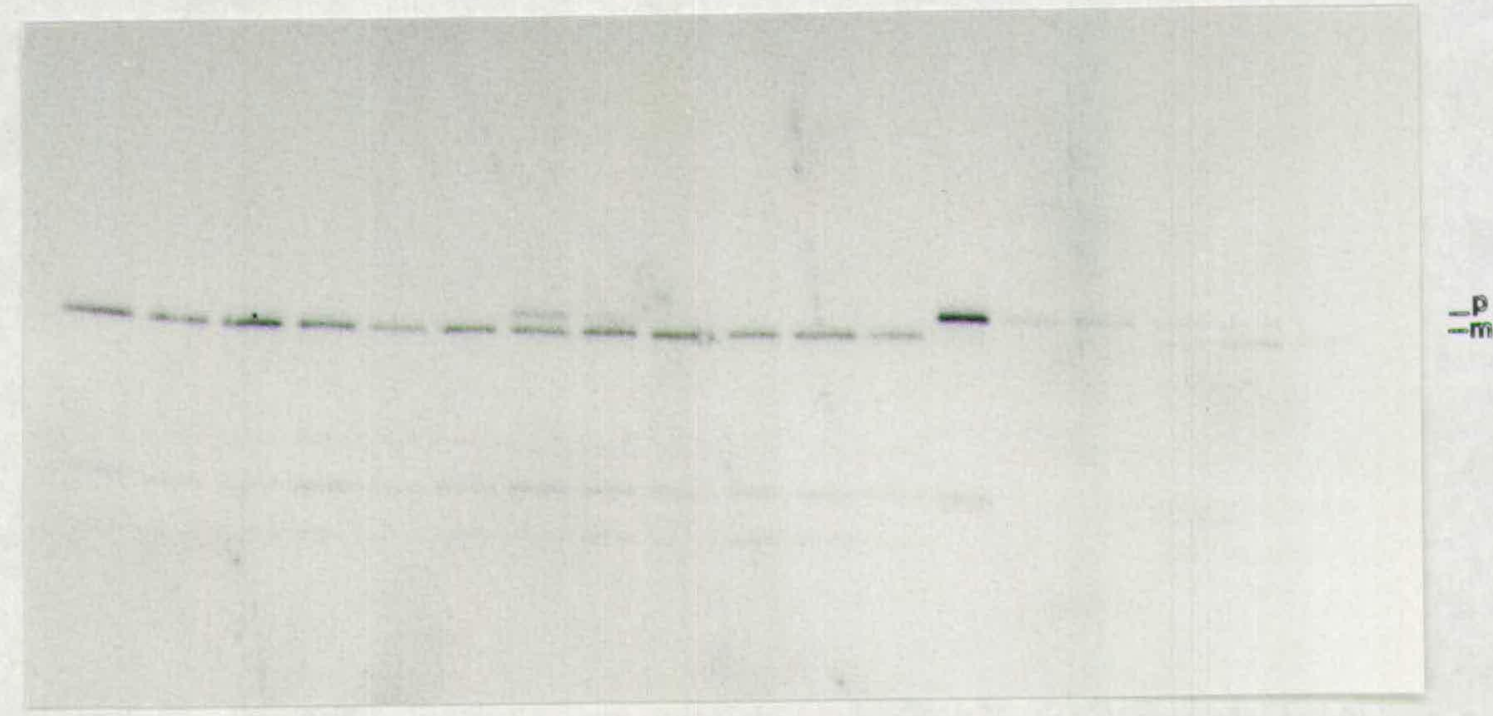

\begin{tabular}{|llllll|lllllll|lllllll|}
\hline 0 & 2 & 5 & 10 & 20 & 50 & 0 & 2 & 5 & 10 & 20 & 50 & 0 & 2 & 5 & 10 & 20 & 50 \\
\hline & WT & & & & & & & $H 13$ & & & & & & 18 & & \\
\hline
\end{tabular}

JQ1, a beta subunit deficient yeast mutant was transformed with the autonomously replicating centromere plasmid pMC $4 F 1 \beta$, encoding mutant and wild-type beta subunit protein. Logarithmically growing cells in sulphate-free minimal medium containing $0.1 \%$ yeast nitrogen base, $2 \%$ glucose, $0.05 \%$

L-asparagine, $0.1 \%$ ammonium chioride and $50 \mu \mathrm{g} / \mathrm{ml} \mathrm{L}$-histidine, were harvested and pulse-labelled for seven minutes with 100 microcuries $35 \mathrm{~s}$ methionine as described in Materials and Methods. After the pulse, $100 \mu \mathrm{g} / \mathrm{ml}$ cycloheximide was added, and a sample ( $0 \mathrm{~min})$ was taken and put on ice. L-methionine was added to $2 \mathrm{mM}$, and samples were taken at $2,5,10,20$, 50 and $100 \mathrm{~min}$. The samples were put in 10\% T.CA on ice until extracted according to Yaffe and Schatz (1984). ( $\mathrm{m}$ ) and ( $p$ ) indicate the mature and precursor forms of beta subunit respectively. 
the chase. In the case of I8 the precursor was partly matured and imported after 10 minutes, and completely after 50 minutes (figure 5.18). In order to test whether the primary effect was on translocation or maturation, a similar experiment should be performed using wild-type beta subunit, and mutants G5 and H2. Both mutants have multiple amino acid substitutions, and are imported into yeast mitochondria in vitro (Chapter 5.2). G5 is similar to I8 in the distribution of amino acid changes, and is not processed during import in vitro. H2 which has a comparable number of substitutions to I8 and G5, that are similarly distributed in the presequence, is transported and processed in vitro.

It can be concluded that mitochondrial transport of beta subunit precursor was not significantly effected by altering the primary sequence of the protein. The mutants were correctly targeted and processed within the mitochondrial matrix. However, an effect on expression and the rate of transport may explain the inability of certain mutants to complement the atp2 lesion. The amounts which are delivered to the mitochondrial matrix and assembled into the ATP synthase complex, at a particular time point, is likely to be insufficient to support the levels of oxidative phosphorylation required by the cell. 
CHAPTER 6. DISCUSSION. 


\section{DISCUSSION.}

There has been considerable interest in determining the features of presequences involved in specific targeting to mitochondria and sorting within the four mitochondrial compartments: the inner and outer membranes, the intermembrane space, and the matrix. How do these 'signals' enable a protein to cross hydrophobic membrane barriers en route to its final destination?

To date, most information has been gained from gene fusion studies using mitochondrial protein presequences attached to non-mitochondrial proteins. Such studies show that as few as 9-12 amino acids of a mitochondrial presequence may be sufficient for directing proteins to the matrix (Keng et al., 1986; Hurt et al., 1985a). Any other sequence feature such as hydrophobic regions may constitute sorting signals (Hurt et al., 1985b).

The beta subunit of mitochondrial ATP synthase was chosen in this study as a model for examining the structural features of targeting signals common to most imported mitochondrial proteins. Beta subunit is one of five nuclear-encoded polypeptides of the F1-ATPase segment: $\left(\alpha_{3}, \beta_{3}, \gamma_{1}, \delta_{1}, \varepsilon_{1}\right)$. In addition, the yeast ATP synthase enzyme is made of an intergral membrane segment Fo (ATPase subunits 6,8 and $9, F 1$ binding protein, and oligomycin sensitivity-conferring protein), which may be partly encoded by the mitochondrial genome. The stoichiometry of this latter segment may resemble its simpler E. coli counterpart $\left(\mathrm{a}_{1}, \mathrm{~b}_{2}, \mathrm{c}_{6}\right)$. A peptide inhibitor $\mathrm{I}$ is suggested to bind with the beta subunit which prevents 
hydrolysis of newly syntheised ATP (Amzel and Pedersen, 1983). The beta and alpha subunits may function as regulatory and catalytic centres in ATP synthesis, which is coupled to proton translocation in the Fo segment (Pedersen and Carafoli, $1987 \mathrm{a}, \mathrm{b})$.

The analysis of the beta subunit precursor protein was approached by gene fusions and mutagenesis in vitro of the corresponding DNA. Gene fusions between the beta subunit of ATP synthase attached to DHFR, a cytosolic protein, showed that the first 15 amino acids of the presequence were sufficient for the delivery of DHFR to the mitochondrion, without processing. When DHFR was fused to the first 35 residues of beta subunit, the efficiency of transport was improved and processing was observed. These results are comparable with those of Emr et al., (1986), who showed that the first 37 amino acids of beta subunit were sufficient to transport the normally secreted protein invertase to mitochondria in vivo, and with those of Vassarotti et al., (1987a), who showed by deletion analysis that the minimal targeting sequence was contained in the first 10 residues of the beta subunit precursor.

Together, the data suggest that the presequence contains more than sufficient information for intracellular sorting of the precursor, as well as proteolytic maturation by the matrix-located endoprotease.

What was the function of the protein sequences between residues 16 and 35 in the beta subunit precursor? Does this sequence carry a second targeting signal or only information for processing? The deletion studies of Vassarotti et al., (1987a) showed that deletions extending from residue 36 towards the 
first 10 amino acids of the presequence did not block transport of the attached mature protein in vivo, unlike a longer deletion between amino acids 5 and 37 . These results should be interpreted with caution, as the size of the deletions were large and the deletions were only made in one direction. Since no attempt was made to analyse small deletions extending from the extreme $\mathrm{N}$-terminus towards the mature protein, the presence of a second targeting signal could not be excluded.

In order to determine whether the beta subunit precursor carried a second targeting sequence, a hybrid protein containing residues $16-35$ of the beta subunit precursor attached to DHFR, was tested for in vitro transport. The protein was transported with greater efficiency as compared with the F1 $\beta_{15}$ DHFR fusion in vitro. Processing was not observed, unlike the fusion containing the entire presequence $\left(\mathrm{F} 1 \beta_{35} \mathrm{DHFR}\right)$.

The structural arrangement of the targeting information contained within the beta subunit precursor polypeptide as two 'signals' or protein domains, appears to be strikingly different from other matrix proteins such as subunit IV of cytochrome $c$ oxidase (Hurt et al., 1985a, 1987) and human ornithine transcarbamylase (Nguyen et al., 1987). In these proteins a single targeting sequence and processing signal were demonstrated to be carried in separate protein domains in the presequence.

The inability of $\mathrm{F}_{1} \beta_{16-35}$ to be processed although the cleavage site between $\operatorname{lys}_{19}$ and $\ln _{20}$ (Vassarotti et al., 1987a) was retained, suggests that information contained between residues 1 and 15 , as well as between residues 23 and 37 reported by Vassarotti et al., (1987a), were required for 
recognition by the matrix endoprotease. Furthermore, processing was not a requisite for assembly into functional ATP synthase.

These data suggest that information for targeting and proteolytic maturation act independently. The matrix protease probably recognises a conformation of the precursor, and that residues proximal and distal to the processing site are important in the interaction of the precursor with this enzyme.

The amino acid requirements within the beta subunit presequence for mitochondrial delivery of the precursor were investigated by mutagenesis in vitro of the ATP2 gene encoding this protein. Most of the amino acid changes in the first 15 residues of the presequence had little or no effect on transport or maturation of attached DHFR in vitro. However, multiple mutations near the cleavage site were found to interfere with transport and/or cleavage of the precursor.

The mutations were examined in the otherwise wild type F1B subunit for transport in vivo and assembly of a functional enzyme complex. Mutant targeting sequences may show a different effect on protein transport depending on the protein attached. Emr et al., (1986) observed that translocation of a hybrid protein containing the beta subunit attached to the $\mathrm{N}$-terminus of $E$. coli beta-galactosidase was less efficient than the corresponding beta subunit-invertase hybrid protein, requiring 169 residues of the mitochondrial protein to direct transport to the mitochondria (which is considerably greater than the twenty amino acid presequence (Vassarotti et al., 1987)). Similar observations were made for the targeting efficiency of F1 $\beta$ subunit when attached to $E$. coli beta-galactosidase rather than the F1ß subunit protein (Vassarotti et al., 1987a). 
A complementation assay was used to screen for functional targeting sequences within the F1p subunit precursor. The atp2 mutant JQ1, which lacked F1ß subunit, was unable to grow on non-fermentable carbon such as glycerol. As the mutated ATP2 genes expressed in the yeast host were unaltered in the mature protein sequence, the transport and assembly of F1 $\beta$ subunit would allow growth on glycerol (the yeast phenotype being $\left.A T P 2^{+}\right)$, whereas cells expressing import defective polypeptides would be unable to grow on glycerol and their phenotype would be atp $2^{-}$. In contrast to these predictions, several yeast transformants expressing mutant presequences which were previously shown to be functional in vitro, possessed a glycerol- phenotype. Experimental data indicated that most of the mutants were expressed at levels comparable with wild type beta subunit. Transport and processing were surprisingly not blocked, although preliminary kinetic studies showed some of the mutants may have been effected in the rate of import and processing.

These experiments showed that correlations between transport and gene complementation cannot be made with certainty. Factors such as the rate of import and assembly of beta subunit into F1ATPase have been shown to be important, at least in vitro (Burns and Lewin, 1986). The imported precursors of $F 1 \alpha, F 1 \beta$ and $F 1 \gamma$ were rapidly assembled with each other, although the rate of import and assembly for beta subunit was slower.In the cell the cytoplasmic pool of beta subunit precursor available for transport, may be in part, dependent on the rate of protein turnover or protein synthesis. A decrease in the availability of the precursor may have resultant effects on 
the import of the polypeptide and assembly of ATP synthase, to the extent that oxidative phosphorylation and therefore growth on glycerol, can not be supported.

Cell fractionation data on the mutant polypeptides expressed in JQ1 showed that import was rapid. No precursor to beta subunit was accumulated in the cytoplasm. However, precursor was found in the mitochondria with certain mutant polypeptides. Further experiments should demonstrate whether these beta subunit precursors are assembled as a functional ATP synthase enzyme.

Pilgrim and Young (1987) recently reported similar effects of mutations made in the presequence of mitochondrial alcohol dehydrogenase ( $A D H$ III) in yeast. Amino acid changes in either the first 14 amino acids of the 28 residue presequence, or residues $31-47$ of the mature protein, had no effect on the rate of import or processing, whilst those near the cleavage site either partially or completely blocked processing.

The N-terminal half of the mitochondrial presequence, at least in the beta subunit of yeast ATP synthase and yeast alcohol dehydrogenase, is remarkably tolerant of amino acid changes, which is unexpected for such a small protein sequence directing transport into the mitochondrion. This is in contrast to findings of Horwich and coworkers (1985), who found that substitution of glycine for an arginine at a single position in the presequence of human ornithine carbamyltransferase, leads to a reduction in transport and processing. However, substitution of the same residue with either lysine, containing a positive charge, or alanine, a nonpolar substitution, restored processing. These observations may be explained by the 
amphiphilic helix model (von Heijne, 1986) which suggests that the import of mitochondrial proteins is in part, mediated by the formation of an amphiphilic helix within the presequence at the membrane surface (Roise et al., 1986; von Heijne, 1986). The glycine residues introduced in the ornithine transcarbamylase presequence are known to disrupt helices, and thus may interupt the targeting information in the presequence, whereas the lysine and alanine residues allow the formation of a stable $\alpha$ helix. The amino acid changes made in the beta subunit presequence either removed proline, which is known to disrupt the helix, ( $\mathrm{pro}_{4}$ to ser or leu) or introduced nonpolar or hydrophobic residues (thr by ile, ser by phe, and ala by val). The residues alanine, phenylalanine, leucine and valine are known to stabilise $\alpha$ helices, whilst isoleucine, serine, and threonine have a tendency to destabilise the structure. These changes are less likely to have gross effects on the secondary structure of the presquence, other than to straighten small bends in the helix or increase its hydrophobicity.

In the model, the amphipathic helix is suggested to act by destabilising the mitochondrial membrane in an energy dependent manner to enable membrane translocation (Schleyer and Neupert, 1985; Roise et al., 1986). Therefore, the extent to which an amphiphilic structure is formed within the presequence may influence the efficiency of membrane translocation. It is of interest to note that the beta subunit precursor may carry two independent targeting signals. These 'signals' may act cooperatively in transport as two $\alpha$ helices, as suggested by the gene fusion and in vitro mutagenesis studies. This interpretation is in good agreement with the proposal by 
Vassarotti et al., (1987b), which is based on secondary structure predictions made by amphipathic analysis of the first 100 residues (Finer-More and Stroud,(1984). These residues were suggested to exist in aqueous solution as a folded structure containing four helices; I (1-21), II (24-37), III (51-73) and IV $(76-100)$. The interaction of the precursor with the lipid membrane may cause the first two helicies to lie on the surface of the membrane, and straighten the bend due to proline ${ }_{2}$ to give an extended single helix, which would then mediate membrane translocation of the rest of the protein.

In the last few years, the research into the import of mitochondrial proteins has shown that the information required for intracellular sorting of mitochondrial proteins is contained within the $\mathrm{N}$-terminal presequence (Hurt and van Loon, 1986). The information being retained as a basic amphiphilic helix (von Heijne, 1986). The question arises as to how these presequences evolved? Several studies have recently addressed this question. The high tolerance of amino acid changes in mitochondrial presequences and lack of sequence homology between different mitochondrial proteins, or a particular protein between species, suggests that mitochondrial presequences may have arisen by point mutations in the $5^{\circ}$ sequence of the corresponding gene. The beta subunit protein is highly conserved and shows a high degree of sequence homology (70\%) between species (Wallace et al., 1987). However, its presequence varies in size and amino acid sequence from twenty amino acids in yeast (Vassarotti et al., 1987a) to sixty amino acids in man (Ohta and Kagawa, 1986). Stronger evidence has come from recent 
studies by Vassarotti et al., (1987b) on F1 $\beta$ subunit, who demonstrated that mutations in the extreme $\mathrm{N}$-terminus of a truncated beta subunit precursor restored transport in vivo. These mutations gave rise to amino acid changes favouring neutral or basic amino acids.

There is also considerable evidence which supports the view that presequences arose from gene rearrangements. DNA sequences from the $E$. coli genome or structural gene for mouse DHFR were found to act as targeting 'signals' when attached to a truncated mitochondrial protein, and direct transport into mitochondria in vivo. These sequences occurred at a high frequency of $2-5 \%$ and resembled natural mitochondrial presequences in the abundance of basic and hydroxylated amino acids and deficiency of acidic ones (Baker and Schatz, 1987).

This study has begun to define the structural requirements within the presequence for delivery of the beta subunit precursor to the mitochondrion. The precursor polypeptide contains two targeting sequences; the first in the $\mathrm{N}$-terminal 15 amino acid residues is highly tolerant of mutations. Whether the first signal is dispensible in the precursor in vivo, raises interesting questions as to why there are two targeting sequences. One explanation may be that the beta subunit presequence arose from two tandem gene rearrangements resulting in duplication of the targeting information. Specific amino acid changes could be introduced by site directed mutagenesis in vitro within the second targeting sequence to give further insights into the import pathway. These studies would include kinetic experiments on the rate of import and processing, and assay of ATP synthase activity with respect to ATP synthesis and 
proton translocation. Other studies may include isolation and purification of wild type and mutant polypeptides from the cytosol and mitochondria for biochemical and biophysical studies which could demonstrate the conformational changes that the protein may undergo during the transport process.

The future goals are likely to concern the isolation and characterisation of the transport machinery involved in mitochondrial protein transport; with the possible isolation of mutants such as those for the exocytic and endocytic pathways (Schekman, 1982; Riezman 1985). As of yet, only two such mutants have been characterised which are involved in proteolytic maturation of a few imported mitochondrial proteins. The problems which will be faced by the researcher are that of a limited understanding of the types of interaction which must take place between the nucleus and mitochondria during mitochondrial biogenesis, such as the transport of solutes, and regulatory factors, as well as a diversity of import and processing pathways for uptake of nuclear encoded proteins into the mitochondrion. 



\section{REFERENCES}

Ades, I. Z., \& R. A. Butow (1980) J. Biol. Chem. 255, 9925-9935. Adrian, G. S., McCammon, M. T., Montgomery, D. L., \& M. G. Douglas (1986) Mol. Cell. Biol. 6(2), 625-634.

Ainger, K. J., \& D. I. Meyer (1986) EMBO J. 5(5), 951-955.

Albright, C., \& P.W. Robbins (1986) 13th Int. Conf. Yeast Gen. Mol. Biol., Banff. Abst. S5.

Allison, D. S., \& G. Schatz (1986) Proc. Natl. Acad. Sci. 83, 9011-9015.

*

Anderson, S., Bankier, A. T., Barrell, B. G., de Brijn, M. H. L., Coulson, A. R., Drovin, J., Eperon, I. C., Nierlich, D. P., Roe, B. A., Sanger, F., Schreier, P. H., Smith, A. J. H., Staden, R., \& I. G. Young (1981) Nature 290, 457-465.

Andrews, T., (1983) J. Dairy Res. 50, 45-55.

Argan, C., Lusty, C. T., \& G. C. Shore (1983) J. Biol Chem. 258, 4071-4074.

Baker, A., \& G. Schatz (1987) Proc. Natl. Acad. Sci. 84, 3117-3121.

Bankaitis, V. A., Johnson, L. M. , \& S. D. Emr (1986) Proc. Natl. Acad. Sci. 83, 9075-9079.

Behra, R., \& P. Christen (1986) J. Biol. Chem. 261(1), 257-263.

Birmboim, H. C., \& J. Doly (1979) Nuc. Acids Res. 7, 1513-1523.

Blobel, G., B. Dobberstein (1975a) J. Cell. Biol. 67, 835-851.

Blobel, G., \& B. Dobberstein (1975b) J. Cell. Biol. 75, 852-862.

Blobel, G., (1980) Proc. Natl. Acad. Sci. 77, 1496-1500.

Boehni, P. C., Daum, D., \& G. Schatz (1983) J. Biol. Chem. 258, 4937-4943.

Bonner, W. M. , (1975a) J. Cell. Biol. 64, 421-430.

Bonner, W. M., (1975b) J. Cell. Biol. 64, 431-437.

Breitenberger, C. A., \& U. L. RajBhandary (1985) Trends Biochem. Sci. 10(12), 479-483.

Burns, D. J., \& A. S. Lewin (1986) J. Biol. Chem. 261(26), 12066-12077.

* Amzel, L.M., \& P. L. Pedersen (1983) Ann. Rev. Biochem. 52:801-24. 
Butel, J. S., Guentzel, M. J., \& F. Rapp (1969) J. Virol. 4, 632-641.

Butler, E. T., \& M. J. Chamberlin (1982) J. Biol. Chem., 258, (8) $4937-4943$.

Chien, S. M., Patel, H. V., \& K. B. Freeman (1984) J. Cell. Biol. 259, 13633-13636.

Chien, S. M. , \& K. B. Freeman (1986) Biochem. Biophys. Res. Commun. 141(1), 313-318.

Chen, L., \& P. C. Tai (1985) Proc. Natl. Acad. Sci. 82, 4384-4388.

Chen, W-J., \& M. G. Douglas (1987) Cell 49, 651-658.

Chevallier, M-R., Bloch, J-C., \& F. Lacroute (1980) Gene 11, 11-19.

Crimaudo, C., Hortsch, M., Gausephol, H., \& D. I. Meyer (1987) EMBO J. 6(1), 75-82.

Daum, G., Boehni, P. C., \& G. Schatz (1982) J. Biol. Chem. 257(21), 13028-13033.

De Robertis, E. M., (1983) Cell 32, 1021-1025.

Desautes, M., \& A. L. Goldberg (1982) J. Biol. Chem. 257, 11673-11679.

Dieckmann, C. L., Koerner, T. J., \& A. Tzagaloff (1984) J. Biol. Chem. 259, 4722-4731.

Dieckmann, C. L., \& A. Tzagaloff (1985) J. Biol. Chem. 260 (3), 1513-1519.

Dingwall, C., Sharnick, S. V., \& R. A. Laskey (1982) Cell 30, 449-458.

Dingwall, C., (1985) Trends. Biochem. Sci. 10(2), 64-66.

Dingwall, C., Dilworth, S. M., Black, S. J., Kearsey, S. E., Cox, L. S., \& R. A. Laskey (1987) EMBO J. 6(1), 69-74.

Douglas, M. G., \& M. Takeda (1985) Trends Biochem. Sci. 10 (5), 192-194.

Eilers, M., \& G. Schatz (1986) Nature 322, 228-232.

Eilers, M., Oppliger, W., \& G. Schatz (1987) EMBO J. 6(4), 1073-1077.

Ellis, R. J., Smith, S. M., \& R. Barraclough (1980) in Genome organization and expression in plants, C. J. Leaver, ed. , 321-35, Plenum, New York. 
Emr, S. D. , \& T. J. Silhavy (1982) J. Cell. Biol. 95, 689-696.

Emr, S. D., \& T. J. Silhavy (1983) Proc. Natl. Acad. Sci. 80, 4599-4603.

Emr, S. D., Schauer, I., Hansen, W., Esmon, P., \& R. Schekman (1984) Mol. Cell. Biol. 4(11), 2347-2355.

*

Epand, R. M., Hui, S. W., Argan, C., Gillespie, L. L., \& G. C. Shore (1986) J. Biol. Chem. 261, 10017-10020.

Evans, E. A., Gilmore, R., \& G. Blobel (1986) Proc. Natl. Acad. Sci. 83, 581-585.

Farquhar, M. G., \& G. E. Palade (1981) J. Cell. Biol. 91, 77-103.

Finer-Moore, J., \& R. M. Stroud (1984) Proc. Natl. Acad. 81, 115-159.

Firgaira, F. A., Hendrick, J.P., Kalousek, F., Kraus, J. P., \& L. E. Rosenberg (1984) Science 226, 1319-1322.

Foster, D. L. \& R. H. Fillingame (1979) J. Biol. Chem. 254, 8230-8236.

Gascuel, O., \& A. Danchin (1986) J. Mol. Biol. 24, 130-142.

Gasser, S. M., Ohashi, A., Daum, G., Boehni, P. C., Gibson, J., Reid, G. A., Yonetani, T., \& G. Schatz (1982a) Proc. Natl. Acad. Sci. 79, 267-271.

Gasser, S. M., Daum, G. , \& G. Schatz (1982b) J. Biol. Chem. 257, 13034-13041.

Geller, B. L., Movva, N. R., \& W. Whicker (1986) Proc. Natl. Acad. Sci. 83, 4219-4222.

Gilmore, R., Walter, P., \& G. Blobel (1982) J. Cell. Biol. 95, 470-477.

Grivell, L. A. (1983) Scientific American 248, 60-73.

Grossman, A., Bartlett, S., \& N-H Chua (1980) Nature 285, 625-628.

Guan, J-L., \& J. K. Rose (1984) Cell 37, 779-787.

Guarente, L., \& T. Mason (1983) Cell 32, 1276-86.

Guiard, B., (1985) EMBO J. 4(12), 3265-3272.

Hagman, J., Robinson, C., Smeekens, S., \& P. Weisbeek (1986) Nature $324,567-569$.

Hall, M. N., Hereford, L., \& I. Herekowitz (1984) Cell 36, 1057-1065

Hallermeyer, G., Zimmerman, R., \& W. Neupert (1977) Eur. J. Biochem. 81, 523-532.

Hampsey, D. M. , Lewin, A. S., \& G. B. Kohlaw (1983) Proc. Natl. Acad. Sci. 80, 1270.

* Emr, S.D., vassarotti, A., Garett, J., Geller, B.L., Takeda, M., \& M.G. Douglas (1986) J.Cell Biol. 102: 523-33. 111 
Hartl, F-U., Schmidt, B., Wachter, E., Weiss, H., \& W. Neupert (1986) Cell 47, 939-951.

Hase, T., Riezman, H., Suda, K., \& G. Schatz (1983) EMBO J. 2(12) 2169-2172.

Hase, T., Muller, U., Riezman, H., \& G. Schatz (1984) EMBO J. 3(13), 3157-3164.

Hay, R., Boehni, P., \& S. Gasser (1984) Biochim. Biophys. Acta. 779, 65-87.

Hennig, B., \& W. Neupert (1981) Eur. J. Biochem. 121, 203-212.

Hortsch, M., \& D. Meyer (1984) Biol. Cell. 52, 1-8.

Horwich, A. L., Kalousek, F., Mellman, I., \& L. E. Rosenberg (1985a) EMBO J. 4(5), 1129-1135.

Horwich, A. L., Kalousek, F., \& L. E. Rosenberg (1985b) Proc. Natl. Acad. Sci. 82, 4930-4933.

Horwich, A. L., Kalousek, F., Fenton, W. A., Pollock, R. A., \& L. E. Rosenberg (1986) Cell 44, 451-459.

Hurt, E. C., Pesold-Hurt, B., \& G. Schatz (1984) EMBO J. 3(13), 3149-3156.

Hurt, E. C., Pesold-Hurt, B., Suda, K., Opplinger, W., \& G. Schatz (1985a) EMBO J. 4(8), 2061-2068.

Hurt, E. C., Muller, U., \& G. Schatz (1985b) EMBO J. 4 (13A), 3509-3518.

Hurt, E. C., Soltanifar, Goldschmidt-Clermont, M., Rochaix, J-D., \& G. Schatz (1986a) EMBO J. 5(6), 1343-1350.

Hurt, E. C., Goldschmidt-Clermont, M., Pesold-Hurt, B., Rochaix, J-D. , \& G. Schatz (1986b) J. Biol. Chem. 261(25), 11440-11443.

Hurt, E. C. , \& A. P. G. M. van Loon (1986) Trends Biochem. Sci. 11, 204-207.

Hurt, E. C., Allison, D. S., Muller, U., \& G. Schatz (1987) J. Biol. Chem. 262(3), 1420-1424.

Hurt, E. C., \& G. Schatz (1987) Nature 325(6104), 499-503.

Ito, H., Fukuda, Y., Murata, K., \& K. Kimura (1983) J. Bacteriol. 153(1), 163-168.

Ito, A., Ogishima, T., Ou, W., Omura, T., Aoyagi, H., Lee, S., Mihara, H., \& N. Izumiya (1985) J. Biochem. 98, 1571-1582.

Johnson, L. M., \& V. A. Bankaitis (1987) Cell 48, 875-885.

\& S.D. Emr 
Kaiser, C. A., Preuss, D., Grisafi, P., \& D. Botstein (1987) Science $235,312-317$.

Kalderon, D., Oostra, B. A., Ely, B. K., \& A. E. Smith (1982) Nuc. Acids Res. 10, 5161-5171.

Karlin-Neumann, G. A., \& E. M. Tobin (1986) EMBO J. 5 (1), 9-13.

Kellems, R. E., Allison, V. F., \& R. A. Butow (1974) J. Biol. Chem. 249, 3297-3303.

Kellems, R. E., Allison, V. F., \& R. A. Butow (1975) J. Cell. Biol. $65,1-14$.

Kelly, R. B., (1987) Nature $326,14-15$.

Keng, T., Alani, E., \& L. Guarente (1986) Mol. Cell. Biol. 6(2), $355-364$.

Klingenberg, M. , \& H. Rottenberg (1977) Eur. J. Biochem. 73, 125.

Korb, H., \& W. Neupert (1978) Eur. J. Biochem. 91, 609-620.

Krieg, P.A. \& D. A. Melton (1984) Nuc. Acids Res. 12(18), 7057-7070.

Krieg, U. C., Walter, P., \& A. E. Johnson (1986) Proc. Natl. Acad. Sci. $83,8604-8608$.

Kuhn, A., Wicker, W., \& G. Kreil (1986) Nature 322, 355-339.

Langford, R. E., \& J. S. Butel (1984) Cell 37, 801-813.

Langford, R. E., \& Kanada, P., \& R. C. Kennedy (1986) Cell 46, 801-813.

Lewin, A. S., \& D. K. Norman (1983) J. Biol. Chem. 258, 6750-6755.

Lindahl, T. (1982) Ann. Rev. Biochem. 51, 61-87.

Lonsdale, D. M. , Hodge, T. P., \& C. M. R. Fauron (1984) Nuc. Acids. Res. $12(24), 9249-61$.

Lukins, H. B., Devenish, R. J., \& A. W. Linnane (1984) Microbiol. Sci. $1(6), 141-149$.

Lunn, C.A., \& M. Inouye (1987) J. Biol. Chem. 262(17), 8318-8324.

Maccecchini, M., Rudin, Y., Blobel, G., \& G. Schatz (1979) Proc. Natl. Acad. Sci. 76, 343-347.

Mandel, M., \& A. Higa (1970) J. Mol. Biol. 53, 154.

Maniatis, T., Fritsch, E. F., \& J. Sambrook (1982) in Molecular Cloning - A Laboratory Manual, 8th printing, Cold Spring Habor Laboratory.

Matsuura, S., Arpin, M., Hannum, C., Margoliash, E., Sabatini, D. D., \& T. Morimoto (1981) Proc. Natl. Acad. Sci. 78(7), 4368-4372. 
Matto, A. K., \& M. Edelman (1987) Proc. Natl. Acad. Sci. 84, 1497-1501.

McAda, P.C., \& M. G. Douglas (1982) J. Biol. Chem. 257, 3177-3182.

McKnight, G. L., \& B. L. McConaughty (1983) Proc. Natl. Acad. Sci. $80,4411-4416$.

Melton, D. A., Krieg, P., \& M. R. Green (1984) Nuc. Acids Res. 12(18), 7035-7056.

Meyer, D. I., Krause, E., \& B. Dobberstein (1982) Nature 297, 647-650.

Meyer, D. I. (1985) EMBO J. 4, 2031-2033.

Mishkind, M. L., Jensen, K. H., Branagan, A. J., Plumley, F. G., \& G. W. Schmidt (1985) Curr. Top. Plant Biochem. Physiol. 4, 34-50.

Miura, S., Mori, M. , Amaya, Y., \& M. Tabitana (1982) Eur. J. Biochem. $122,641-647$.

Miura, S., Amaya, Y., \& M. Mori (1986) Biochem. Biophys. Res. Commun. 134(3), 1151-1159.

Moreland, R. B., Nam, H-G., Hereford, L. M., \& H. M. Fried (1985) Proc. Natl. Acad. Sci. 82, 6561-6565.

Mori, M., Miura, S., Tabitana, M., \& P. P. Cohen (1980) Proc. Natl. Acad. Sci. 77, 7044-7048.

Mueckler, M. , \& H. F. Lodisch (1986) Cell 44, 629-637.

Munro, S., \& H. R. B. Pelham (1987) Cell 48, 899-907.

Neupert, W., \& G. Schatz (1981) Trends. Biochem. Sci. 6, 1-4.

Nguyen, M., Argan, C., Sheffield, W. P., Bell, A. W., Shields, D., \& G. C. Shore (1987) J. Cell. Biol. 104, 1193-1198.

Novick, P., S. Ferro, \& R. Schekman (1981) Cell 25, 461-469.

Ohashi, A., Gibson, J., Gregor, I., \& G. Schatz (1982) J. Biol. Chem. 257, 13042-13047.

Ohta, S., \& Y. Kagawa (1986) J. Biochem. 99, 135-141.

Ohta, S., G. Schatz (1984) EMBO J. 3, 651-657.

Ono, H., \& A. Ito (1984a) J. Biochem. 95, 345-352.

Ono, H., \& A. Ito (1984b) J. Biochem. 95,353-358.

Orci, L., Ravazzala, M., \& R. G. W. Andersen (1987) Nature 326, $77-79$.

Ou, W. , Ito, A., Morohashi, K-I., Fuji-Kuriyama, Y., \& T. Omura (1986) J. Biochem. 100, 1287-1296. 
Paine, P. L., Moore, L. C., \& S. B. Horowitz (1975) Nature 254, 109-114.

Parikh, V. S., Morgan, M. M., Scott, R., \& L. Scott-Clements, \& R. A. Butow (1987) Science 235, 576-580.

Parsonage, D., Wilke-Mounts, S., \& A. E. Senior (1987) J. Biol. Chem. 262(17), 8022-8026.

Pedersen, P. L., \& E. Carafoli (1987a) Trends. Biochem. Sci. 12, 146-150.

Pedersen, P. L., \& E. Carafoli (1987b) Trends. Biochem. Sci. 12, 186-192.

Pelham, H. R. B., \& A. J. Jackson (1976) Eur. J. Biochem. 67, 247-256.

Pfanner, N. , \& W. Neupert (1985) EMBO J. 4(11), 2819-2825.

Pfanner, N., \& W. Neupert (1986) FEBS lett. 209(2), 152-156.

Pilgrim, D., \& E. T. Young (1987) Mol. Cell. Biol. 7(1), 294-304.

Pratje, E., \& B. Guiard (1986) EMBO J. 5(6), 1313-1317.

Prehn, S., Wiedmann, M., Rapport, T. A., \& C. Zwieb (1987) EMBO J. $6(7)$, 2093-2097.

Reid, G. A., \& G. Schatz (1982a) J. Biol. Chem. 257(21), 13056-13061. Reid, G. A., \& G. Scahtz (1982b) J. Biol. Chem. 257(21), 13062-13067.

Reid, G. A., (1985) Curr. Top. Mem. Transp. 24, 295-333.

Reidel, N., \& H. Fasold (1987) Biochem. J. 241, 213-219.

Richardson, W. D., Roberts, B. L., \& A. E. Smith (1986) Cell 44, 77-85.

Riezman, H., Hay, R., Witte, C., Nelson, N., \& G. Schatz (1983) EMBO J. 2, 1113-1118.

Riezman, H., (1985) Cell 40, 1001-1009.

Roberts, B. E., \& B. M. Paterson (1973) Proc. Natl. Acad. Sci. 70, 2330-2334.

Robinson, C., \& R. J. Ellis (1984) Eur. J. Biochem. 142,337-342.

Roise, D., Horvath, S. J., Tomich, J. M., Richards, J. H., \& G. Schatz (1986) EMBO J. 5(6), 1327-1334.

Rothblatt, J. A., \& D. I. Meyer (1986) Cell 44, 619-628.

Rothman, J. H., \& T. H. Stevens (1986) Cell 47, 1041-1051. 
Sabatini, D. D., Tashiro, Y., \& G. E. Palade (1966) J. Mol. Biol. 19, 503-524.

Sadler, I., Suda, K., Schatz, G., Kaudewitz, F., \& A. Haid (1984) EMBO J. 3(9), 2137-2143.

Saltzgaber-Muller, J., Kunapuli, S., \& M. G. Douglas (1983) J. Biol. Chem. 258, 11456-11470.

Sanger, F., Nicklen, S., \& A. Coulsen (1977) Proc. Natl. Acad. Sci. $74,5463-5467$.

Schatz, G., \& T. L. Mason (1974) Ann. Rev. Biochem. 43, 51-87.

Schatz, G., (1987) Eur. J. Biochem. 165, 1-6.

Schleyer, M., Schmidt, B., \& W. Neupert (1982) Eur. J. Biochem. 125, 109-116.

Schleyer, M. , \& W. Neupert (1985) Cell 43, 339-350.

Schmidt, B., Wachter, E., Sebald, W., \& W. Neupert (1984) Eur. J. Biochem. 144, 581-588.

Schmidt, G. W., \& M. L. Mishkind (1986) Ann. Rev. Biochem. 55, 879-912.

Schekman, R., (1982) Trend. Biochem. Sci. 7(7), 243-246.

Shortle, D., \& D. Nathans (1978) Proc. Natl. Acad. Sci. 75, 2170-2174.

Silver, P., A., Keegan, L. P., \& M. Ptashne (1984) Proc. Natl. Acad. Sci. $81,5951-5955$.

Sivasubramanian, N., ,\& D. P. Nayak (1987) Proc. Natl. Acad. Sci. 84, 1-5.

Sly, W. S., \& H. D. Fischer (1982) J. Cell. Biochem. 18, 67-85.

Smith, R. III., Huston, M. M., Jenkins, R. N., Huston, D. P., \& R. R. Rich (1983) Nature 306, 599-601.

Stevens, T., Esmon, B., \& R. Schekman (1982) Cell 30, 439-448.

Stueber, D., Ibramhimi, I., Cutler, D., Dobberstein, B., \& H. Bujard (1984) EMBO J. 3 (13), 3143-1348.

Suissa, M. , \& G. Schatz (1982) J. Biol. Chem. 255, 13048-13055.

Swanson, M. S., Ziemann, S. M., Miller, D. D., Garber, E. A. E., \& E. Margoliash (1985) Proc. Natl. Acad. Sci. 82, 1964-1968.

Szekely, E., \& D. Montgomery (1984) Mol. Cell. Biol. 4, 939-946.

Takahara, M., Hibler, D. W., Barr, P. J., Gerlt, J. A., \& M. Inouye (1985) J. Biol. Chem. 260, 2670-2674. 
Takeda, M., Vassarotti, A., \& M. G. Douglas (1985) J. Biol. Chem. $260(29), 15458-15465$.

Takeda, M., Vassarotti, A., \& M. G. Douglas (1986) J. Biol. Chem. 261(22), 10466.

Tamm. L. K., (1986) Biochem. 25, 7470-7476.

Tzagaloff, A., (1975) in Membrane Biogenesis, 1-4, Plenum, New York.

Tzagaloff, A., \& A. M. Meyers (1986) Ann. Rev. Biochem. 55, 249-285.

Tzagaloff, A., Wu, M., \& M. Crivellone (1986) J. Biol. Chem. 261(36), 17163-17169.

van Loon, A. P. G. M., Maarse, A. C., Riezman, H., \& L. Grivell (1983) Gene 26, 261-272.

van Loon, A. P. G. M., Brandli, A. W. , \& G. Schatz (1986) Cell 44, 801-812.

van Loon, A. P. G. M., Brandli, A. W., Pesold-Hurt, B., Blank, D., \& G. Schatz (1987) EMBO J. 6(8), 2433-2439.

van Loon, A. P. G. M., \& G. Schatz (1987) EMBO J. 6(8), 2441-2448.

van Steeg, H., Oudshoorn, P., van Hell, B., Polman, J. E. M. \& L. A. Grivell (1986) EMBO J. 5(13), 3643-3650.

Vassarotti, A., Chen, W-J., Smagula, C., \& M. G. Douglas (1987a) J. Biol. Chem. 262(1), 411-418.

Vassarotti, A., Stroud, R., \& M. Douglas (1987b) EMBO J. 6(3), 705-711.

Verner, K., \& G. Schatz (1987) EMBO J. 6(8), 2449-2456.

Vernet, T., Dignard, D., \& D. V. Thomas (1987) Gene 52(2-3), 225-233.

Viard, I., \& J. C. Stahl (1985) FEBS lett. 180(1), 117-121.

von Heijne, G., (1983) Eur. J. Biochem. 133, 17-21.

von Heijne, G., (1985) J. Mol. Biol. 184, 99-105.

von Heijne, G., (1986) EMBO J. 5(6), 1335-1342.

Wallace, R. B., Johnson, M. J., Suggs, S. V., Miyoshi, K., Blatt, R. , \& K. Itakura (1981) Gene 16, 21-26.

Wallace, D. C., Ye, J., Neckelman, S. N., Singh, G., Webster, K. A., \& B. D. Greenberg (1987) Curr. Genet. 12, 81-90.

Walter, P., \& G. Blobel (1981) J. Cell. Biol. 91, 557-561. 
Waters, M.G., \& G. Blobel (1986) J. Cell Biol. 102, 1543-1550.

Waters, M. G., Chirico, W. J., \& G. Blobel (1986) J. Cell. Biol. 103(6), 2629-2636.

Wickner, W. T., \& H. F. Lodish (1985) Science 230, 400-407.

Yaffe, M. P., \& G. Schatz (1984) Proc. Natl. Acad. Sci. 81, 4819-4823.

Yaffe, M. P., Ohta, S., \& G. Schatz (1985) EMBO J. 4(8), 2069-2074.

Yamane, K., Ichihara, S., \& S. Mizushima (1987) J. Biol. Chem. 262(5) , 2358-2362.

Yasuhara, T., \& A. Ohashi (1987) Biochem. Biophys. Res. Commun. 144(1), 277-283.

Yoshida, Y., Hashimoto, T., Kimura, H., Sakakibara, S., \& K. Tagawa (1985) Biochem. Biophys. Res. Commun. 128, 775-780.

Zeller, R., Nijffenegger, T., \& E. M. De Robertis (1983) Cell 32, 425-434.

Zwizinski, C., Schleyer, M. , \& W. Neupert (1983) J. Biol. Chem. 258, 4071-4074. 